“PANORAMA DO MEIO AMBIENTE NO ESTADO DO MARANHÃO E ALTERNATIVAS PARA MINIMIZAR OS IMPACTOS CAUSADOS AO LONGO DOS ANOS"

\title{
COLETÂNEA DO I FÓRUM DE MEIO AMBIENTE DO ESTADO DO MARANHÃO
}

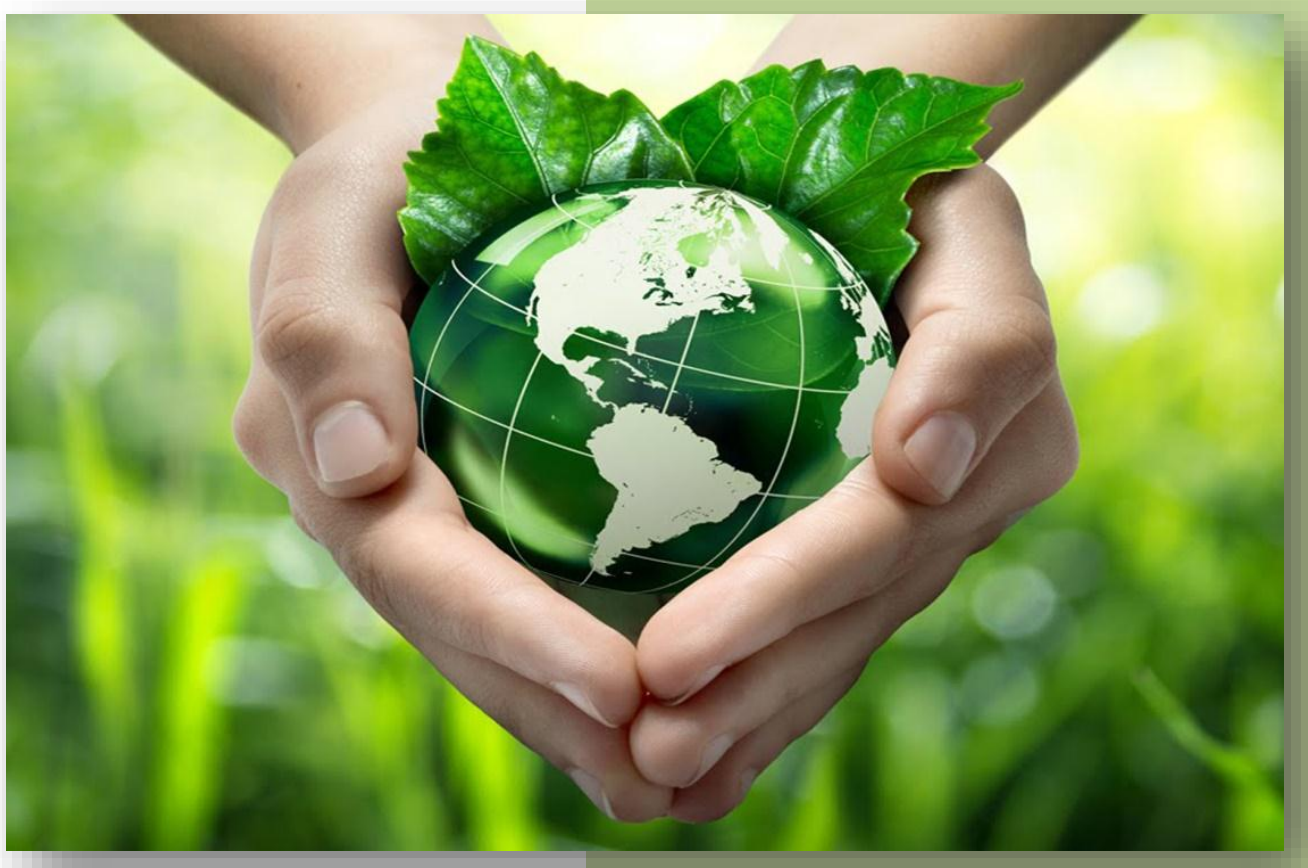

\section{Organizadores}

Fabrício Brito Silva

Helena Ribeiro Sousa

Rita de Cássia Mendonça de Miranda

São Luís, MA 


\section{UNIVERSIDADE CEUMA \\ PRÓ-REITORIA DE PÓS-GRADUAÇÃO PESQUISA E EXTENSÃO MESTRADO EM MEIO AMBIENTE}

Copyright $@ 2019$ UNIVERSIDADE CEUMA

\section{REITOR}

Saulo Henrique Brito Matos Martins

\author{
PRÓ-REITOR DE PÓS-GRADUAÇÃO, \\ PESQUISA E EXTENSÃO \\ Valério Monteiro Neto
}

PRÓ-REITORA DE GRADUAÇÃO

Aline Mendonça da Silva

\section{COORDENADOR DO MESTRADO EM MEIO AMBIENTE \\ Fabrício Brito Silva}

\author{
COORDENADORA DO I FÓRUM DE MEIO \\ AMBIENTE DO ESTADO DO MARANHÃO \\ Rita de Cássia Mendonça de Miranda
}

COMISSÃO CIENTÍFICA
Angela Falcai

Delmo Mattos da Silva

Denilson da Silva Bezerra

Fabrício Brito Silva

Julliana Ribeiro Alves dos Santos

Maria Cláudia Golçalves

Maria Raimunda Chagas Silva

Paulo Cesar Mendes Villis

Rita de Cássia Mendonça de Miranda

Silvio Gomes Monteiro

Wolia Costa Gomes

Dados Internacionais de Catalogação na Publicação (UNICEUMA) Universidade Ceuma Processamento técnico Catalogação na fonte elaborada pela equipe de Bibliotecárias: Gleice Melo da Silva - CRB 13/650

Luciane de Jesus Silva e Silva Cabral - CRB 13/629

Michele Alves da Silva - CRB 13/601

Verônica de Sousa Santos Alves - CRB 13/621

C694

Coletânea do I Fórum de Meio Ambiente do Estado do Maranhão: panorama do Meio Ambiente no estado do Maranhão e alternativas para minimizar os impactos causados ao longo dos anos. [Recurso Eletrônico] / organizadores, Fabrício Brito Silva, Helena Ribeiro Sousa, Rita de Cássia Mendonça de Miranda. / . São Luís: UNICEUMA, 2019.

$126 \mathrm{p}$.

ISBN 978-85-7262-042-0

DOI: https://dx.doi.org/10.24863/978-85-7262-042-0

1. Meio Ambiente. 2. Impactos Ambientais. 3. Maranhão. I. Silva, Fabrício Brito. Sousa, Helena Ribeiro. II. Miranda, Rita de Cássia Mendonça de. III. Título. 


\section{SUMÁRIO}

APRESENTAÇÃO.

6.

CAPÍTULO 1

ANÁLISE DE FOCOS DE QUEIMADAS NO MARANHÃO DURANTE

EVENTOS DE SECA DE 2010 A 2016

7.

Denilson da Silva Bezerra

Liene S. Pereira

Viviane de Gomes Brito

Raoni B. Tomaz

\section{CAPÍTULO 2}

ISOLAMENTO DE MICRORGANISMOS DE INTERESSE

BIOTECNOLÓGICO ORIUNDOS DE ÁREAS CONTAMINADAS COM

AGROQUÍMICO.

Mariana Santos Costa

Thalison Rômulo Rocha Araújo

Ábia de Jesus Martins

Queren Hapuque Sousa da Silva

Celso Henrique Costa

Rita de Cássia Mendonça de Miranda

\section{CAPÍTULO 3}

AGROTÓXICOS NO MARANHÃO E A RESPONSABILIZAÇÃO POR

DANOS À SAÚDE.

Claudson Santos Gomes

Dagolberto Calazans Araujo Pereira

\section{CAPÍTULO 4}

ANÁLISE DE TOXICIDADE DE EFLUENTES GERADOS NA

ATIVIDADE DA CARCINICULTURA NA CIDADE DE BACABEIRAS-

MA

40.

Wellington de Sousa Monteles

Ábia de Jesus Martins

Queren Hapuque da Silva Costa

Thayná Fernandes Barros

Rita de Cássia Mendonça de Miranda

Luís Cláudio Nascimento da Silva

\section{CAPÍTULO 5}

PREVALÊNCIA DA SENSIBILIZAÇÃO DE PACIENTES ASMÁTICOS

POR ALÉRGENOS AMBIENTAIS DERIVADOS DO

DERMATOPHAGOIDES PTERONISSYNUS E BLOMIA TROPICHALIS.

lêda Maria Silva Araújo

Giselmo Pinheiro Lopes

Poliana Oliveira Lemos de Brito

Caroline Zilma Kalil de Paula Costa Pereira

Maryângela Godinho Pereira Bena

Angela Falcai 


\section{CAPÍTULO 6}

RESISTÊNCIA CRUZADA ENTRE AGROTÓXICOS E ANTIFÚNGICOS

DE USO CLÍNICO

Letícia Chagas da Silva

lone Cristine Silva de Araújo

Alessandra Teixeira de Macedo

Joice Castelo Branco Santos

Julliana Ribeiro Alves dos Santos

\section{CAPÍTULO 7}

SÍNTESE, CARACTERIZAÇÃO MOLECULAR E AVALIAÇÃO DA

ATIVIDADE ANTIMICROBIANA DO TRIAZENO 1,3-BIS(2-METOXI-5-

NITROFENIL) TRIAZENO.

Jose Costa Sampaio Filho

Ingrid Santos Gonçalves

Erima Joyssielly Mendonça Castro

Sielys dos Santos Amaral

Rodrigo Vieira Blasques

Luís Felipe Diniz Pereira

Rita de Cassia Mendonça de Miranda

Patrícia de Maria Silva Figueiredo

Paulo Cesar Mendes Villis

\section{CAPÍTULO 8}

ANÁLISE HIDROLÓGICA SUPERFICIAL DA BACIA DO RIO CURUÇÁ COM URBANIZAÇÃO SUSTENTÁVEL DE TRECHO EM PAÇO DO

LUMIAR - MA.

Neemias Muniz de Souza

Wanderson Pedro Oliveira

Rita de Cássia Mendonça de Miranda

Maria Raimunda Chagas Silva

\section{CAPÍTULO 9}

FREQUÊNCIA DE DOR MUSCULOESQUELÉTICA EM ESTUDANTES DE ODONTOLOGIA - ESTUDO PILOTO

Bruna Katarine Beserra Paz

Ariane França Garcês

Miguel Jânio Costa Ferreira

Guilherme Gonçalves Silva

Maria Claudia Gonçalves

\section{CAPÍTULO 10}

AVALIAÇÃO DOSIMÉTRICA DE EXPOSIÇÃO OCUPCIONAL EM

MEDICINA NUCLEAR.

Elsom José Gomes Santos

Alessandra Sampaio Couto

Wolia Costa Gomes 


\section{CAPÍTULO 11}

PREVALÊNCIA DE SENSIBILIZAÇÃO DOS ALÉRGENOS

AMBIENTAIS, BLATELLA GERMÂNNICA E PERIPLANETA

AMERICANA EM PACIENTES ASMÁTICOS

Maryângela Godinho Pereira Bena

Giselmo Pinheiro Lopes

João Lucas do Carmo Lima

Poliana Oliveira Lemos de Brito

Bruna Katarine Beserra Paz

Angela Falcai

SOBRE OS AUTORES 


\section{APRESENTAÇÃO \\ Mensagem da Coordenação do Fórum}

Esta coletânea está organizada em capítulos e compila trabalhos completos apresentados pelos docentes e respectivos discentes, matriculados no Mestrado em Meio Ambiente, além de alunos de Iniciação Científica de diversos cursos de graduação da Universidade Ceuma. Os trabalhos foram apresentados durante 0 I Fórum de Meio Ambiente do Estado do Maranhão, que ocorreu nos dias 31 de maio a 02 de junho de 2017 na Universidade Ceuma. Estão aqui apresentados onze artigos que discutem Saúde, Meio Ambiente e Sustentabilidade, cuja temática aborda desde danos das queimadas na Amazônia, passando pelos prejuízos dos agrotóxicos ao meio ambiente e à saúde humana até questão pontuais como toxicidade de efluente, síntese de compostos influência ambientais de alérgenos e dores musculo esquelética em ambientes interiores. Todos esses temas refletem a diversas experiências vivenciadas por nossos alunos na elaboração e concepção de suas dissertações de mestrado. Os textos foram submetidos a avaliação de um corpo editorial compostos por professores doutores de diferentes áreas e revisão da linguagem escrita. Desta forma esperamos que as experiências aqui apresentadas contribuam para reflexões no cotidiano das Instituições levando a uma melhor compreensão das questão ambientais ligadas à saúde e ao planejamento de um ambiente mais harmonioso para todos.

Desejamos uma boa leitura

Grata 


\title{
ANÁLISE DE FOCOS DE QUEIMADAS NO MARANHÃO DURANTE EVENTOS DE SECA DE 2010 A 2016.
}

\author{
Denilson da Silva Bezerra ${ }^{1}$; \\ Liene S. Pereira²; \\ Viviane de Gomes Brito; \\ Raoni B. Tomaz ${ }^{2}$ \\ ${ }^{1}$ Professor do Mestrado em Meio Ambiente da Universidade Ceuma \\ 2 Mestrando em Meio Ambiente da Universidade Ceuma
}




\section{RESUMO}

O objetivo do presente capitulo é discorrer sobre a vulnerabilidade do Maranhão a eventos de queimadas entre 2010 a 2016. O procedimento metodológico adotado consistiu em uma revisão bibliográfica e de busca de dados/informações em instituições que atuam direta e/ou indiretamente com a temática. Os impactos da seca no Maranhão são de natureza de dificuldade de acesso à água, perdas na agropecuária, perdas de bens matérias, risco à vida humana e perdas de biodiversidade nos biomas e ecossistemas maranhenses. Um impacto que merece destaque são os focos de queimadas, uma vez que os dados e pesquisas existentes indicam que sua ocorrência é modulada por eventos de secas.

Palavras-chave: Maranhão. Secas. Impactos. Focos de queimadas.

\section{INTRODUÇÃO}

O estado do Maranhão apresenta grande variedade de ecossistemas devido sua a sua localizada entre o nordeste e o norte, ou seja, entre as condições do semiárido brasileiro e ao bioma amazônico, se destacando assim como um verdadeiro conjunto de ambientes transacionais, onde predominam as seguintes formações vegetais: floresta ombrófila densa, savana (cerrado), savana estépica, floresta estacional decídua, floresta estacional e formações com influência marinha e flúvio marinha (Azevedo, 2002).

O Maranhão faz parte do nordeste brasileiro, porém, devido a sua posição geográfica recebe influência tanto do clima úmido da Amazônia quanto do semiárido nordestino, o que levou o Ministerial da Integração Nacional (MI) em 2005 a retirar o Estado do perímetro oficial do Semiárido Brasileiro (SAB).

Contudo, há questionamentos da não inserção do Maranhão como parte integrante do SAB (Lemos, 2007), aliado a isso, a falta de dados e pesquisas específicas voltadas para o tema, e a dificuldade da própria academia em relação a essa temática, faz com que a participação do Maranhão fique comprometida em ações governamentais voltadas ao combate a cenários de seca extrema, a acesso a água de qualidade e temas afins como a questão do combate a eventos de focos de calor. Nos últimos anos os focos de queimadas têm-se evidenciado como um fator agravante que pode maximizar a vulnerabilidade do Maranhão a eventos de secas prolongados como foi observado para o intervalo temporal de 2010 a 2016. 
O conceito de vulnerabilidade adotado na presente pesquisa corresponde ao grau de suscetibilidade ou incapacidade de um sistema lidar com os efeitos adversos da mudança no clima, incluindo a variabilidade climática e os eventos extremos de tempo, conforme proposto pelo Painel Intergovernamental de Mudanças Climáticas - IPCC (IPCC, 2013). Cabe ressaltar ainda que, o conceito de vulnerabilidade apresentado pelo IPCC é voltado para os eventos extremos de tempo, que para o caso da presente pesquisa é direcionado a períodos prolongados de estiagem/seca.

O objetivo do presente artigo é evidenciar a vulnerabilidade do Maranhão a eventos de estiagem, tomando-se como referência o intervalo de tempo compreendido de 2010 a 2016, destacando os impactos socioambientais, as peculiaridades maranhenses para cenários de estiagens extremos e quais as medidas adotadas pelos gestores públicos (a nível municipal, estadual e federal) e pela sociedade civil organizada para garantir a qualidade ambiental e de vida humana. Para cumprimento da finalidade proposta, foi realizada uma minuciosa revisão bibliográfica e de busca de dados/informações em instituições governamentais e não governamentais que atuem direta e/ou indiretamente com a temática abordada

\section{Il.Impactos Ambientais dos Focos de Calor no Período de 2010 A 2016}

De todos os impactos diretos ou indiretos que podem ser induzidos por um período prolongado de secas no Maranhão, os focos de queimadas se constituem como um dos principais tensores ambientais que podem alterar a qualidade de vida humana, bem como biomas e ecossistemas maranhenses.

O Padrão de ocorrência dos focos de queimadas no Maranhão é modulado pela ocorrência ou não da precipitação (Silva Junior et al., 2015), ou seja, os padrões de secas no Maranhão modulam o fenômeno de queimadas nos biomas maranhenses. Tal cenário ocorre devido ao aumento da inflamabilidade da vegetação, como consequência do déficit hídrico decorrente do período de estiagem (Aragão et al., 2009). Como um exemplo de modulação dos focos de queimadas em relação ao padrão de precipitação descrito para o Maranhão, pode-se mencionar o estudo de Silva Junior et al. (2016), que descrevem como a ocorrência de focos de queimadas está correlacionada à 
presença de períodos de secas na região da Baixada Maranhense, para o espaço temporal de 2000 a 2013.

De acordo com o Programa de Monitoramento de Queimadas do Instituto Nacional de Pesquisas Espaciais (INPE), o Maranhão possui uma elevada ocorrência de focos de queimadas, sendo um dos Estados da Amazônia Legal, onde mais ocorre esse fenômeno. Em 2016, por exemplo, o Maranhão foi o terceiro estado com maior número de queimadas em território nacional. Segundo dados do INPE, de janeiro até o mês de dezembro do referido ano, foram registrados pelos satélites cerca de 20.733 focos de queimadas. Todos os biomas maranhenses são afetados pelos focos de queimadas, o que pode induzir perda da diversidade biológica e alterações nos serviços ambientais prestados por estes. A Figura 1 evidencia a distribuição espacial dos focos de queimadas nos biomas maranhenses no intervalo temporal de 11/11/2015 a 11/11/2016.

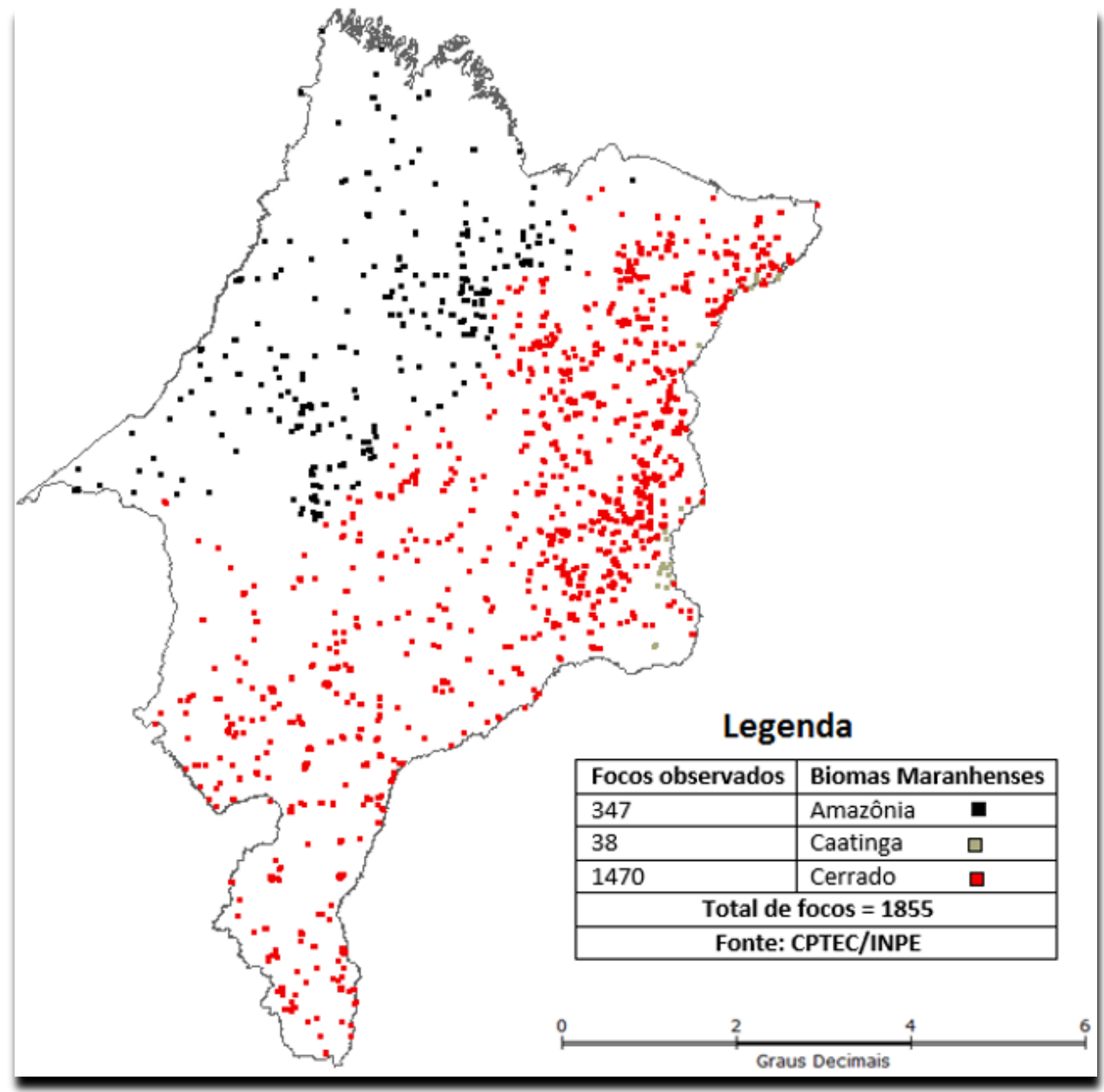


Figura 1. Focos de queimadas detectados nos biomas maranhenses de 11/11/2015 a 11/11/2016. Fonte: Adaptado do CPETC/INPE.

Para o espaço temporal considerado (2010-2016) na presente pesquisa, é nítido a modulação dos focos de queimadas em relação aos meses onde é predominante o período de secas (de julho a aproximadamente dezembro), pois sua intensidade de ocorrência é marcante nos meses com pouca precipitação, com o clímax entre os meses de julho a outubro, conforme pode ser observado na Figura 2.

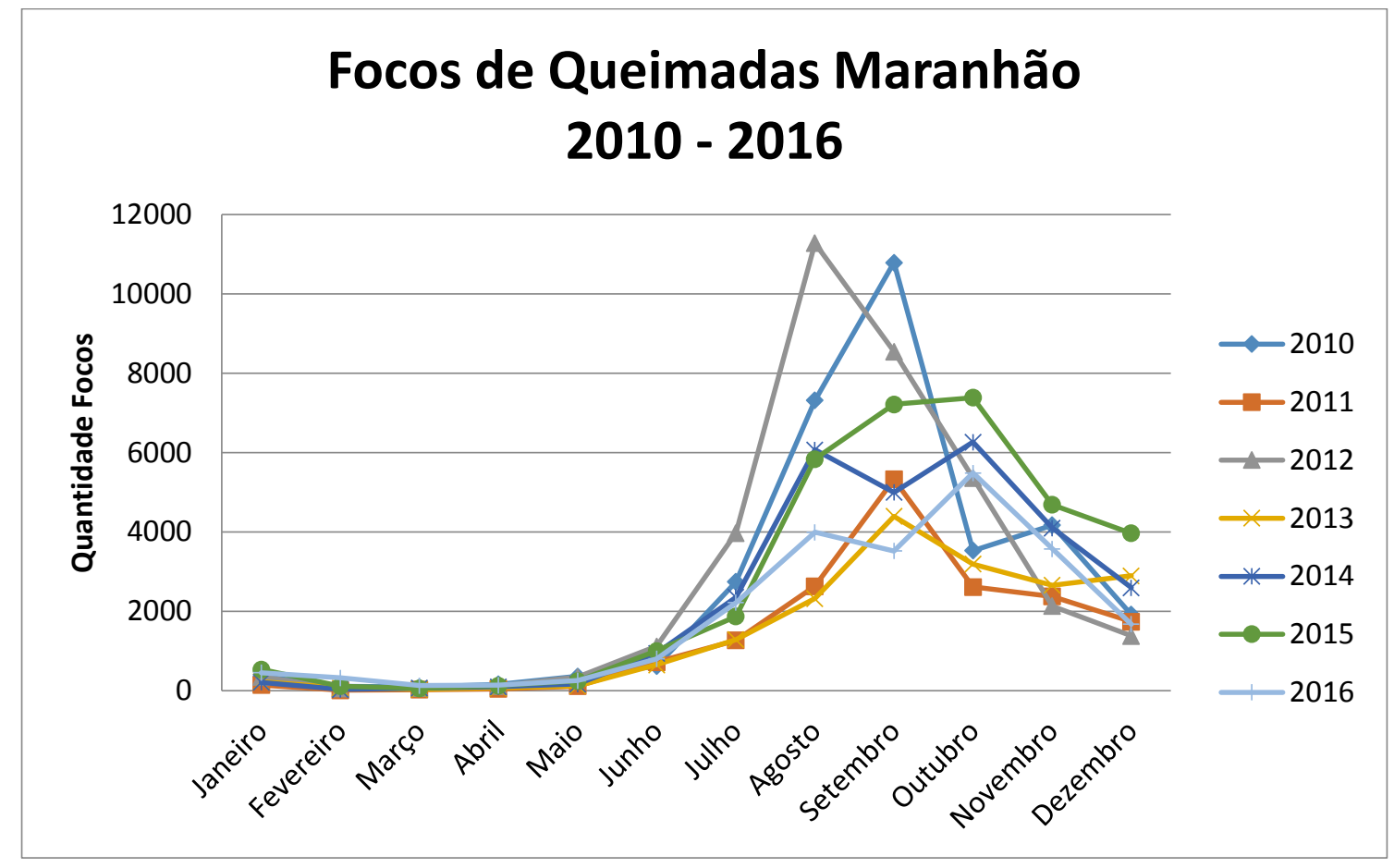

Figura 2. Focos de queimadas registrados mensalmente no Maranhão, no período de 2010 a 2016. Fonte: Autores.

Ainda em relação ao período temporal analisado, cabe ressaltar que houveram notificações de 185.263 focos de queimadas registrados por satélites do INPE no Estado do Maranhão, sendo o ano de maior ocorrência em 2012 com 34.713 focos (18,74\%), seguido de $2015 \mathrm{com} 33.029$ focos (17,83\%), $2010 \mathrm{com}$ 32.167 focos (17,36\%), 2014 com 27.882 focos (15,05\%), 2016 com 22.558 focos (12,18\%), 2013 com 17.909 (9,67\%) e por fim, o ano de 2011 com 17.005 focos registrados $(9,18 \%)$.

Constata-se com os números de focos registrados e com valores percentuais observados para o mencionado intervalo temporal, que as 
queimadas constituem-se como um expressivo impacto ambiental no Maranhão intensificado por eventos de seca e/ou estiagem, e que há uma constância temporal nesse fenômeno.

Il.1. Impactos Socioeconômicos dos Focos de Calor no Período De 2010 A 2016

Os focos de queimadas correspondem ao principal impacto ambiental de eventos de secas no Maranhão, uma vez que, há indícios que cenários de pouca precipitação (seca) modulam a o padrão de ocorrência de secas (Caldas; Silva; Silva Junior, 2014), mesclado também às formas de uso e ocupação de origem antrópica, como é verificado no sistema de cultivo de agricultores familiares, denominado "Roça no toco ou corte/queima.

Os principais impactos provocados por eventos de queimadas são: risco à vida humana, poluição do ar com potenciais implicações negativas à saúde, perda de áreas agricultáveis, perda de biodiversidade, alterações em ecossistemas terrestre e lacustres, alterações nos biomas, perda de bens materiais e na agricultura industrializada e na familiar.

A população rural é a mais vulnerável ao fenômeno das queimadas, pois devidos às suas características geográficas e ambientais, as incidências de focos são mais comuns nestas áreas, que normalmente correspondem ao percentual da população com os piores dados de qualidade de vida e quem tem mais dificuldade para obter suporte por meio de políticas governamentais.

Os municípios maranhenses de maior recorrência histórica a eventos de secas no período, são: Anapurus, Brejo, Buriti, Chapadinha, Duque Bacelar, Coroatá, Mata Roma, São Bernardo, Santa Quitéria do Maranhão, Coelho Neto, Timbiras, Codó, Caxias, Timon, Matões e Colinas. Contudo, cabe ressaltar não apenas os municípios mencionados como vulneráveis, pois nas últimas décadas vários outros municípios decretaram estado de emergência como resposta a eventos de secas, como pode ser observado na Figura 6 que evidencia a distribuição do número de municípios que historicamente 1 já decretaram estado de emergência à eventos de secas.

Durante o último período de estiagem extrema observado entre 2010 a 2016, um total de 1.176 .680 pessoas foram direta ou indiretamente afetadas em vários municípios, o que evidencia a necessidade de haver eficiência nos

\footnotetext{
${ }^{1}$ Entende-se como série histórica para a presente pesquisa, o período de 1991 a 2010, intervalo temporal onde estão disponíveis os dados de fontes oficiais para o Maranhão (IMESC, 2016).
} 
serviços públicos de atendimento à população maranhense, assim como, também, demonstra que há uma grande demanda por pesquisa em várias áreas do conhecimento humano, para minimizar e/ou mitigar os efeitos das secas no Maranhão.

Somente no 2016, o CGCB/MA estima que foram perdidas 46 moradias em decorrência das queimadas no território maranhense, outras 110 sofreram danos parciais. Os prejuízos financeiros, ainda de acordo com o CGCB/MA, somam valores da ordem de: $R \$ 1.420 .385,00$ no comércio, $R \$ 4.093 .729,56$ na agricultura e $R \$ 10.202 .230,60$ na pecuária.

Com relação aos valores de perdas monetárias e de números de pessoas potencialmente atingidas, cabe ressaltar que inexiste no Maranhão uma política pública de acompanhamento e mensuração dos impactos de eventos de secas prolongados. Dessa forma, os valores mencionados podem ser subestimados. Mesmo assim, os valores apresentados na presente pesquisa servem como um indicador da gravidade dos impactos socioambientais induzidos por eventos de secas.

Outro importante indicador refere-se ao número de decretações de situação de emergência em decorrência de eventos de secas severas no Maranhão, que segundo CGCB/MA, totalizaram 207 decretos para o período de 2010 a 2016; sendo 77 decretações municipais e 130 decretações estaduais.

\section{II.3.Ações Governamentais e Não Governamentais Para Adaptação dos} Impactos Da Seca no Período de 2010 A 2016

Para a presente pesquisa, entende-se que eventos de secas podem ser influenciados por mudanças climáticas induzidas por atividades antrópicas, assim, as ações governamentais e não governamentais para combate à seca no Maranhão entre 2010 a 2016 são analisadas mediantes ao conceito de adaptação da Política Nacional Sobre Mudança do Clima (PNSM). Ou seja, a adaptação pode ser entendida como um conjunto de respostas aos potenciais impactos atuais da mudança do clima, tendo por meta reduzir eventuais danos e ainda promover oportunidades (BRASIL, 2008).

O PNSM indica que a capacidade de adaptação de um sistema depende basicamente de duas variáveis: a vulnerabilidade e a resiliência. A vulnerabilidade, que é reflexo do grau de suscetibilidade do sistema para lidar 
com os efeitos adversos da mudança do clima. E resiliência é a habilidade que sistema em absorver os impactos preservando a mesma estrutura básica e os mesmos meios de funcionamento.

Os programas governamentais maranhenses de apoio às secas auxiliam a resiliência da população ao promoverem mais condições à população para resistirem a eventos de secas prolongados. Os programas maranhenses podem ser subdivididos em três categorias, estes a saber são: de acesso a água, planejamento e de intervenção a obras de engenharia. As ações de acesso a água se caracterizam por ações do governo estadual, federal e/ou da sociedade civil organizada com intuito a aumentar a oferta de água (em quantidade e qualidade) mesmo em períodos prolongados de secas. As ações de planejamento caracterizam-se por apresentar elaboração de planos, projetos e de dados direcionados de forma direta ou indireta à temática da seca. E ações de intervenção de obras de engenharia, esta categoria refere-se a ações governamentais que necessitam de intervenções de engenharia para sua implementação.

A Tabela 1 sintetiza os principais programas governamentais e não governamentais de combate a eventos de secas em território maranhense no período de 2010 a 2016.

Tabela 1. Ações governamentais e não governamentais para adaptação no Maranhão a eventos de secas para o período de 2010 a 2016.

\begin{tabular}{|c|c|c|c|c|c|}
\hline Projeto /ação & Responsável & Financiamento & Início & Categoria & Meta \\
\hline $\begin{array}{l}\text { Programa } 1 \\
\text { Milhão de } \\
\text { Cisternas }\end{array}$ & $\begin{array}{l}\text { Articulação do } \\
\text { Semiárido } \\
\text { (ASA/MA) }\end{array}$ & Sociedade Civil & 2010 & $\begin{array}{c}\text { Acesso a } \\
\text { Água }\end{array}$ & $\begin{array}{l}\text { Acesso a água } \\
\text { por meio da } \\
\text { construção de } \\
\text { cisternas. }\end{array}$ \\
\hline $\begin{array}{c}\text { Plano de Ação } \\
\text { para Prevenção } \\
\text { e Controle do } \\
\text { Desmatamento } \\
\text { e das } \\
\text { Queimadas no } \\
\text { Estado do } \\
\text { Maranhão. }\end{array}$ & $\begin{array}{c}\text { Secretaria de } \\
\text { Estado do Meio } \\
\text { Ambiente e } \\
\text { Recursos Naturais } \\
\text { Renováveis } \\
\text { (SEMA). Apoio do } \\
\text { Ministério do Meio } \\
\text { Ambiente (MMA). }\end{array}$ & $\begin{array}{c}\text { Banco Mundial e } \\
\text { Governo da } \\
\text { Noruega. }\end{array}$ & 2011 & Planejamento & $\begin{array}{c}\text { Planejamento } \\
\text { de ações ao } \\
\text { combate ao } \\
\text { desmatamento } \\
\text { e a ocorrência } \\
\text { de queimadas } \\
\text { no Maranhão. }\end{array}$ \\
\hline $\begin{array}{c}\text { Programa de } \\
\text { Ação Estadual } \\
\text { de Prevenção e } \\
\text { Combate à }\end{array}$ & $\begin{array}{c}\text { Instituto } \\
\text { Maranhense de } \\
\text { Meio Ambiente e } \\
\text { Recursos Hídricos }\end{array}$ & $\begin{array}{l}\text { Ministério do } \\
\text { Meio Ambiente } \\
\text { (MMA). }\end{array}$ & 2012 & Planejamento & $\begin{array}{l}\text { Planejamento } \\
\text { de ações ao } \\
\text { combate à } \\
\text { desertificação e }\end{array}$ \\
\hline
\end{tabular}




\begin{tabular}{|c|c|c|c|c|c|}
\hline $\begin{array}{l}\text { Desertificação e } \\
\text { Mitigação dos } \\
\text { Efeitos da Seca } \\
\text { do Estado do } \\
\text { Maranhão - } \\
\text { PAE (MA) }\end{array}$ & $\begin{array}{c}\text { (IMARH). } \\
\text { Secretaria de } \\
\text { Estado do Meio } \\
\text { Ambiente e } \\
\text { Recursos Naturais } \\
\text { Renováveis } \\
\text { (SEMA). }\end{array}$ & & & & $\begin{array}{c}\text { aos efeitos da } \\
\text { seca no } \\
\text { Maranhão. }\end{array}$ \\
\hline $\begin{array}{c}\text { Programa Água } \\
\text { Doce no } \\
\text { Maranhão } \\
\text { (PAD) }\end{array}$ & $\begin{array}{l}\text { Secretária da } \\
\text { Agricultura } \\
\text { Familiar (SAF). }\end{array}$ & $\begin{array}{l}\text { Ministério do } \\
\text { Meio Ambiente } \\
\text { (MMA). }\end{array}$ & 2016 & $\begin{array}{c}\text { Acesso a } \\
\text { água }\end{array}$ & $\begin{array}{l}\text { Dessalinização } \\
\text { de poços } \\
\text { d'água do } \\
\text { ambiente rural. }\end{array}$ \\
\hline $\begin{array}{c}\text { Programa } \\
\text { Cisternas } \\
\text { (Segunda Água) }\end{array}$ & $\begin{array}{c}\text { Secretária da } \\
\text { Agricultura } \\
\text { Familiar (SAF). }\end{array}$ & $\begin{array}{l}\text { Ministério do } \\
\text { Meio Ambiente } \\
\text { (MMA). }\end{array}$ & 2016 & $\begin{array}{c}\text { Acesso a } \\
\text { água }\end{array}$ & $\begin{array}{l}\text { Acesso a água } \\
\text { por meio da } \\
\text { construção de } \\
\text { cisternas no } \\
\text { meio rural. }\end{array}$ \\
\hline $\begin{array}{l}\text { Barragens de } \\
\text { Contenção na } \\
\text { Baixada } \\
\text { Maranhense }\end{array}$ & $\begin{array}{c}\text { Responsável: } \\
\text { Secretária de } \\
\text { Estado de } \\
\text { Desenvolvimento } \\
\text { Social (SEDES) }\end{array}$ & $\begin{array}{l}\text { Governo do } \\
\text { Estado do } \\
\text { Maranhão. }\end{array}$ & 2016 & $\begin{array}{l}\text { Obras de } \\
\text { engenharia. }\end{array}$ & $\begin{array}{c}\text { Orientar a } \\
\text { construção de } \\
\text { barragens para } \\
\text { retenção da } \\
\text { água no } \\
\text { período } \\
\text { chuvoso na } \\
\text { Baixada } \\
\text { Maranhense. }\end{array}$ \\
\hline $\begin{array}{c}\text { Projeto de } \\
\text { Construção de } \\
\text { Canais de } \\
\text { Acumulação de } \\
\text { Água }\end{array}$ & $\begin{array}{c}\text { Responsável: } \\
\text { Secretária de } \\
\text { Estado de } \\
\text { Desenvolvimento } \\
\text { Social (SEDES) }\end{array}$ & $\begin{array}{l}\text { Governo do } \\
\text { Estado do } \\
\text { Maranhão. }\end{array}$ & 2016 & $\begin{array}{l}\text { Obras de } \\
\text { engenharia. }\end{array}$ & $\begin{array}{c}\text { Orientar a } \\
\text { construção de } \\
\text { canais para } \\
\text { retenção da } \\
\text { água no } \\
\text { período } \\
\text { chuvoso na } \\
\text { Baixada } \\
\text { Maranhense. }\end{array}$ \\
\hline $\begin{array}{l}\text { Zoneamento } \\
\text { Agropecuário do } \\
\text { Maranhão } \\
\text { (ZAMA) }\end{array}$ & $\begin{array}{l}\text { Secretária da } \\
\text { Agricultura, } \\
\text { Pecuária e } \\
\text { Abastecimento } \\
\text { (SAGRIMA). }\end{array}$ & $\begin{array}{l}\text { Governo do } \\
\text { Estado do } \\
\text { Maranhão. }\end{array}$ & 2016 & Planejamento & $\begin{array}{c}\text { Minimizar } \\
\text { os riscos } \\
\text { relacionados } \\
\text { aos fenômenos } \\
\text { climáticos. }\end{array}$ \\
\hline
\end{tabular}

Fonte: Os autores

\section{CONCLUSÕES}

Se comparado com os demais estados do nordeste, o Maranhão apresenta expressivo potencial hídrico, contudo, os dados e informações referente ao período de seca no Maranhão apresentados na pesquisa indicam 
que o Maranhão foi um Estado vulnerável a eventos de secas, para o intervalo de tempo considerado (2010 - 2016). Tal cenário se deve a sua localização transicional entre a Amazônia Legal e o Semiárido Brasileiro, o que proporciona um balanço hídrico bastante complexo, caracterizado por seis meses de período chuvoso e seis meses de secas.

Os principais impactos socioambientais podem ser sumarizados em implicações negativas de acesso a água, perdas nas atividades agropecuárias, perdas de bens matérias, risco à vida humana e potenciais prejuízos a biodiversidade nos biomas e ecossistemas maranhenses. Um impacto que merece destaque no território maranhense são os focos de queimadas, uma vez que os dados e pesquisas existentes indicam que sua ocorrência é modulada por eventos de secas.

E por fim, destaca-se que o Maranhão não apresenta um padrão climáticosazonal igual aos demais Estados do Nordeste brasileiros a eventos de secas, porém nem por isso, pode ser considerado menos vulnerável a ocorrência desse fenômeno.

\section{LEITURA COMPLEMENTAR}

Para leitura suplementar indica-se as seguintes referências que abordam a temática de queimadas, desertificação e secas/estiagens para o Maranhão:

Maranhão. Secretaria de Estado do Meio Ambiente e Recursos Naturais (2012). Programa de Ação Estadual de Combate à Desertificação e Mitigação dos Efeitos da Seca no Estado do Maranhão / Secretaria de Estado do Meio Ambiente e Recursos Naturais. - São Luís: EDUEMA, 298 p. Disponível em < http://www.iicadesertification.org.br/attachments/category/18/PAE MA.pdf>.

PIROMAL, R. A. S. et al. Utilização de dados MODIS para a detecção de queimadas na Amazônia. Acta Amazonica, v. 38, n. 1, p. 77-84, 2008. 


\section{REFERÊNCIAS}

ARAGÃO, L. E. O. C. et al. Interactions between rainfall, deforestation and fires during recent years in the Brazilian Amazonia. Philosophical transactions of the Royal Society of London. Series B, Biological Sciences, v. 363, n. 1498, p. 1779-85, 27 maio 2009.

AZEVEDO, A. C. G. Ecossistemas maranhenses série ecológica: 1. São Luís, MA: UEMA Editora, 2002.

BRASIL - Plano Nacional Sobre Mudança do Clima (PNMC). Comitê Interministerial Sobre Mudança do Clima. Decreto no 6.263, de 21 de novembro de 2007. Brasília, dezembro de 2008, 132.

CALDAS, J. M.; Silva, F. B.; Silva Junior, C. H. L. Análise de focos de queimadas no Parque Estadual do Mirador utilizando um Sistema de Informação Geográfica - SIG, Estado do Maranhão, Brasil. In: PROCEEDINGS OF SAFETY, HEALTH AND ENVIRONMENT WORLD CONGRESS, 14., 2014, Cubatão. Anais... Cubatão: COPEC, $2014 . \quad$ Disponível em: $<$ http://proceedings.copec.org.br/index.php/shewc/article/view/2378>. Acesso em: 5 out. 2014.

EMBRAPA. Relatório do diagnóstico do macrozoneamento ecológicoeconômico do Estado do Maranhão / Mateus Batistella, Édson Luis Bolfe, Luiz Eduardo Vicente, Daniel de Castro Victoria, Luciana Spinelli Araujo (Org.). Campinas, SP: Embrapa, 2013. 325 p.

IPCC. Working group I Contribution to the IPCC fifth assessment Report (AR5), climate change 2013: the physical science basis. Cambridge Univ. Press, 2013. $2216 p$.

LEMOS, J. J. S. Inserção do Maranhão no Semiárido do Brasil. 2007, 21p. Disponível em: <http://www.lemos.pro.br/admin/artcientifico/124111604949f9ed91495d2.pdf.>. Acesso: 22/04/2017.

MARANHÃO - Atlas do Maranhão/Gerência de planejamento e desenvolvimento econômico, Laboratório de Geoprocessamento (LABGEO/UEMA). São Luís: GEPLAN. 2002, $36 \mathrm{p}$.

SILVA JUNIOR, C. H. L. et al. A zona de transição entre a Amazônia e o Cerrado no estado do Maranhão. Parte II: Caracterização preliminar dos dados de área queimada (Produto MODIS MCD45A1). In: SIMPÓSIO BRASILEIRO DE SENSORIAMENTOSIMPÓSIO BRASILEIRO DE SENSORIAMENTO, 17, 2015, João Pessoa. Anais... João Pessoa: INPE, 2015. 


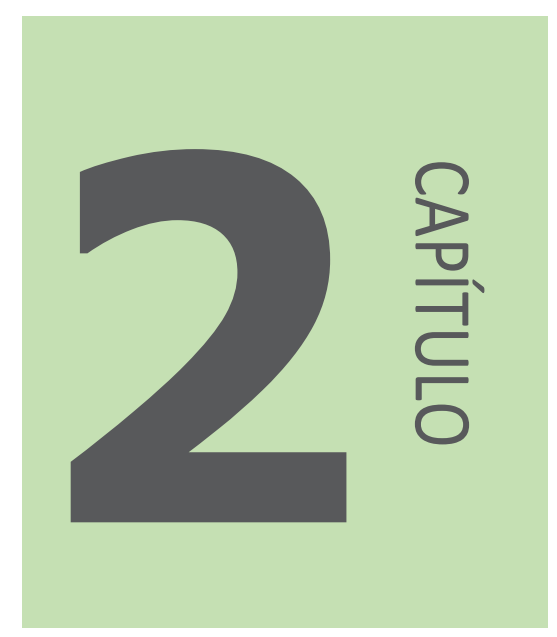

\title{
ISOLAMENTO DE MICRORGANISMOS DE INTERESSE BIOTECNOLÓGICO ORIUNDOS DE ÁREAS CONTAMINADAS COM AGROQUÍMICO
}

\author{
Mariana Santos Costa', \\ Thalison Rômulo Rocha Araújo', \\ Ábia de Jesus Martins ${ }^{1}$, \\ Queren Hapuque Sousa da Silva ${ }^{1}$, \\ Celso Henrique Costa², \\ Rita de Cássia Mendonça de Miranda ${ }^{3}$ \\ ${ }^{1}$ Graduação em Biomedicina - Universidade Ceuma \\ ${ }^{2}$ Mestrando em Meio Ambiente - Universidade Ceuma \\ ${ }^{3}$ Docente Doutora do Mestrado em Meio Ambiente da Universidade Ceuma
}




\section{RESUMO}

Introdução: Sabe-se que o solo é um dos principais locais que são habitados por uma grande variedade de microrganismos incluindo bactérias, fungos, algas, protozoários e vírus. O uso dos agroquímicos hoje tem causado dúvidas sobre a baixa ou inexistente patogenicidade nos microorganismos de solo, visto que, esses químicos, quando usados incorretamente, podem acarretar alterações a esses microorganismos, os tornando mais resistentes gerando como consequência, problemas principalmente aos trabalhadores que estão sempre em contato, e aos consumidores finais do produto o qual esta sendo cultivado. Objetivo: Isolar e identificar os microorganismos encontrados no solo acometido pelo agroquímico para tentar identificar presença de patógenos. Materiais e métodos: foram usados métodos simples, preconizados na metodologia de Clark (1965), isolando microrganismos provenientes de diluição seriada do solo. O solo utilizado na pesquisa foi de 10 amostras separadas de forma equidistantes, com distancia de três metros uma de cada, de um único canteiro de uma horta situada no bairro J. Lima, em São José de Ribamar. Foram feitos o isolamento e identificação durante períodos seco e chuvoso, e após o isolamento, a identificação foi realizada através do microcultivo, no caso dos fungos, e a partir da coloração de Gram, no caso das bactérias. Resultados: Observando as colônias formadas e após identificar os microrganismos, notou-se a presença de fungos patógenos como principalmente a espécie Coccidioide sp., e bactérias cocos e bastonetes gram positivo e negativo, que podem também gerar sensibilidade ao usuário do alimento e principalmente ao trabalhador, partindo de que geralmente os químicos não são usados corretamente e também não há o uso dos equipamentos de proteção. Conclusão: De acordo com os resultados observados, analisando a presença de microrganismos patogênicos no solo avaliado, percebemos que os microrganismos de solo podem, também gerar malefícios a sociedade, quando observados em solo com o uso indevido dos agroquímicos.

\section{Introdução}

A ecologia microbiana do solo trata das relações dos microrganismos do solo com os fatores abióticos (ambientais) e bióticos (interação com outros organismos) (Leite Luiz et. al, 2007). Ele configura um corpo organizado que contém provavelmente maior número de indivíduos e maior diversidade que qualquer outro habitat ou ecossistema. Os organismos que compõe a pedobiota desempenham funções essenciais para o funcionamento do ecossistema, pois tem como função primária, governar as reações de ciclagem e fluxos dos vários nutrientes essenciais, influenciando assim diretamente a fertilidade do solo, além de exercer efeitos na formação da estrutura e manutenção dos agregados e sua sanidade como meio de crescimento vegetal e sustentáculo da produção agrícola. (Martins, Marco Antonio, 2013) 
Do ponto de vista microbiológico, o solo é ambiente estressante, fortemente limitado por nutrientes, mas capaz de sustentar uma população microbiana extremamente diversa. (Siqueira, José 1994 apud. Domergues et. Al 1978). Segundo Souto et al. (2008), entre os componentes da biota do solo, as bactérias e os fungos detém altos valores de biomassa e metabolismo respiratório, além de exercerem alta contribuição no processo de decomposição da matéria orgânica.

O uso de agroquímicos tem sido um fator importante para o trabalho agrícola no Brasil, devido suas funções acerca da proteção de determinadas vegetações. Porém, é de extrema importância o impacto causado por eles sobre o meio ambiente e a saúde humana.

A principal função desses compostos é inibir o crescimento de patógenos frequentes na agricultura já que de um modo geral possuem estruturas químicas e moleculares semelhantes a classes de antimicrobianos usados na clínica. Estes compostos possuem similaridade estrutural com azólicos clínicos e alguns passaram a ser proibido no Brasil pela ANVISA, motivado principalmente pela elevada toxicidade do produto (Chowdhary et al., 2013; Faria \& Ramos et al., 2014).

A contaminação do solo por agroquimicos afeta direta e/ou indiretamente os microrganismos que vivem nesse meio, os mesmos são essenciais para armazenamento de água, decomposição de resíduos orgânicos, reciclagem de nutrientes, sequestro e desintoxicação de substâncias tóxicas (Lima, 2008).

Em vista disso, faz-se necessário o estudo da microbiota do solo em locais contaminados, podendo ser uma maneira de provar que o contaminante pode causar sérios problemas a população. Nesse sentido, o presente trabalho visa quantificar e analisar fenotipicamente microorga-nismos isolados de solo contaminado por agroquímico utilizado na agricultura de hortaliça.

\section{Material e Método}

Para iniciar o trabalho, foram realizadas duas coletas obedecendo um período de sazonalidade seco (janeiro) e chuvoso (abril) de solo impactado com agroquímico da classe dos organofosforados. Esta etapa foi realizada em uma 
propriedade de agricultura que cultiva hortaliças localizada no município de são José de Ribamar, no bairro J. Lima.

Foram coletadas 10 amostras de solo separadas de forma equidistantes de um único canteiro da mesma horta. A distância entre as amostras foi de 3 metros uma da outra.

Após a coleta, as amostras foram armazenadas em sacos hermeticamente vedados e acondicionados sob refrigeração para posterior isolamento dos microrganismos.

Para o isolamento dos microrganismos foi elaborada uma amostra composta do solo e utilizada a técnica de diluição seriada de acordo com a metodologia preconizada por Clark (1965). Para isso diluiu-se $10 \mathrm{~g}$ da amostra composta do solo em $90 \mathrm{~mL}$ de solução salina. A partir desta solução, foram realizadas as diluições posteriores $\left(10^{-1}\right.$ até $\left.10^{-4}\right)$ em tubos de ensaio contendo $0,5 \mathrm{~mL}$ das amostras e $4,5 \mathrm{~mL}$ de solução salina. As diluições $10^{-2}, 10^{-3} \mathrm{e} 10^{-4}$ foram inoculadas através da técnica de spread plate nos meios de cultivo Muller Hinton Ágar e Sabouraud Dextrose Agar. Após inoculadas, as amostras foram incubadas a $30^{\circ} \mathrm{C}$ até o aparecimento das colônias.

Após o crescimento das colônias nos meios de cultivo, essas foram contadas e posteriormente transferidas separadamente para placas de Petri contendo o mesmo meio de isolamento. Com o objetivo de se obter culturas puras foi utilizada a técnica repicagem por esgotamento. As placas foram incubadas a $30^{\circ} \mathrm{C}$ por 72 horas.

Seguindo o trabalho, depois da obtenção das colônias isoladas e purificadas, as mesmas foram transferidas para tubos de ensaio contendo 0 mesmo meio do isolamento e deu-se início a identificação. Para as bactérias foi realizada a técnica de coloração de Gram onde foi possível dividir em Gram positiva e Gram negativa de acordo com a coloração tintorial da parede celular. Além disso por esta mesma técnica é possível observar morfologia e arranjo bacteriano. Para identificação dos fungos filamentosos se utilizou a técnica de microcultivo, as culturas crescem em forma de tapete na placa de Petri com formação de micélio aéreo para observação microscópica da conformação dos esporos dos fungos. 


\section{RESULTADOS}

Após o período de incubação das placas de Petri, contendo meio de cultura usados no isolamento pode-se observar o aparecimento das colônias.

Após a contagem, constatou-se que a quantidade de microrganismos no período chuvoso é maior que no período seco, como se pode visualizar na Figura 1 e 2, todavia quando se faz a observação macro e microscópica se observa uma diversidade microbiana maior em período seco.

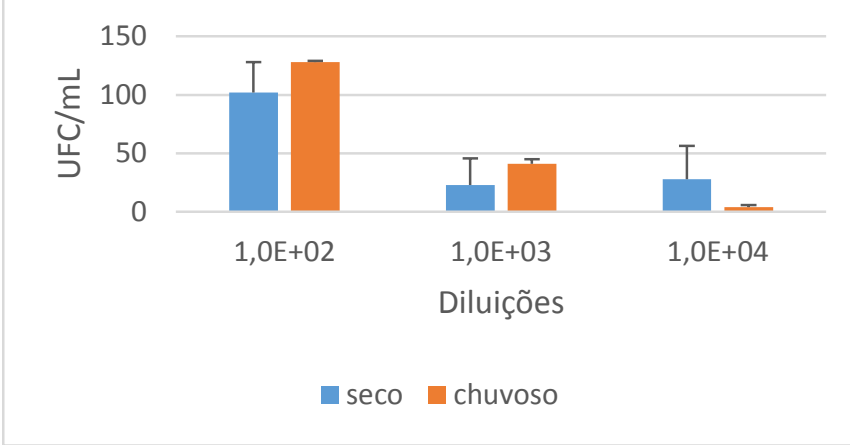

Figura 1 - isolamento de microrganismos no período seco e chuvoso no meio de cultura Muller Hinton Ágar.

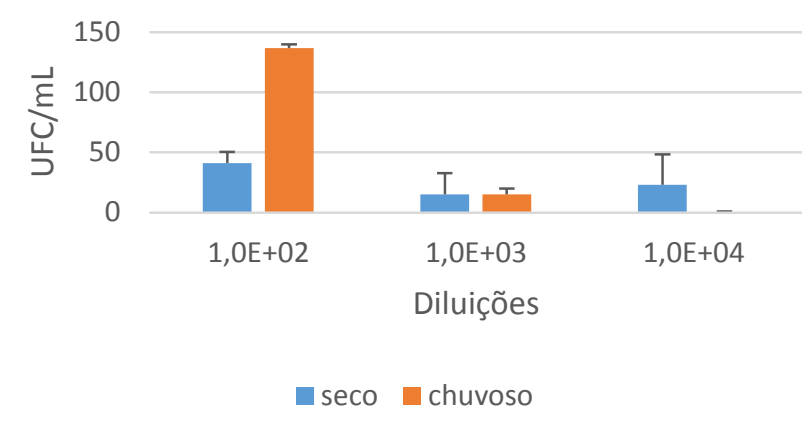

Figura 2 - isolamento de microrganismos no período seco e chuvoso no meio de cultura Sabouraud Dextrose Ágar.

Uma outra observação interessante é a prevalência em ambos os períodos do grupo dos fungos, demonstrando que estes estão em maior número no solo contaminado com agroquímico. Logo após a observação macroscópica, observou-se três grupos distintos de colônias. No meio de cultivo Muller Hinton Ágar as colônias se mostraram mais uniformes em relação ao tamanho, os bordos liso ou em forma de ondas, sugerindo colônias formadas por bactérias do gênero Bacillus. No meio de cultivo Sabouraud Dextrose Ágar observou-se colônias de aspecto algodonoso, sugerindo a formação de micélio aéreo de fungos filamentosos e colônias leitosas opacas e com bordas lisas bem delimitadas características de leveduras. Neste meio também se pode observar a formação de halo de antibiose como pode ser visualizado na Figura 3. 


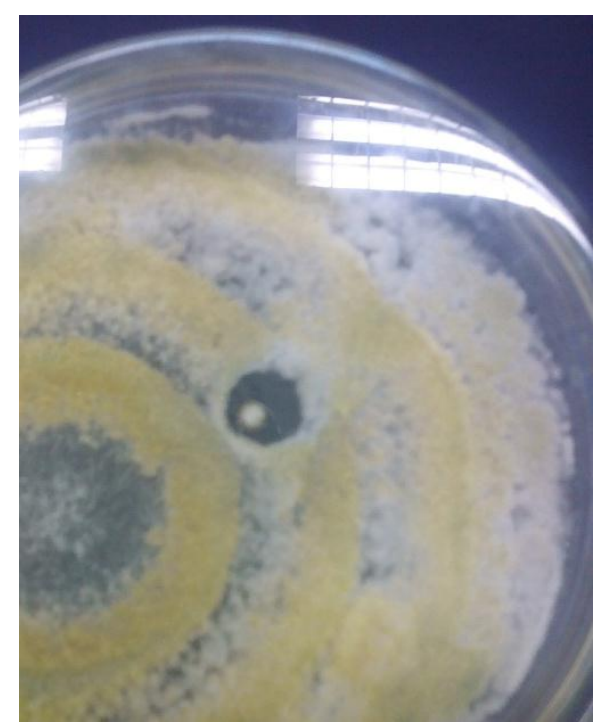

Figura 3 - aspecto macromorfológico das colônias no meio de cultivo Sabouraud Dextrose Ágar.

Posteriormente a contagem e purificação das colônias deu-se início a identificação dos microrganismos. Foi realizado o teste de coloração de Gram para as bactérias e o microcultivo em lâmina para os fungos e o que se observou foi que dos microrganismos isolados $29 \%$ eram Bastonetes $\mathrm{G}^{+}, 13 \%$ Bastonetes $\mathrm{G}^{-}, 29 \%$ Cocos $\mathrm{G}^{+}, 16 \%$ de Fungos Filamentosos e $13 \%$ de Leveduras como pode ser visualizado na Figura 4

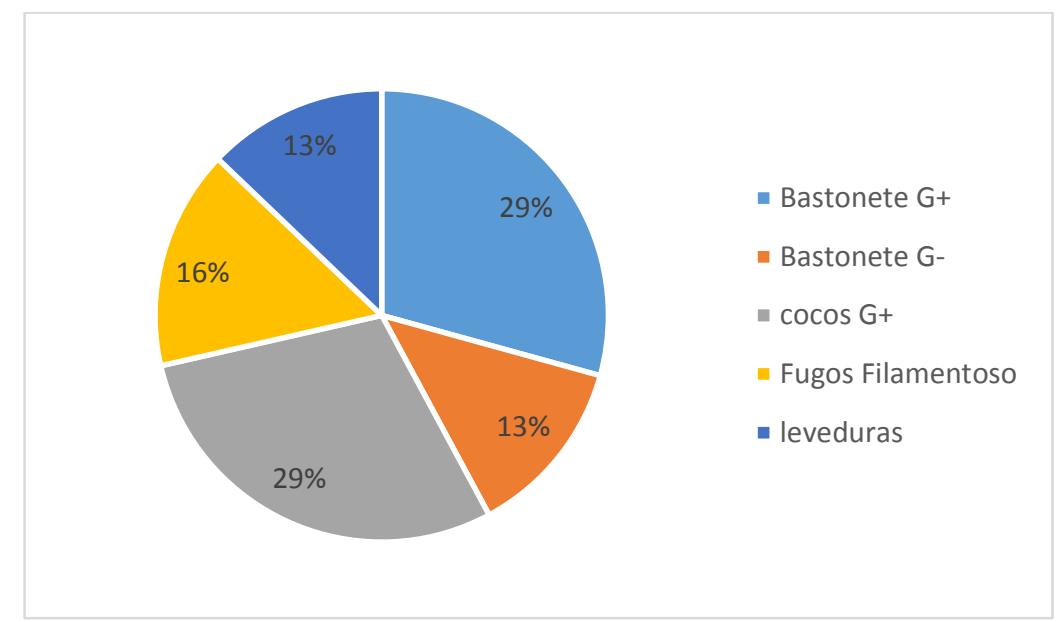

Figura 4 - percentual de microrganismos isolados

Após a coloração tintorial da parede celular (coloração de Gram) pode-se observar a duas formas bacterianas distintas, cocos e bastonetes de ambas as colorações, positiva e negativa. Além disso, foi possível observar alguns arranjos bacteriano como cacho, duas células juntas e uma fileira de células arranjadas. 
Com exceção do grupo das leveduras, pode-se observar diversidade entre os microrganismos, tanto nos aspectos macroscópicos quanto nos microscópicos. A prevalência de bactérias $\mathrm{G}^{+}$pode ser explicada pela habilidade desse grupo bacteriano de resistir a ambientes inóspitos, e também por abrigar o grupo dos Actinomicetales, que são bactérias Gram Positivas filamentososas, diferenciadas das demais Eubactérias. Dentre os fungos filamentosos foram identificados quatro gêneros diferente: três Penicillium spp, 01 Aspergillus sp., 01 Trichoderma sp e um Coccidioide sp., fungo patogênico, comum em solo causador de meningite.

Nas observações micromorfológica dos fungos pode-se observar a conformação dos esporos nas extremidades das hifas, além disso pode-se observar se tratavam de hifas hialinas ou septadas corroborando com a identificação dos fungos. Nas figuras $5 \mathrm{~A}, 5 \mathrm{~B}$ e $5 \mathrm{C}$ se pode visualizar a micromorfologia dos fungos Aspergillus, sp. Penicillium $\mathrm{sp}$ e Coccidioide $\mathrm{sp}$. respectivamentes. As características macromorfológicas avaliadas consistiram no tamanho da colônia, características dos bordos, textura, relevo e pigmentação. Já as análises micromorfológicas foram realizadas pela técnica de microcultivo em ágar-batata, visando identificar as estruturas vegetativas e especialmente as estruturas reprodutivas específicas dos gêneros de fungos filamentosos como pode ser visualizada na figura 5.
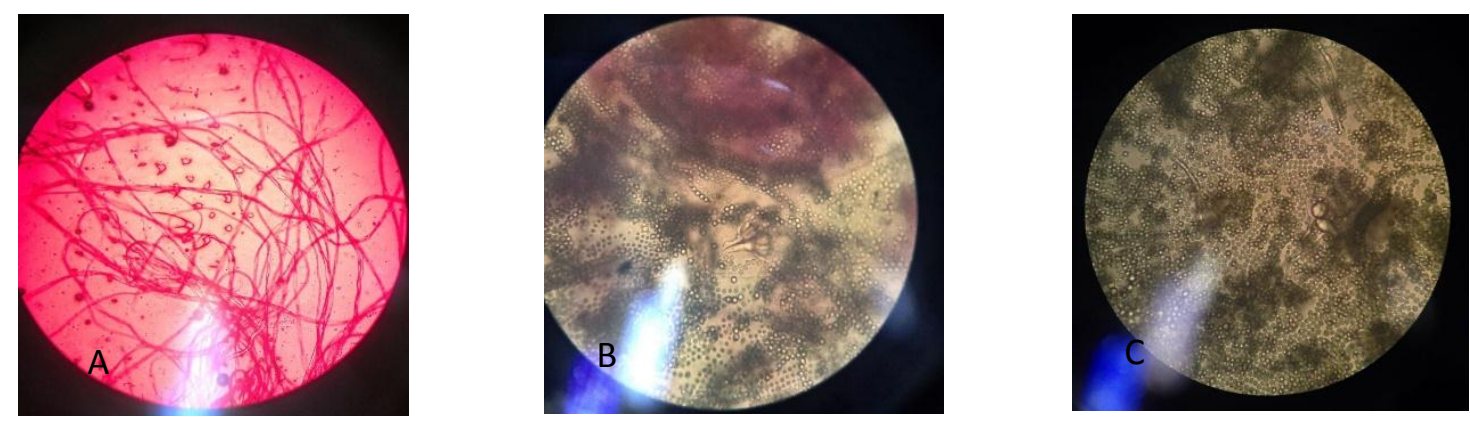

Figura 5 - características micromorfológicas dos fungos filamentosos isolados de solo.

Com os resultados obtidos pode-se observar uma quantidade microbiana elevada dos três grupos isolados. A avaliação das densidades populacionais na comunidade microbiana nos solos inclui a técnica de cultura em placa, exame 
microscópico direto e técnica de enriquecimento (PELCZAR; CHAN; KRIEG, 1997). Na comunidade bacteriana, também existe variabilidade entre as populações de bactérias em geral e de actinomicetos em relação à utilização dos nutrientes manifestos no meio de cultura.

Corroborando com este trabalho pode ser observado no trabalho de SANTOS \& BATISTA (2015). Os autores, isolando microrganismos de solo contaminado com esgoto doméstico nos períodos secos e chuvosos encontraram um quantitativo de $\mathrm{FC} / \mathrm{mL}$ semelhante ao encontrado neste trabalho.

\section{CONCLUSÕES}

Tendo em vista que a estimativa da biomassa microbiana pode fornecer dados úteis sobre modificações nas propriedades biológicas dos solos, decorrentes dos tipos de manejo aplicados e de diferentes culturas (Alvarez, et al. (1995); Franzluebbers, Zuberer, Hons (1995), Jordan et al. (1995), de acordo com os resultados obtidos pode-se observar que mesmo com o solo contaminado com agroquímico, ainda é possível verificar uma ampla quantidade e diversidade microbiana, sendo este fato, preocupante devido a possibilidades desses organismos estarem resistentes a compostos como antibióticos. Todavia, para sobreviver ao ambiente inóspito, é importante que essa microbiota tenha desenvolvido um aparato enzimático específico que chama atenção e pode ser interessante para do ponto de vista biotecnológico.

\section{Leitura Complementar}

O leitor interessado numa revisão dos conceitos básicos sobre o tema aqui proposto, para a correta compreensão dos princípios que fundamentam os procedimentos, sugere-se a leitura da publicação:

"É veneno ou é remédio? Agrotóxicos, saúde e ambiente", PERES F, MOREIRA JC, Rio de Janeiro: Editora Fiocruz; 2003.

O leitor interessado também pode encontrar motivação para analisar dois textos clássicos relacionados ao uso da técnica aqui apresentada:

"Método químico de medição da respiração edáfica: alguns aspectos técnicos. Ciência e Cultura ", GRISI, B. M v.30, n.1, p.82-88, 1978. 
"In vitro susceptibility to antifungal agents of clinical and environmental Cryptococcus neoformans isolated in Southern of Brazil", ALVES, S. H, Revista do Instituto de Medicina Tropical de São Paulo, v. 43, n. 5, p. 267-270, 2001.

\section{Agradecimentos}

Consideramos essencial agradecer aos proprietários da propriedade de Hortaliças do bairro J Lima, que cedeu o terreno para a coleta do material para o experimento.

\section{REFERÊNCIAS}

CLARK, F.E. Agar-plate method for total microbial count. Pp. 1460-1466, 1965. In: C.A. Black; D.D. Evans; J.L. White; L.E. Ensminger; F.E. Clark \& R.C. Dinaver (eds.). Methods of soil analysis, Part 2. Chemical and microbiological properties. New York, Madson Inc., 1995

FARIAS, R. et al. Development of cross-resistance by Aspergillus fumigatus to clinical azoles following exposure to prochloraz, an agricultural azole. BMC Microbiology 14: 155; 2014.

SIQUEIRA, J. et al. Microrganismos e processos biológicos do solo: perspectiva ambiental. EMBRAPA, ministério da cultura, do abastecimento e da reforma agrária

NAKAGAWA, L. M; ANDRÉA, M. M. Efeito de alterações nas características do solo sobre a degradação de hexaclorobenzeno._Seção IX - Poluição do solo e qualidade ambiente. 2004

PEREIRA, J. C, NEVES, M., DROZDOWICZ, A. Quantificações Das Populações De Bactérias Em Geral, De Bactérias Resistentes a Antibióticos e de Actinomicetos em Solos, Seropédica, RJ 1996

RODRIGUES, H. B., et al. Variabilidade quantitativa de populações microbiana observada em solo de floresta tropical úmida, associada às condições microclimáticas.

Disponível

em: http://www.cbmet2010.com/anais/artigos/76_91999.pdf. A Amazônia e o clima global. Anais. Acesso em: ago, 2017.

SANTOS, A. P. A; BATISTA, S. B. Isolamento e caracterização fenotípica de microorganismos isolados de solo poluído por resíduos sólidos do bairro carrapicho município de Várzea Grande - Mato Grosso. Connection Line, Várzea Grande, v. 12, p. 29-43, 2015. 


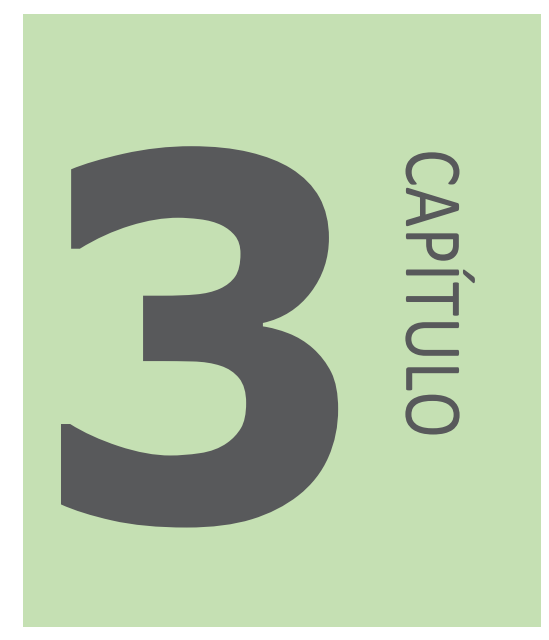

\section{AGROTÓXICOS NO MARANHÃO E A RESPONSABILIZAÇÃO POR DANOS À SAÚDE}

Claudson Santos Gomes ${ }^{1}$;

Dagolberto Calazans Araujo Pereira²

${ }^{1}$ Discente do Mestrado de Meio Ambiente da Universidade Ceuma

${ }^{2}$ Docente do Mestrado de Meio Ambiente da Universidade Ceuma 


\section{RESUMO}

Este capítulo tem como principal finalidade apresentar o diagnóstico dos agrotóxicos no Estado do Maranhão e a Responsabilização por danos à saúde. Os agrotóxicos também conhecidos como agroquímicos ou pesticidas representam atualmente um problema de saúde pública e ao meio ambiente. No Estado do Maranhão a problemática não é diferente, pois são utilizados de forma indiscriminada e sem segurança causando impactos à saúde humana, ao trabalhador rural que se expõe de forma direta e à população que pode estar consumindo um contaminante de forma silenciosa. É um produto químico altamente persistente no meio ambiente e de bioacumulação. Sua toxicidade varia de pouco tóxico a altamente tóxico. Os órgãos de fiscalização precisam ser mais rígidos no controle e monitoramento deste produto, iniciando suas ações nos pontos de venda e distribuição do produto, o qual deve ser comercializado somente com um receituário agronômico, emitido por um Engenheiro Agrônomo responsável. Ainda assim, outro problema está no período de carência do produto que na maioria das vezes não é obedecido pelo produtor, e que neste momento expõe toda uma população quando consome alimentos que podem conter resíduos deste contaminante.

Palavras-chave: Saúde Coletiva. Poluição. Ambiente.

\section{INTRODUÇÃO}

O avanço da produção agrícola, em visível progressão geométrica a partir da segunda metade do século XX, proporcionou um crescimento econômico e científico sem precedentes. Tal crescimento produziu importantes avanços sociais, comprovados através do aumento na expectativa de vida do ser humano. Contudo, o aumento da expectativa de vida não foi precedido por condutas sustentáveis, conduzindo o planeta a uma situação limite (contaminação do ar, da água, dos alimentos, erosão dos solos, esquentamento, diminuição da camada de ozônio, aumento das radiações e perda da diversidade biológica), o que nos leva a refletir sobre o progresso, os riscos para o meio ambiente e as gerações futuras e a responsabilidade civil inerente à preservação do ambiente.

A ocorrência de expansão das áreas de agricultura sem o adequado planejamento territorial gerou aumento dos impactos causados pelo uso de agrotóxicos sobre o ambiente, contribuindo assim para a poluição do ar, do solo, das águas e a intoxicação dos homens e animais. Estamos vivenciando uma crise ambiental, resultado inerente de um ciclo de destruição dos recursos naturais não renováveis e da criação de resíduos não reciclados. 
O alarme no que diz respeito ao uso dos agrotóxicos nos ecossistemas e seu impacto na saúde humana foi ocasionado pela sua mobilidade e persistência no meio ambiente. A maior parte dos agrotóxicos utilizados em lavouras é capaz de bioacumular-se em diferentes organismos e passar anos para desaparecer, elevando seu percentual tóxico e contribuindo para a contaminação de alimentos, corpos d'água e do solo, de maneira lenta e silenciosa, mas sem diminuir sua letalidade (LIMA, 2010).

O aumento do uso exagerado de agrotóxicos nos alimentos vem preocupando cada vez mais a população, que desconhece a quantidade de agrotóxicos que está ingerindo. Estes atuam, diretamente, por meio do contato direto do organismo com as substâncias. Existem três principais vias responsáveis pelo impacto direto da contaminação humana: a ocupacional que se caracteriza pela contaminação dos trabalhadores que manipulam essas substâncias; a ambiental, que ocorre por meio de dispersão/distribuição dos agrotóxicos ao longo dos diversos componentes do meio ambiente; e a alimentar que se dá relacionada à ingestão de produtos contaminados por agrotóxicos (MOREIRA et al.,2002).

Quando os agrotóxicos são utilizados em quantidades acima da capacidade de suporte do meio ambiente, divergindo-se de sua finalidade, são capazes de ser quimicamente transformadas quando absorvidas pelas plantas ou por outros organismos do solo e que eventualmente, podem ser ingeridas através dos alimentos podendo também ser transportadas pelas chuvas para os corpos d'água e ainda ser volatizada para a atmosfera (ISMAEL et al., 2015).

No Brasil, segundo o Sistema Nacional de Intoxicações ToxicológicasSINITOX, foram notificados em 2009 aproximadamente um total de 11.641 casos de intoxicações agudas por agrotóxicos de uso agrícola, número que pode ser subestimado considerando-se a elevada subnotificação desses eventos no País (CORDEIRO, 2014).

O Maranhão é o segundo maior consumidor de agrotóxicos da região Nordeste e o nono no ranking nacional. Observa-se no estado, de modo semelhante ao comportamento nacional, o crescimento da taxa de consumo de agrotóxicos, sem aumento proporcional na área plantada. Segundo pesquisas realizadas, entre os anos de 2011 e 2012, a taxa de consumo quase triplicou, passando de $7,24 \mathrm{~kg} / \mathrm{ha}$ para $20,71 \mathrm{~kg} / \mathrm{ha}$ (SINDAG, 2011). 
Os efeitos à saúde causados pela exposição aos agrotóxicos podem ser agudos ou crônicos. Os efeitos agudos ocorrem a partir de uma única exposição e geralmente em doses altas, já efeitos passam a ser considerados crônicos a partir de exposições a doses baixas ao longo do tempo. Muitas intoxicações podem provocar diminuição das defesas imunológicas, anemia, impotência sexual, cefaleia, insônia, alterações de pressão arterial e distúrbios de comportamento (LEVIGARD; ROZEMBERG, 2001).

Uma das problemáticas que vem sendo discutida e pesquisada na atualidade no que tange a exposição dos organismos aos agrotóxicos, refere-se à contaminação por vias indiretas, onde os organismos se expõem aos agrotóxicos por meio de ingestão de água e alimentos contaminados.

\section{OS AGROTÓXICOS}

\section{Il.1 Agrotóxicos: Definição e Características}

Segundo a legislação vigente, agrotóxicos e afins são definidos como: [...] produtos e agentes de processos físicos, químicos ou biológicos, destinados ao uso nos setores de produção, no armazenamento e beneficiamento de produtos agrícolas, nas pastagens, na proteção de florestas, nativas ou plantadas, e de outros ecossistemas e de ambientes urbanos, hídricos e industriais, cuja finalidade seja alterar a composição da flora ou da fauna, a fim de preservá-las da ação danosa de seres vivos considerados nocivos, bem como as substâncias e produtos empregados como desfolhantes, dessecantes, estimuladores e inibidores de crescimento [...](Lei № 7.802, de 11 de julho de 1989).

Quando a agricultura deixou de ser somente para consumo próprio do agricultor, houve uma grande expansão na plantação e com isso também vieram uma serie de consequências, ou seja, houve o aumento no número de ervas invasoras ou daninhas, insetos e muitas outras pragas que viriam a destruir as plantações, e na tentativa de defender a agricultura contra pragas que atacavam as plantações, os agrotóxicos foram criados. A utilização de agrotóxicos teve início na década de 20 e, durante a segunda guerra mundial, eles foram utilizados até como arma química.

No Brasil, a sua utilização tornou-se evidente em ações de combate as pragas agrícolas na década de 60 . Alguns anos depois, os agricultores foram liberados a comprar este produto de outros países. Quando bem utilizados, os agrotóxicos impedem a ação de seres nocivos, sem estragar os alimentos. Porém, se os agricultores não tiverem alguns cuidados durante o uso ou 
extrapolarem no tempo de ação dos agrotóxicos, estes podem afetar o ambiente e a saúde.

Segundo Souza Cruz (1989), agrotóxicos são produtos ou substâncias oriundas de processos físicos, químicos ou biológicos. São destinados ao controle de pragas prejudiciais à saúde, setores de produção, armazenamento, beneficiamento de produtos agropecuários, pastagens, culturais florestais, meio urbano e industrial. Agrotóxico é um nome genérico dado aos venenos utilizados na agricultura sob o pretexto de exterminar pragas e doenças. Existe 0 eufemismo "defensivo" utilizado pelos que lucram com eles, que longe de defender, envenenam e poluem o meio-ambiente.

II.1.1 Tipos de agrotóxicos

Os agrotóxicos podem ser: pesticidas (ou praguicidas), fungicidas e herbicidas. Os pesticidas, mais especificamente, subdividem-se em:

1. Quanto à finalidade: aficida, ovicida, larvicida, raticida, formicida, acaricida.

2. Quanto à maneira de agir: de ingestão, de contato, microbiano, fumigante.

3. Quanto à origem: inorgânicos e orgânicos.

II.1.2 Modo de ação dos agrotóxicos nas pragas, nas plantas e no ambiente A ação dos agrotóxicos é dividida da seguinte forma:

- Ação de contato: caracteriza o modo de ação de um pesticida que age e é absorvido pela pele (tegumento) do inseto.

- Ação de ingestão: caracteriza o modo de ação de um pesticida que age e penetra no organismo por via oral.

- Ação de profundidade: caracteriza o modo de atuação de um inseticida que tem ação translaminar, ou seja, que aplicado na face de uma folha, exerce sua toxidez contra insetos alojados inclusive na outra face da folha. Esta ação também pode ser observada nos frutos, quando o pesticida atinge o interior dos mesmos por translocação, destruindo as larvas das moscas-da-fruta.

- Ação fumigante: caracteriza o modo de ação de um pesticida que age penetrando no inseto na forma de vapor através de suas vias respiratórias.

- Ação sistêmica: ação que é exercida por um pesticida que é absorvido por uma planta e translocado em quantidades suficientes para tornar o local de translocação tóxico para os insetos por um tempo ilimitado (SOUZA CRUZ, 1989). 


\section{II.1.3 Classificação toxicológica}

O agrotóxico tem sua classificação em função de sua DL50 (dose letal), que significa a quantidade de produto suficiente para causar a morte da metade das cobaias em teste, é expressa em miligramas de princípio ativo por quilogramas de peso vivo.

A classificação toxicológica dos agrotóxicos é expressa da seguinte maneira: - Classe toxicológica I (Rótulo Vermelho): Veneno no qual se encontram substâncias ou compostos químicos considerados "altamente tóxicos" para o ser humano. - Classe toxicológica II (Rótulo Amarelo): Veneno considerado "medianamente tóxico" para o ser humano. - Classe toxicológica III (Rótulo Azul): Veneno considerado "pouco tóxico" para o ser humano. - Classe toxicológica IV (Rótulo Verde): Veneno considerado "práticamente não-tóxico" para o ser humano.

\section{II.1.4 Período de carência}

Existe o período de carência que é o intervalo de tempo dado, em, dias que deve ser respeitado entre a última aplicação e a data da colheita. Todo o produto colhido sem respeitar o período de carência terá uma quantidade do veneno suficiente para intoxicar o consumidor ou a pessoa que a esta manuseando. Existe no receituário agronômico e na bula do agrotóxico o período de carência para cada cultura.

Há também o efeito residual que é o tempo que o princípio ativo do agrotóxico atua sobre a praga alvo. E o princípio ativo que seria a substância ou componente químico ou biológico que atua sobre a praga (FUNDACENTRO, 1981).

\section{II.1.5 Tipos de intoxicação}

Segundo o World Resources Institute, a maioria dos agrotóxicos comercializados nos países subdesenvolvidos consiste de organoclorados e carbamatos que são conhecidos por sua alta toxicidade (WRI, 1998). Para Waichman et al. (2003), a alta toxicidade de tais produtos, atrelada à falta de informações sobre possíveis riscos envolvidos na sua utilização e à carência de informações acerca da maneira correta de aplicá-los, é um fato que predomina entre 14 os agricultores e que tem sido responsável por altos graus de contaminação ao meio ambiente e à saúde humana. 
Neste sentido, o Manual de Vigilância da Saúde de Populações Expostas a Agrotóxicos, produzido pela Organização Pan-Americana de Saúde (OPAS, 1996), divide os possíveis danos à saúde humana causados pela utilização dos mesmos em três tipos de intoxicação: aguda, subaguda e crônica, de acordo com o tempo de exposição e a toxicidade das substâncias manuseadas.

Ainda de acordo a OPAS, os danos causados pela intoxicação por agrotóxicos variam muito, dessa forma, envolvem fatores que vão desde as características químicas dos produtos, perpassando pelas próprias características da pessoa exposta até as condições de exposição.

No mesmo sentido, Schafer et al. (1999) afirmaram que os efeitos subagudos causados pela utilização dos agrotóxicos, mesmo sendo difíceis de identificar, às vezes podem ser constatados e tratados apropriadamente. Não obstante, se é difícil diagnosticar os efeitos subagudos, os efeitos em longo prazo, causados pela intoxicação crônica, são muito mais complexos para diagnosticar com precisão, uma vez que tais intoxicações estão relacionadas a problemas como surgimento de câncer, defeitos de nascimento, danos ao sistema nervoso, entre outros, que podem se desenvolver após 15 ou até 30 anos decorridos da exposição aos produtos.

Além disso, o estabelecimento de doses letais para seres humanos é seguido de uma identificação dos níveis de toxicidade de cada produto. Schafer et al. indicam ainda que o trabalho na agricultura pode ser considerado uma modalidade de alta periculosidade, bastando analisar o exemplo dos Estados Unidos, onde a taxa de mortalidade entre os trabalhadores agrícolas em 1996 foi maior do que a dos trabalhadores das indústrias.

No Brasil, todo produto deve apresentar nos seus rótulos uma faixa colorida indicativa de sua classe toxicológica (OPAS, 1996). No que se refere à classificação quanto ao potencial de periculosidade ambiental, as tipologias existentes se baseiam em uma série de parâmetros que incluem: a taxa de bioacumulação, a persistência no meio ambiente, o tipo de transporte, o nível de toxicidade para diversos organismos e os potenciais mutagênico, teratogênico e carcinogênico.

Wilson \& Tisdell (2001) afirmaram que a presença de agrotóxicos no meio ambiente afeta grande número organismos vivos e não simplesmente as pragas agrícolas. Além disso, outras interferências ambientais provocadas pela 
ação dos agrotóxicos incluem: a quebra da matéria orgânica, a interferência na respiração 15 dos solos, a contaminação de recursos hídricos e o desequilíbrio biológico entre presas e predadores. A intoxicação pode ocorrer de duas formas. A crônica que é a intoxicação causada pela exposição de forma continuada ao agrotóxico, e com isso vai se acumulando no corpo da pessoa causando doenças, e às vezes levando a pessoa a óbito.

Também existe a intoxicação aguda que ocorre quando a manifesto durante ou após a exposição dos agrotóxicos, na maior parte das vezes levando o indivíduo a morte (SOUZA CRUZ, 1998).

II.2 Processos de absorção do agrotóxico no ser humano

O principal meio de absorção do agrotóxico no ser humano é através da pele, ou seja, dérmica. É nesse local que o agrotóxico penetra através dos poros ou ferimentos, seja pela falta de equipamento ou pelo uso incorreto desse equipamento individual. Pode ocorrer por respingos e vapores quando em contato direto com os olhos, e também se esfregar as mãos contaminadas.

Uma das partes do corpo que mais absorve agrotóxico é o couro cabeludo. A inalação também é um processo de absorção que pode ocorrer quando o produto é preparado em ambientes fechados ou que tenham uma má ventilação. Já a ingestão é pouco comum, acontecendo mesmo só em casos acidentais ou suicidas (PUGA et al., 1991).

II.3 Métodos preventivos para evitar a intoxicação

São necessários alguns métodos e cuidados antes, durante e após aplicação dos agrotóxicos. Primeiramente deve-se ler o rótulo, o receituário e a bula. Sempre utilizar equipamentos de proteção individual (EPIs) recomendados (macacão, botas, chapéu ou boné árabe, luvas, máscara e óculos), todos em bom estado de conservação e limpos.

Os EPIs não devem ser usados para outros fins, e deverão ser lavados separadamente. $\mathrm{O}$ aplicador deve encontrar-se em boas condições de saúde. $\mathrm{O}$ pulverizador deve estar em perfeitas condições de uso. Quanto ao preparo do agrotóxico deve ser feito ao ar livre, ou em lugar bem ventilado. Preparar só a quantia necessária que for utilizar no dia da aplicação. Ter cuidados em abrir embalagens, para evitar derramamento, respingos ou levantamento de pó. Tomar o devido cuidado após aplicação, de lavar o rosto e as mãos com água fria e sabão, antes fazer qualquer refeição ou fumar. Utilizar sempre escova para 
desentupir bicos do pulverizador, e jamais a boca. De preferência aplicar os agrotóxicos nas horas frescas e sem vento. Se durante aplicação, atingir alguma parte do corpo com o agrotóxico, lavá-la imediatamente. Após o término da aplicação do agrotóxico, tomar banho com água fria e nunca com água quente, pois a água quente faz abrir os poros da pele facilitando absorção do agrotóxico. E também vestir roupas limpas. Guardar em armários com cadeados as embalagens e os equipamentos de proteção, para que fiquem longe de crianças e animais. Respeitar o período de carência e evitar a entrada de pessoas ou animais em lavouras recém-tratadas (SOUZA CRUZ, 1998).

II.4 Aspectos legais e normas de segurança para o manuseio do agrotóxico

Nas mais antigas civilizações já eram encontradas as proteções ambientais, pois a ação dominadora do ser humano sobre a terra é tão antiga quanto a sua existência. A evolução do Direito Ambiental no Brasil tem como referência e também supostamente como partida, as primeiras leis de proteção ambiental vinda com os europeus.

Nosso país, assim como os demais, tem certa proteção contra os seus recursos naturais da devastação e da degradação, assim sendo, quando o Brasil foi descoberto, já existia uma expressiva legislação de proteção ao meio ambiente. O Brasil tem ótimas leis ambientais que poderiam ser aplicadas, e ao mesmo tempo direcionadas para um processo transformador que beneficie a sociedade brasileira em seu amplo aspecto tecnológico, sem comprometer o ambiente e a biodiversidade nele existente (CARLI, 2004).

O maior problema é que essas leis não são cumpridas de maneira correta, principalmente quando se refere aos agrotóxicos, na qual possui uma legislação específica que regulamenta seu uso em todo território nacional, a Lei no . 7.802, de 11 de Julho de 1989 que dispõe sobre a pesquisa, a experimentação, a produção, a embalagem e rotulagem, o transporte, o armazenamento, a comercialização, a propaganda comercial, a utilização, a importação, a exportação, o destino final dos resíduos e embalagens, o registro, a classificação, o controle, a inspeção e a fiscalização de agrotóxicos, seus componentes e afins, e dá outras providências. Parte dessa lei foi regulamenta pelo Decreto ํo. 3.179, de 21.09.1999, que dispõe sobre a especificação das sanções aplicáveis às condutas e atividades lesivas ao meio ambiente e alterada pela Lei 9.974 , de 06 de junho de 2000, que trata especificamente sobre o 
destino das embalagens vazias. E também outros decretos como o Decreto $\mathrm{n}^{\circ}$. 4.074, de 04 de Janeiro 2002.

A análise da evolução histórica da legislação de agrotóxicos também demonstrou o crescente envolvimento e responsabilização dos diversos segmentos da sociedade (fabricantes, agricultores, comerciantes, etc), envolvidos com a questão dos agrotóxicos. A legislação atual dispõe de forma mais rigorosa e restritiva sobre o tema, o que pode contribuir para propiciar maior proteção à qualidade do meio ambiente desde que seja adequadamente aplicada e fiscalizada. Entretanto, deve-se destacar o avanço ocorrido nas últimas décadas e os esforços que têm sido feitos no sentido de cuidar da saúde humana e o meio ambiente.

O desafio atual é conseguir efetivar a harmonização da legislação de maneira a garantir o uso seguro, eficaz e econômico, com vistas a uma maior competitividade da produção agrícola (ALBUQUERQUE, 2003).

\section{OS AGROTÓXICOS NO ESTADO DO MARANHÃO}

O Maranhão possui uma área territorial de $331.937,45 \mathrm{~km}^{2}$ e um total de área plantada de $4.519 .305 \mathrm{~km}^{2}$ (CENSO, 2010). População de 6.574 .789 habitantes (IBGE, 2010), distribuídos em 217 municípios e 19 regiões de saúde que tem como função auxiliar os municípios na descentralização das ações de saúde.

O Estado tem como principais atividades, a agricultura e a pecuária, predominando a agricultura familiar, com baixa produção de alimentos e caracterizada por pequenas propriedades rurais, mas que utiliza diversas classes de agrotóxicos para a proteção de suas lavouras. O Estado do Maranhão apresenta uma área com pouco mais de 1 bilhão de hectares explorados predominantemente sob regime de agricultura familiar, possui 361 mil estabelecimentos agrícolas, sendo $80 \%$ menores que 20 hectares, dos quais $62 \%$ são menores do que dois hectares. A população estadual é de, aproximadamente, 6,57 milhões de habitantes, sendo 3,94 milhões (60\%) localizados na zona urbana e 2,62 milhões $(40 \%)$ na zona rural. Destes, 1,3 milhões estão ocupados em atividades agrícolas, sendo 39\% na qualidade de 
proprietários e 37\% na condição de ocupantes, 18\% como arrendatários e 6\% como parceiros (CENSO/IBGE, 2010).

Segundo dados SAGRIMA (2013), as principais culturas de lavoura, fava, feijão, mandioca, melancia, melão, milho, soja e tomate e de lavoura permanente: banana, borracha, castanha de caju, coco-da-baía, laranja, limão, mamão, manga, maracujá, pimenta do reino e urucum.

Segundo a Federação das Indústrias do Estado do Maranhão- FIEMA e a Secretaria de Estado de Meio Ambiente e Recursos Naturais- SEMA, o Maranhão não possui fábrica instalada de produtos agrotóxicos, entretanto, existem 429 estabelecimentos registrados para o comércio de agrotóxicos, 48 estabelecimentos prestadores de serviços na aplicação de agrotóxicos e 1.338 produtos agrotóxicos cadastrados na AGED, em 2013. Os quais são utilizados em diversas culturas agrícolas. Segundo o Sistema de Agrotóxico Fitossanitário (AGROFIT) do Ministério da Agricultura, Pecuária e Abastecimento (MAPA) são apresentados no quadro abaixo os principais agrotóxicos utilizados no Estado do Maranhão.

\section{Quadro 1- Principais agrotóxicos segundo ingredientes e grupos químicos utilizados no Estado do Maranhão.}

\begin{tabular}{|c|c|}
\hline Ingrediente & Grupo químico \\
\hline acefato & organofosforado \\
\hline atrazina & triazina \\
\hline azoxistrobina & estrobilurina \\
\hline ciproconazol & triazol \\
\hline carbendazim & benzimidazol \\
\hline clorpirifós & organofosforado \\
\hline dibrometo de diquate & bipiridílio \\
\hline dicloreto de paraquate & bipiridílio \\
\hline epoxiconazol & triazol \\
\hline piraclostrobina & estrobilurina \\
\hline fluroxipir-meptílico & ácido piridiniloxialcanóico \\
\hline picloram & ácido piridinocarboxílico \\
\hline glifosato & glicina substituída \\
\hline glifosato-sal de amônio & glicina substituída \\
\hline glifosato-sal de isopropilamina & glicina substituída \\
\hline glifosato-sal de isopropilamina & glicina substituída \\
\hline glifosato-sal de isopropilamina & glicina substituída \\
\hline glifosato-sal de potássio & glicina substituída \\
\hline glifosato-sal de potássio & glicina substituída \\
\hline Iufenurom & benzoiluréia \\
\hline profenofós & organofosforado \\
\hline malationa & organofosforado \\
\hline mancozebe & alquilenobis (ditiocarbamato \\
\hline metanol & álcool alifático \\
\hline metomil & metilcarbamato de oxima \\
\hline metarhizium anisopliae & biológico \\
\hline metolacloro & cloroacetanilida \\
\hline metomil & metilcarbamato de oxima \\
\hline metoxifenozida & diacilhidrazina \\
\hline picloram-trietanolamina & ácido piridinocarboxílico \\
\hline picloram-trietanolamina & ácido piridinocarboxílico \\
\hline 2,4-D-trietanolamina & ácido ariloxialcanóico \\
\hline protioconazol & triazolinthione \\
\hline trifloxistrobina & estrobilurina \\
\hline sulfluramida & sulfonamida fluoroalifática \\
\hline tiofanato-metílico & benzimidazol \\
\hline 2,4-D & ácido ariloxialcanóico \\
\hline 2,4-D-dimetilamina & ácido ariloxialcanóico \\
\hline 2,4-D-trisopropanolamina & ácido ariloxialcanóico \\
\hline
\end{tabular}


Fonte: AGROFIT, 2016.

Ressalta-se que no Maranhão não é admitido o uso de aeronaves na aplicação do herbicida, Glifosato, no plantio de soja por determinação do Ministério Público Federal.

Figueiredo, et al (2011) aponta em seu estudo que as principais exposições a estes produtos ocorrem nos setores agropecuários, de saúde pública, empresas dedetizadoras, de transporte, comercialização e produção de agrotóxicos. Além da exposição ocupacional, a contaminação alimentar e ambiental coloca outros grupos em risco de intoxicação, como famílias dos agricultores, moradores próximos às unidades produtivas e a população em geral, que se alimenta do que é produzido no campo.

\section{CONCLUSÕES}

Portanto, assim como em várias regiões do Brasil, no Maranhão o uso de substâncias químicas, dentre elas o agrotóxico, constitui-se como um grave problema de saúde pública, necessitando urgentemente de intervenção, visto que o uso inadequado dessas substâncias e a exposição da população pelo consumo de água e alimentos contaminados têm causado alterações do equilíbrio ecológico.

Nesse sentido, torna-se imprescindível a existência de uma vigilância em saúde de forma efetiva e integrada, contribuindo para o controle da morbimortalidade decorrente da exposição às substâncias químicas, e também para o desenvolvimento de um modelo agrícola ecológico e sustentável para o Maranhão. Estende-se ainda a grande preocupação com os profissionais de saúde (agentes de endemias) que atuam no controle vetorial nos municípios do estado e que estão diretamente expostos a essas substâncias.

\section{V- LEITURA COMPLEMENTAR}

O leitor interessado numa revisão dos conceitos básicos sobre o tema aqui proposto, para a correta compreensão dos princípios que fundamentam os procedimentos, sugere-se a leitura da publicação:

"Agrotóxicos no Brasil um guia para a ação em defesa da vida". Flávia Londres, Rio de Janeiro, 2011. 


\section{REFERÊNCIAS}

ANVISA. Programa de Análise de Resíduo de Agrotóxicos em Alimentos (PARA). Relatório de atividades 2011 e 2012. Gerência Geral de Toxicologia, Brasília, 29 de outubro de 2013. Acesso em: 25 nov. 2014.

CORDEIRO, T.A. O que você precisa saber sobre a água de João Pessoa. Editora Ideia, João Pessoa, 2014, 196p.

LIMA, N. C. Avaliação do impacto da contaminação do colo de áreas agrícolas de bom repouso (MG) por meio de ensaios ecotoxicológicos. Dissertação (Mestrado em Ciências de Engenharia Ambiental), São Paulo, 2010, 130p.

MOREIRA, J. C.; JACOB, S. C.; PERES, F. Avaliação integrada do impacto do uso de agrotóxicos sobre a saúde humana em uma comunidade agrícola de Nova Friburgo, RJ. Ciência e Saúde Coletiva. 2002; 7(2):p. 299-311.

Secretaria de Estado da Saúde. Plano Integrado de Vigilância em Saúde de Populações Expostas a Agrotóxicos. Secretaria Adjunta de Vigilância em Saúde. São Luís, 2014.

SINITOX- Sistema Nacional de Informações Tóxico- Farmacológicas. Casos registrados de intoxicação humana por agente e região, Brasil. 2011. $<$ http://www.fiocruz.br/sinitox novo/media/Tabela\%203.pdf> Acesso em: 26 mai. 2014.

VIGNA, C. R. M. Aplicação de Polissiloxanos Imobilizados sobre Sílica como Fase Estacionária e como Sorvente na Determinação de Agrotóxicos em Água e Caldo de Cana. Tese (Doutorado em Química). Universidade Estadual de Campinas, Instituto de Química, Campinas- SP, 2010, 137p. 


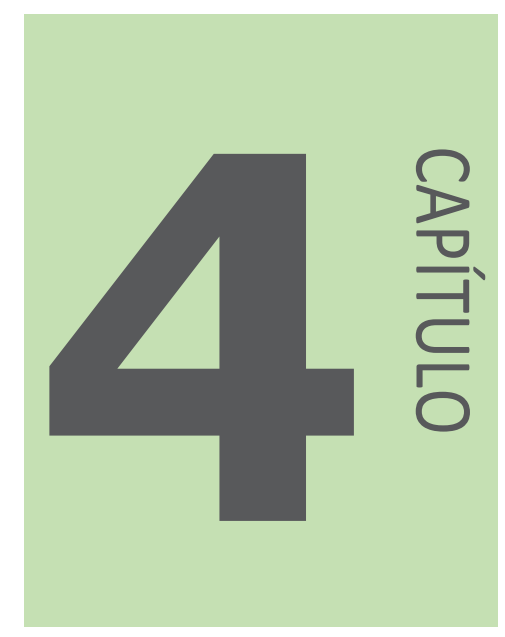

\title{
ANÁLISE DE TOXICIDADE DE EFLUENTES GERADOS NA ATIVIDADE DA CARCINICULTURA NA CIDADE DE BACABEIRAS-MA
}

\author{
Wellington de Sousa Monteles ${ }^{1}$ \\ Ábia de Jesus Martins ${ }^{2}$ \\ Queren Hapuque da Silva Costa ${ }^{3}$ \\ Thayná Fernandes Barros ${ }^{4}$ \\ Rita de Cássia Mendonça de Miranda ${ }^{5}$ \\ Luís Cláudio Nascimento da Silva ${ }^{6}$ \\ ${ }^{1}$ Instituto Federal de Educação, Ciências e Tecnologia do Maranhão \\ 2, 3, 4, 5, 6 Universidade CEUMA - UniCEUMA
}




\section{RESUMO}

A carcinicultura é o cultivo de camarão em cativeiro e é o segmento da aquicultura que mais cresce no mundo. Porém, os problemas ambientais causados pela carcinicultura vão desde a construção dos viveiros até despesca do camarão, onde todo o volume do tanque é esvaziado e os efluentes da etapa de engorda são lançados em rios, lagos e córregos, sem tratamento e sem observar os padrões de toxicidades estabelecidos por lei para lançamento de efluentes. O objetivo do estudo foi avaliar a toxicidade de efluentes líquidos coletado em fazenda de carcinicultura empregando modelo in vivo da larva Tenebrio molitor, relacionando-o com os paramentos físico-químicos analisados. Primeiramente, foram coletadas duas amostras do efluente do empreendimento de carcinicultura, uma no interior do viveiro (Efluente I), e o outro no canal, após a despesca (efluente II). Foram realizados as análises dos paramentos físicoquímicos, os quais ficaram acima do permitido pela resolução do CONAMA/2005, após isso foram feitos teste de toxicidade utilizado a larva do Tenebrio molitor. Os resultados obtidos demonstraram que existe uma diferença significativa entre os dois efluentes, uma vez que após 10 dias, a taxa de sobrevivência das larvas de Tenebrio molitor para o efluente I foi de $50 \%$, enquanto para o efluente II a taxa de sobrevivência foi de $80 \%$. Após observação dos resultados das taxas de sobrevivência das larvas de Tenebrio molitor, concluir-se que o efluente I apresentou uma maior toxicidade em relação ao efluente II, conclui-se também que os indicadores físico-químicos de qualidade dos efluentes da fazenda de camarão mostraram-se inadequados, a luz da legislação, para o lançamento do efluente no corpo receptor, havendo a necessidade de tratamento prévio dos efluentes gerados da atividade de carcinicultura, procurando reduzir, principalmente, a DBO e os compostos nitrogenados.

Palavras-chave: Poluição. Ambiente. Efluente.

\section{INTRODUÇÃO}

\section{I.1 A carcinicultura no Brasil e no Mundo}

A produção de pescado no mundo é subdividida em pesca e aquicultura. A pesca, de acordo com a finalidade econômica e social, pode ser considerada como amadora industrial ou artesanal (Brasil, 2013). A Aquicultura pode ser definida como a extração de organismos aquáticos do hábitat onde eles vivem, como rios, lagos, oceanos e mares, para fins como alimentação, recreação, ornamentação e para a fabricação de insumos para a indústria de ração animal (Oliveira \& Santos, 2011).

Atualmente, as possibilidades concretas de expansão do setor pesqueiro natural estão praticamente esgotadas, pois mais de $52 \%$ dos estoques mundiais 
de pescado já foram explorados, o que pode num futuro não distante acarretar na falta destes produtos a população mundial (FAO, 2014).

A aquicultura tornou-se uma alternativa para o suprimento deste mercado que apresenta tendência crescente devido ao fato do pescado representar um alimento saudável e de elevado interesse pela população em todas as faixas de renda (Brasil, 2011).

A aquicultura é um dos setores de produção de alimentos que mais cresce no mundo. Em 2012, ela estabeleceu a maior produção de todos os tempos e agora fornece quase metade de todo o pescado para a alimentação humana. Esta proporção deverá aumentar para 62\% até 2030 (FAO, 2014).

Dentre os diversos ramos da aquicultura, a carcinicultura, que é o cultivo de camarão em cativeiro, é o que mais cresce no mundo (Queiroz et al, 2013).

A carcinicultura é uma atividade de produção de alimentos que tem como pontos positivos a geração de emprego e renda e a diminuição da pressão sobre a exploração da pesca. (Tuna \& Taglidatto, 2015).

Atualmente, o Brasil ocupa o sexto lugar na lista mundial de produtores de camarão (Brasil, 2011), ficando atrás apenas da China, Tailândia, Vietnã, Índia e da Indonésia (Rocha, 2015). O Brasil tem como principais consumidores a França, o Japão e a Espanha, que juntos importam 96\% do que é produzido no país (Brasil, 2011).

O cultivo de camarões começou no início da década de 1970, e a produção cresceu vertiginosamente após esse período (Sebrae, 2015). Ainda que a atividade tenha sido iniciada no começo da década de 1970 no Rio Grande do Norte, somente após o desenvolvimento do pacote tecnológico do camarão branco do pacífico (Litopenaeus vannamei), entre 1996 e 1997, é que um crescimento mais intenso ocorreu (Queiroz et al., 2013). Segundo Meireles et al (2007), o crescimento da produção foi vigoroso até o ano de 2004 e se deu em muitos aspectos nos moldes do que já havia ocorrido nos países do sudeste asiático, sem ordenamento adequado, sem regulamentação, com forte incentivo governamental e geração de impactos ambientais e sociais graves.

Depois de mais de 20 anos do início da produção comercial da espécie L. vannamei no Brasil, e apesar de sua extraordinária adaptabilidade às mais diversas condições, inclusive às águas continentais do nosso país, da mesma forma que vem ocorrendo no Continente Asiático, podemos observar que as 
excepcionais características do solo e do clima do Nordeste são altamente favoráveis e atrativas para o desenvolvimento dessa atividade, mesmo com outras regiões do Brasil apresentando condições favoráveis para esse desenvolvimento (ABCC, 2013).

Os recursos naturais do Nordeste são de tal modo favoráveis e atrativos que ali está situada a quase totalidade dos empreendimentos da cadeia produtiva do camarão, em comparação com as demais regiões brasileiras, ou seja, o cultivo do camarão permanece, praticamente, dentro das fronteiras do Nordeste, entre a Bahia e o Maranhão, concentrando mais de $99 \%$ da produção nacional. (Rodrigues \& Borba, 2012).

Apesar do enorme potencial que detém o Maranhão para a carcinicultura, o desenvolvimento desta atividade em seu território é ainda incipiente. Houve, inclusive, uma redução dos cultivos entre os levantamentos de 2004 e 2011. São quatro os municípios maranhenses nos quais estão instaladas as cinco unidades produtivas do Estado, são eles: Apicum Açu, Água Doce, Bacabeiras e Turiaçi, e que ocupam uma área total de 151 hectares e que produziram, em 2011, 253 toneladas. As fontes de captação de água para abastecimento dos viveiros são de origem estuarina e de rio. Ao comparar o Maranhão com as demais Unidades Federativas que produzem camarão, pode-se constatar que a totalidade de seus empreendimentos conta com o licenciamento ambiental, fato esse que ocorre apenas nos Estados do Pará, Alagoas e Rio Grande do Sul (Brasil, 2013).

\section{I.2 Impactos ambientais gerados na pratica da carcinicultura}

Uma das contribuições de maior relevância da carcinicultura brasileira para a socioeconomia de suas zonas de intervenção é a capacidade do agronegócio de gerar emprego permanente, beneficiando as populações locais mais carentes do meio rural, representadas, no caso da região Nordeste (Rocha, 2002), porém, a carcinicultura não é apenas dados positivos, geração de emprego e renda. Para Ribeiro et al (2014), a busca pela prosperidade e lucratividade das atividades de carcinicultura, somada, muitas vezes, à ineficiência dos órgãos de governo nas atividades de licenciamento e fiscalização, e a não observância e/ou a permissividade das legislações ambientais podem levar a atividade de carcinicultura a causar uma série de impactos socioeconômicos e ambientais. 
Segundo Fabiano (2004), no mesmo momento em que a carcinicultura aumenta a área de aquicultura e gera emprego, ela enfrenta conflitos com a poluição das águas, salinização dos lençóis freáticos, a destruição de manguezais, os riscos da introdução de espécies exóticas e difusão de epidemias e a desestruturação das comunidades de pescadores artesanais.

Para Figueirêdo (2006), os problemas ambientais causados pelo cultivo do camarão vão desde a etapa da construção dos viveiros, onde ocorre o desmatamento, a limpeza do terreno e a escavação para construção dos tanques até a etapa da despesca do camarão, onde todo o volume do tanque é esvaziado e os efluentes contínuos da etapa de engorda são lançados em rios, lagos e córregos da região, sem tratamento prévio e sem observar os padrões estabelecidos por lei para lançamento de efluentes.

Além disso, a quantidade de nutrientes descartados diretamente no ambiente sem tratamento prévio, oriundos do acúmulo de restos de alimentos, fezes e fragmentos de animais nos fundos dos tanques, pode causar deterioração das águas dos corpos receptores e/ou sua eutrofização (Ribeiro et al 2014). A ração é o principal agente poluidor na carcinicultura. Mesmo se abastecido em quantidade e forma correta, calcula-se que apenas 17 a 25\% da ração fornecida, sejam efetivamente transformados em alimento. O restante, na forma de ração ou de excretas do camarão, deposita se no fundo do viveiro, favorecendo para a deterioração da qualidade da água, pelo aumento da carga orgânica e, consequente aumento da demanda bioquímica de oxigênio (DBO) (Figueiredo, 2006).

Segundo a resolução CONAMA (Conselho Nacional do Meio Ambiente) de número 357, de 17 de Março de 2005, as águas da União (doces, salobras e salinas) requerem níveis de qualidade e avaliações realizadas em condições e padrões específicos para garantir seus usos preponderantes e estabelece, a cada classe, a verificação do possível efeito tóxico (agudo ou crônico) a organismos aquáticos, demonstrando uma preocupação e um controle crescente com o despejo de efluentes, incluindo a Ecotoxicologia como uma forte ferramenta utilizada para indicação de qualidade de água.

\section{3 Caracterização físico-química do efluente de Carcinicultura}

De acordo com a Resolução № 312 de 2012 do CONAMA (conselho Nacional do Meio Ambiente), os empreendimentos de carcinicultura devem 
apresentar semestralmente o plano de monitoramento ambiental com os parâmetros de coleta, determinando a variação dos parâmetros físico-químicos coletados.

Até o presente, o controle de qualidade de efluentes líquidos é efetuado apenas por meio da determinação de parâmetros ambientais de natureza físicoquímica, e regulamentada por norma federal (CONAMA no 357, 2005) que estabelece padrões quantitativos de emissão (Costa et al, 2016).

Portanto, para fazer a análise dos paramentos físico-químico do efluente, foi feita uma visita ao empreendimento de carcinicultura, Dantas Camarões do Nordeste LTDA, localizado no município de Bacabeiras/MA, foram coletadas duas amostras, uma no interior do viveiro (Efluente I), e o outro no canal, após a despesca do camarão (efluente II), com a finalidade de caracterizar o resíduo líquido quanto à sua composição e propriedades, foram realizadas as seguintes análises físico-químicas: pH, DBO, DQO, condutividade, salinidade, turbidez, nitrato, nitrito, amônia, as análises seguiram os procedimentos analíticos baseados no Standard Methods, AWWA APHA WEF (2005), os resultados encontrados estão descritos na tabela I abaixo.

Tabela 1 - Parâmetros físico-químicos dos efluentes

\begin{tabular}{|c|c|c|c|}
\hline \multicolumn{4}{|c|}{ Análise dos paramentos físico-químicos de efluentes de carcinicultura } \\
\hline & Efluente I & Efluente II & $\begin{array}{l}\text { CONANA no } \\
357 / 2015\end{array}$ \\
\hline pH & 7 & 9,9 & Variação entre 6,5 a 8,5 \\
\hline Salinidade (\%) & 21 & 20 & $\begin{array}{c}\text { Superior a } 0,5 \text { e inferior } \\
\text { a } 30\end{array}$ \\
\hline $\begin{array}{l}\text { Condutividade } \\
(\mu \mathrm{S} / \mathrm{cm})\end{array}$ & 36,4 & 36 & *** \\
\hline Turbidez (UNIT) & 17,9 & 37,7 & *** \\
\hline DBO (mg/L) & 64,4 & - & Valor Max. 5,0 \\
\hline$D Q O(m g / L)$ & 783,8 & - & 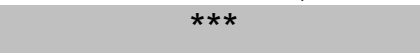 \\
\hline Nitrito (mg/L) & 1,06 & 0,08 & 0,07 \\
\hline Nitrato (mg/L) & 2,4 & 1,06 & 0,4 \\
\hline Amônia (mg/L) & 1,4 & 1 & 0,4 \\
\hline
\end{tabular}

*** Valores não disponíveis na resolução CONAMA no 357/2005

Os resultados dos paramentos de qualidade dos efluentes da fazenda de carcinicultura são apresentados na tabela XX, juntamente com os padrões de referência constante na resolução CONAMA no 357 de 2005, que trata das 
condições e padrões de lançamentos de efluentes para as águas salobras, classe 1, ou seja, aquelas destinadas à aquicultura e à atividade de pesca.

Em comparação com os valores de referência apresentados na resolução CONAMA 357/2005, todos os valores de parâmetros químicos (DBO, nitrito, nitrato e amônia), tanto do efluente I, quanto do efluente II, apresentaram valores em desacordo com os padrões e condições estabelecidos na resolução, ou seja, superiores àqueles recomendados para lançamento do efluente.

A Demanda Bioquímica de Oxigênio (DBO), que corresponde à quantidade de oxigênio consumido na degradação da matéria orgânica por processos biológicos, apresentou um valor muito acima do valor máximo estabelecido na resolução, o resto de ração, carcaça de animais mortos, bem como alguns agentes químicos como antibióticos depositados no viveiro, provavelmente, contribuíram para a deterioração da qualidade da água, pelo aumento da carga orgânica e, consequentemente, aumento da demanda bioquímica de oxigênio (DBO).

Alem disso, os processos bioquímicos de oxidação do amônio ao nitrito e deste para nitrato implicam o consumo de oxigênio dissolvido do meio, o que pode afetar a vida aquática quando a oxigenação do ambiente é menor que o consumo de oxigênio por esses processos (Pereira, 2004).

O nitrogênio é um dos elementos mais importantes do metabolismo de ecossistemas aquáticos e liberados na forma de nitrito, nitrato, amônia, nitrogênio orgânico dissolvido, etc. (Costa, 2013).

A principal fonte desses compostos nitrogenados é a decomposição e excreção dos animais aquáticos, restos dos alimentos não consumidos e decomposição da matéria orgânica (Aragão, 2008).

Ainda segundo Aragão (2008), o nitrato, nitrito e amônia são as formas mais tóxicas no nitrogênio no meio aquático.

De acordo com Pereira (2004), a toxidade do nitrato é em razão do seu efeito sobre a osmorregulação e possivelmente sobre o transporte de oxigênio. Quantidades excessivas de nitrato em águas de abastecimento podem causar o mal chamado metahemoglobinemia (síndrome de bebê azul), que pode acometer crianças de até três meses de idade; O nitrito em altas concentrações provoca a oxidação do átomo de ferro da hemoglobina, fazendo parar o 
transporte de oxigênio nos tecidos. Já Arana (1997), quantificou sete efeitos tóxicos da amônia, dentre eles: efeito sobre as células, excreção, respiração.

\section{4 Avaliação da toxicidade de efluente utilizado a larva Tenebrio molitor.}

A toxicologia estuda as substâncias tóxicas, naturais ou sintéticas, de pequeno ou grande peso molecular, avaliando as causas e os efeitos das toxinas e venenos de várias origens (vegetais, animais e minerais), bem como o tratamento indicado no caso de intoxicações (Larini, 1999).

A toxicidade de uma substância é avaliada pela sua capacidade de produzir lesões, sejam elas físicas, genéticas ou neuropsíquicas, com repercussões comportamentais (Kruger, 2009). A toxicidade aguda é caracterizada pelo aparecimento de sintomas já nas primeiras 24 horas após a exposição às substâncias e é sempre produzida por uma dose única, seja por via oral, dérmica ou inalatória (Larini, 1999). A toxicidade crônica ocorre quando os sintomas aparecem após as primeiras 24 horas, ou ainda após semanas ou meses da exposição às substâncias tóxicas. A toxicidade denominada recôndita é aquela que, embora induza a formação de lesões, não apresenta manifestações clínicas (Rosa, 2017).

Até o presente, o controle de qualidade de efluentes líquidos é efetuado apenas por meio da determinação de parâmetros ambientais de natureza físicoquímica, e regulamentada por norma federal (Conama, 2005) que estabelece padrões quantitativos de emissão. Entretanto, as análises químicas não levam em conta os possíveis efeitos associado à outras substâncias, em misturas complexas com o efluente, mostrando-se incapazes de possibilitar uma estimativa dos reais impactos biológicos ao ambiente (Nascimento, 2002).

Testes com organismos vivos podem responder às interações de substâncias químicas misturas complexas (Costa et al, 2016). Por esta razão, e em virtude de ainda não existirem padrões biológicos de toxicidade na norma legislativa, o objetivo deste trabalho foi utilizar um método biológico para avaliar a qualidade dos efluentes gerados nos empreendimentos de carcinicultura e relacionar os resultados desses com os resultados das análises físico-químicos.

$\mathrm{O}$ organismo teste aqui utilizado para detecção do efluente foi o modelo in vivo da larva do Tenebrio Molitor, que é um inseto que infesta grãos 
armazenados, possui tamanho avantajado e por isso suas larvas são bastante utilizadas para estudar a patogênese de fungos e bactérias (De Souza, 2015).

Esses modelos de hospedeiros de insetos possuem vantagens éticas, logísticas e econômicas em relação aos modelos de mamíferos (Li et al., 2013) e permitem testes de alta eficiência em larga escala e baixo custo (Lionakis, 2011), além disso, a larva do T. molitor pode ser mantida a temperaturas entre $25^{\circ} \mathrm{C}$ e $37^{\circ} \mathrm{C}$, o que a torna adequada para o estudo de patógenos à temperatura corporal ( $\mathrm{Li}$ et al. 2013). Outra importante vantagem refere-se à forma de inoculação, que é realizada por injeção através de seringas (MerkxJacques et al., 2013).

Para a avaliada da toxicidade de efluentes líquidos I e II, oriundos do empreendimento de carcinicultura localizado na cidade de Bacabeiras/MA, como já citado, foi empregando o modelo in vivo da larva Tenebrio molitor. Foram utilizadas 20 larvas em placas devidamente identificadas, e em seguida, $10 \mu \mathrm{L}$ dos efluentes I, II e o controle PBS foram inoculados nas larvas com o auxílio de uma seringa, as quais foram mantidas em temperatura ambiente e observadas a cada $24 \mathrm{~h}$ por um período de 10 dias.

Os resultados obtidos demonstraram que existe uma diferença significativa entre os dois efluentes, uma vez que após 10 dias, a taxa de sobrevivência das larvas de Tenebrio molitor para o efluente I foi de 50\%, levando em média seis dias para morrerem, enquanto para o efluente II a taxa de sobrevivência foi de $80 \%$, e com uma média de nove dias para as larvas morrerem, enquanto o controle PBS continuou inalterado, o gráfico I mostra bem essa diferença. 


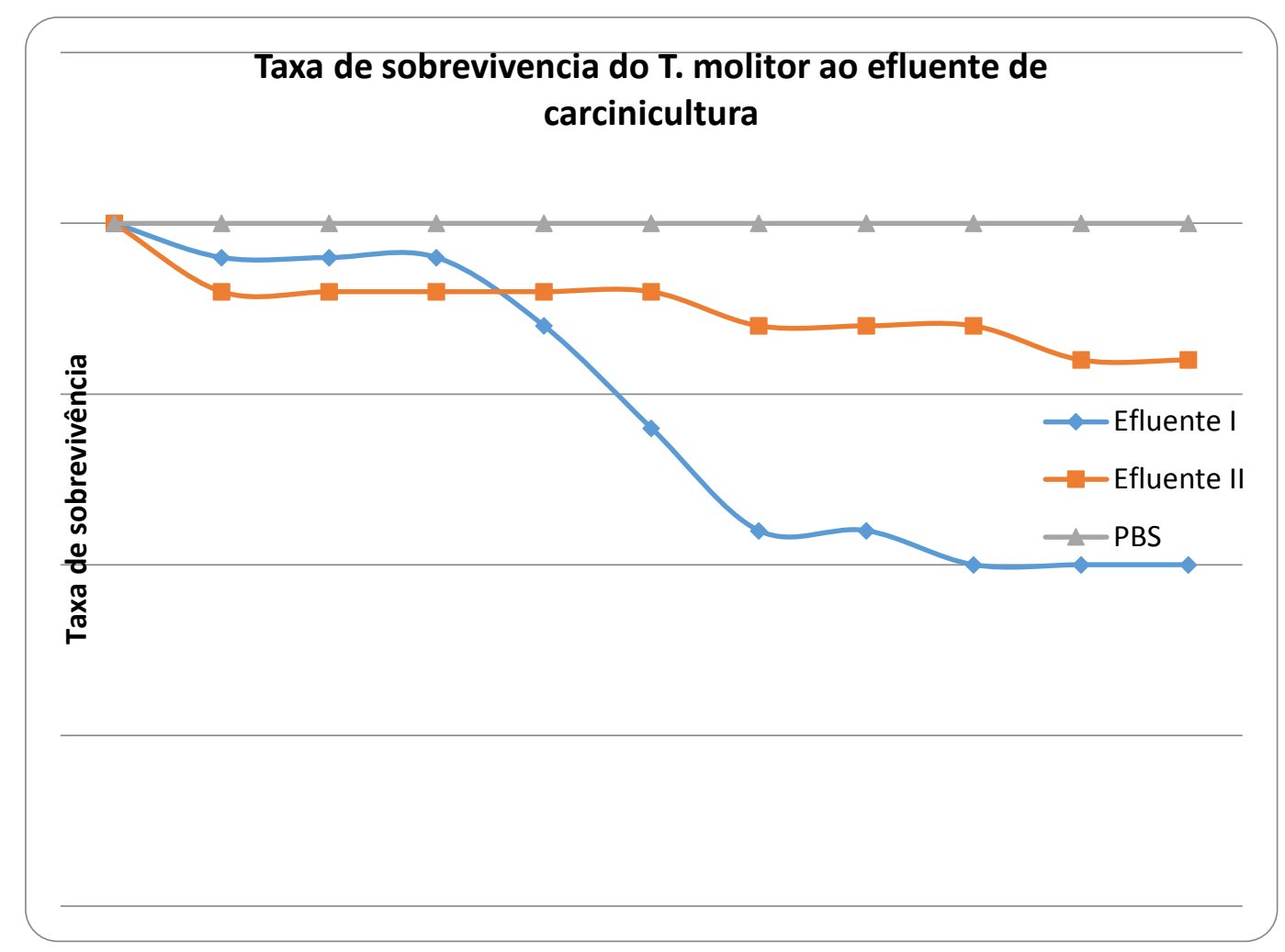

Grafico 1 - Taxa de sobrevivência da larva Tenebrio molitor

\section{CONCLUSÕES}

Após dez dias de observação das taxas de sobrevivência das larvas de Tenebrio molitor, os resultados obtidos dessa observação permitiram concluir que o efluente I demonstrou uma maior toxicidade deste em relação ao efluente II. Embora essa toxicidade não seja considerada aguda, pois embora os sintomas tenham aparecido nas primeiras $24 \mathrm{~h}$, as mortes formam ocorrendo aos poucos durante os dez dias, porém essa toxicidade se aproxima de uma toxicidade crônica que requer cuidados com o contato com o efluente. Cabe resaltar ainda que os indicadores físico-químicos de qualidade dos efluentes da fazenda de camarão mostraram-se inadequados, a luz da legislação, para o lançamento do efluente no corpo receptor, concluído por esse estudo a necessidade de tratamento prévio dos efluentes gerados da atividade de carcinicultura, procurando reduzir ao menos a DBO e os compostos nitrogenados. 


\section{LEITURA COMPLEMENTAR}

MANZANO, B. C. et al. Toxicologia e genética toxicológica. In: MarinMorales, M. A. A utilização de Allium cepa como organismos teste na detecção da genotoxicidade ambiental. São Paulo: UNESP, 2008, p. 1-6.

\section{REFERÊNCIAS}

ABCC - Associação Brasileira de Criadores de Camarão. Cultivo do Camarão Marinho: Realidade e verdades sobre a sua Sustentabilidade Ambiental e Contribuições para a Socioeconomia das Regiões e sua Intervenção. Revista da ABCC, Rio Grande do Norte, Edição Especial, ago. 2015.

ABCC - Associação Brasileira de Criadores de Camarão. Levantamento da Infraestrutura Produtiva e dos Aspectos Tecnológicos, Econômicos, Sociais e Ambientais da Carcinicultura Marinha no Brasil em 2011. Revista da ABCC, Rio Grande do Norte, [s.n], abr. 2013.

ARAGÃO, J. S. et al. Toxicidade do metabissulfito de sódio em Mysidopsis juniae. Arquivos de Ciências do Mar, v. 41, p. 24-29, 2008.

ARANA, L. V. Princípios químicos da qualidade da água em aquicultura. Florianópolis: Ed. da UFSC, 1997. 166p.

BRASIL - Ministério da Pesca e Aquicultura ( MPA). 2011- Boletim Estatístico da Pesca e Aquicultura. Brasil 2008-2009.

BRASIL - Ministério da Pesca e Aquicultura - MPA. 2013. Censo Aquícola Nacional. Disponível em: http://www.mpa.gov.br/images/Docs/Informacoes_e_Estatisticas/Censo_maio2 013-2.pdf.

CONAMA. Conselho Nacional do Meio Ambiente. Resolução № 357, de 17 de março de 2005. Dispõe sobre a classificação dos corpos de água e diretrizes ambientais para o seu enquadramento, bem como estabelece as condições e padrões de lançamento de efluentes, e dá outras providências. Diário Oficial, 17 mar 2005.

COSTA, W. Melo. et al. Remoção de compostos nitrogenados e fosfatados de efluentes por meio de reator anaeróbico com fluxo ascendente. Pesq. agropec. bras. [online]. 2013, vol.48, n.8, pp.1167-1170.

DE SOUZA, P. C. et al. Tenebrio molitor (Coleoptera: Tenebrionidae) as an alternative host to study fungal infections. Journal of microbiological methods, v. 118, p. 182-186, 2015.

FAO (Food and Agriculture Organization of the United Nations). Yearbook of fishery statistics: summary tables. FAO, Roma, 2009. 
FAO (Food and Agriculture Organization of the United Nations). The State of World Fisheries and Aquaculture - Opportunities and Challenges. Rome, 2014.

Fabiano, R. B. et al. Conflitos socioambientais e gestão integrada e sustentável de recursos pesqueiros. 2004.

FIGUEIREDO. M. C. B. et al. Impactos Ambientais da Carcinicultura de Águas Interiores. Revista Engenharia Sanitária e Ambiental, Rio de Janeiro, vol.11, ํㅜ, p. 231-240, jul. 2006.

KRUGER, R. A. Análise da toxicidade e da genotoxicidade de agrotóxicos utilizados na agricultura utilizando bioensaios com Allium cepa. Univ. Feevale, v. 58, 2009.

LARINI, L. Toxicologia dos Praguicidas. Manole editora. São Paulo. 1999, 230 p.

LI, D.D. et al. Using Galleria mellonella-Candida albicans infection model to evaluate antifungal agents. Biological and Pharmaceutical Bulletin, v. 36, n. 9, p. 1482-1487, 2013.

LIONAKIS, M.S. Drosophila and Galleria insect model hosts: new tools for the study of fungal virulence, pharmacology and immunology. Virulence 2, p. 521527, 2011.

MANZANO, B. C. et al. Toxicologia e genética toxicológica. In: Marin-Morales, M. A. A utilização de Allium cepa como organismos teste na detecção da genotoxicidade ambiental. São Paulo: UNESP, 2008, p. 1-6.

MEIRELES, A. J. A et al. Impactos ambientais decorrentes das atividades da carcinicultura ao longo do litoral cearense, nordeste do Brasil. Mercator-Revista de Geografia da UFC, v. 6, n. 12, 2007.

MEKRZ-JACQUES, A. et al. Evaluating the pathogenic potential of environmental Escherichia coli by using the Caenorhabditis elegans infection model. Applied and environmental microbiology, v. 79, n. 7, p. 2435-2445, 2013.

OLIVEIRA, E. G.; SANTOS, F. J. S. Conservação e uso racional de água: Integração aquicultura-agricultura. In: Medeiros, S. S. et al. (Eds.). Recursos hídricos em regiões áridas e semiáridas. Campina Grande: Instituto Nacional do Semiárido, 2011. p. 113-161.

PEREIRA, R. S. Poluição hídrica: causas e consequências. Revista Eletrônica de Recursos Hídricos, p. 20-36, 2004.

QUEIROZ, L. et al. Shrimp aquaculture in the federal state of Ceará, 1970-2012: Trends after mangrove forest privatization in Brazil. Ocean \& Coastal Management, v. 73, p. 54-62, 2013. 
RIBEIRO, L. F. et al. Desafios da carcinicultura: aspectos legais, impactos ambientais e alternativas mitigadoras. Journal of Integrated Coastal Zone Management / Revista de Gestão Costeira Integrada, [s.l], p. 365-383, abr. 2014.

ROCHA, I. P. A Indústria Brasileira do Camarão Cultivado. Revista da ABCC, Rio Grande do Norte, Edição Especial, maio. 2002.

ROCHA, I. P. Cultivo do Camarão Marinho: Realidade e verdades sobre a sua Sustentabilidade Ambiental e Contribuições para a Socioeconomia das Regiões e sua Intervenção. Revista da ABCC, Rio Grande do Norte, Edição Especial, ago. 2015.

RODRIGUES, J., BORBA, M. Carcinicultura Brasileira: Estatísticas e Revelações. Feed Food-ABCC, p. 40-42, 2012.

ROSA, P. A. F. et al. Biomonitoramento no córrego olaria, monte carmelo-mg utilizando o teste allium. Revista GeTeC, v. 6, n. 14, 2017.

SERVIÇO BRASILEIRO DE APOIO ÀS MICRO E PEQUENAS EMPRESAS SEBRAE. Aquicultura no Brasil - Série estudos mercadológicos. SEBRAE, 2015.

TAHIM, E. F. et al. A carcinicultura do nordeste brasileiro e sua inserção em cadeias globais de produção: foco nos APLs do Ceará. Revista de Economia e Sociologia Rural, v. 52, n. 3, p. 567-586, 2014.

TUNA, F. A. P.; TAGLIOLLATO, A. B. Um Breve panorama abordando aspectos positivos e negativos da maricultura. Revista Inovação, projetos e Tecnologias-IPTEC, São Paulo, vol.3, ํo3, p. 127-136, jan/jul. 2015. 


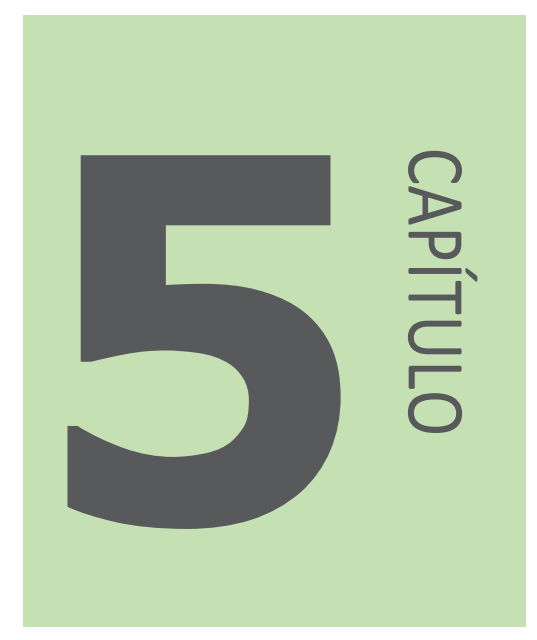

\section{PREVALÊNCIA DA SENSIBILIZAÇÃO DE PACIENTES ASMÁTICOS POR ALÉRGENOS AMBIENTAIS DERIVADOS DO DERMATOPHAGOIDES PTERONISSYNUS E BLOMIA TROPICHALIS.}

lêda Maria Silva Araújo ${ }^{1}$, Giselmo Pinheiro Lopes²,

Poliana Oliveira Lemos de Brito ${ }^{3}$,

Caroline Zilma Kalil de Paula Costa Pereira ${ }^{4}$, Maryângela Godinho Pereira Bena ${ }^{5}$, Angela Falcai ${ }^{6}$

1,2,3,4,5,6 Universidade CEUMA 


\section{RESUMO}

Atualmente cerca de 300 milhões de indivíduos da população mundial estão acometidos com asma. É uma doença inflamatória crônica, caracterizada por repetidas hipersensibilidade do tipo I. A afecção é decorrente da interação entre a predisposição genética e fatores ambientais. A exposição a aeroalérgenos ambientais presentes na poeira domiciliar, tais como, os ácaros da família Dermatophagoides pteronyssinus e Blomia tropicalis é um importante gatilho para 0 desencadeamento da asma. Analisar a prevalência da sensibilização de pacientes asmáticos por alérgenos derivados Dermatophagoides pteronyssinus e Blomia tropicalis. A pesquisa foi feita no Medline-PubMed e selecionou artigos publicados nos últimos 5 anos mediante a utilização dos descritores asthma, Der p, allergens; house dust; immunologic sensitization. Foram selecionados 22 artigos sobre alérgenos provenientes de ácaros encontrados no ambiente domiciliar e sua influência nos processos alérgicos e inflamatórios agudos e crônicos das vias aéreas.Pesquisas demonstram relação direta entre ácaros da poeira doméstica com manifestações alérgicas e com o desenvolvimento da asma. O Der $p$ é um dos alérgenos mais importantes nos fenômenos alérgicos nas regiões tropicais e subtropicais do mundo, sendo que o Der p1 e Blo t5 os mais imunogênicos. O ácaro Dermatophagoides pteronyssinus é o mais numeroso em casas européias. A Blomia tropicallis é uma espécie importante para os países tropicais e subtropicais como Brasil, Porto Rico e Colômbia. Na cidade de São Paulo, observou-se que as espécies $D$. pteronyssinus e B. tropicalis representam $50 \%$ e $26 \%$ dos alérgenos presentes na poeira domiciliar. Estudos nas cidades de Salvador, Recife e Rio de Janeiro, demonstraram que os ácaros dessas espécies também são os principais indutores da sensibilização alérgica e responsáveis pelas maiores porcentagens de frequência de testes cutâneos positivos. Uma alta prevalência da sensibilização aos alérgenos de ácaros em pacientes asmáticos.

Palavras-chave: Asma. Ambiente. Ácaros. Aeroalérgenos.

\section{INTRODUÇÃO}

Segundo o International Study of Asthma and Allergies in Childhood (ISAAC), numa perspectiva global, os países de língua inglesa e centros da América Latina destacam-se como os de maior prevalência para a doença. Tomando-se os dados obtidos no mundo todo, há uma variação de 20 vezes na prevalência de asma e de sintomas relacionados (oscilando entre 1,8 e 36,7\%), sendo os fatores ambientais os principais possíveis responsáveis por essa variação, constatação essa que estimulou a realização de uma série de estudos ecológicos na busca da compreensão dos mecanismos fisiopatológicos da doença.

No Brasil a asma é uma doença de alta prevalência, numa média de 
$23,3 \%$ para as crianças e de $22,7 \%$ para os adolescentes e, por seu impacto, deve ser encarada como problema de Saúde Pública. Em São Luís a prevalência em adolescentes se encontra próxima à média mundial e abaixo da encontrada no Brasil, não havendo diferença significante entre os sexos.

A asma é uma patologia que se caracteriza por episódios recorrentes de obstrução das vias aéreas cuja reversão pode ocorrer espontaneamente ou após o uso de medicação e está, geralmente, associada a hiperresponsividade brônquica e a processos inflamatórios crônicos das vias aéreas. As manifestações clínicas consistem em episódios recorrentes de sibilância, dispnéia, aperto no peito e tosse, agravam-se durante o período noturno ou início da manhã. Podem desaparecer durante alguns meses, no entanto as exacerbações podem ser graves. A maioria dos casos é leve, de resolução espontânea e de fácil manejo, embora possam existir casos de resistência ao tratamento, com necessidade de hospitalizações.

A classificação da gravidade da asma tem como principal função a determinação da dose de medicamentos suficiente para que o paciente atinja 0 controle no menor prazo possível. A avaliação usual da gravidade da asma pode ser feita pela análise da frequência e intensidade dos sintomas e pela função pulmonar.

A patogênese da asma é variada e há inúmeras vias biológicas, células inflamatórias e mediadores, com participação diferenciada, dependendo do fenótipo do paciente. O mecanismo de desenvolvimento de doenças alérgicas está relacionado à hipersensibilidade do tipo I com envolvimento dos linfócitos $T$ CD4+ (células $T$ helper) que desempenham um papel central como reguladores e efetores da resposta imune. Durante a última década, a compreensão da patogênese da asma passou por uma mudança significativa, a doença é caracterizada pela presença de células T- helper tipo 2 (Th2), há hiperplasia de células produtoras de muco e infiltração de células inflamatórias, com destaque para as células TCD4+, eosinófilos e mastócitos. O processo inflamatório alérgico é regulado pelas citocinas Th2, tais como a IL (Interleucina) -13, IL-4 e IL-5, sendo que as respostas Th2 podem ser controladas pelas células Treg.

O diagnóstico da asma deve ser baseado na anamnese, exame clínico e, sempre que possível, nas provas de função pulmonar e avaliação da alergia. De acordo com a IV Diretrizes Brasileiras para o Manejo da Asma são indicativos 
clínicos da doença: um ou mais dos sintomas dispnéia, tosse crônica, sibilância, aperto no peito ou desconforto torácico, particularmente à noite ou nas primeiras horas da manhã̃; sintomas episódicos; melhora espontânea ou pelo uso de medicações específicas para asma; três ou mais episódios de sibilância no último ano; variabilidade sazonal dos sintomas e história familiar positiva para asma ou atopia; e diagnósticos alternativos excluídos.

O diagnóstico funcional é dado pela espirometria e pelo pico de fluxo expiratório (PFE). Em indivíduos sintomáticos com espirometria normal e ausência de reversibilidade demonstrável ao uso de broncodilatador, o diagnóstico pode ser confirmado pela demonstração de hiperresponsividade das vias aéreas mediante a realização de testes de broncoprovocação com agentes broncoconstritores ou por exercício físico. O diagnóstico da alergia é feito através de testes cutâneos realizados com extratos com alérgenos biologicamente padronizados (prick teste). A determinação de IgE sérica específica confirma e complementa os resultados dos testes cutâneos.

O tratamento da patologia é direcionado para o controle dos sintomas e prevenção das exacerbações sendo indicados antiinflamatórios hormonais, broncodilatadores, mucolíticos, anticolinérgicos, anticorpos monoclonais anti-lgE e imunoterapia específica contra alérgenos. A introdução precoce do tratamento antiinflamatório com corticosteróides inalatórios resulta em melhor controle de sintomas, podendo preservar a função pulmonar em longo prazo e, eventualmente, prevenir ou atenuar o remodelamento das vias aéreas. $O$ tratamento ideal é o que mantém o paciente controlado e estável com a menor dose de medicação possível. Uma vez obtido o controle sintomático por um período mínimo de três meses, as medicações e suas doses podem ser reduzidas, mantendo-se o acompanhamento do paciente.

Dado o impacto de doenças alérgicas na Saúde Pública, diversos países têm realizados esforços para determinar a arquitetura genética de doenças complexas, assim como para investigar os efeitos conjuntos da genética e do ambiente na ocorrência dessas doenças. Tais estudos podem contribuir não apenas para a compreensão dos mecanismos causais biológicos, mas também para fundamentar o desenvolvimento das intervenções.

Dentre os fatores ambientais relacionados ao desencadeamento da asma, tem os ácaros, que são animais microscópicos pertencentes à ordem dos 
artrópodes. Taxonomicamente, são parentes e parecidos com os carrapatos, aranhas e escorpiões. Estão presentes de forma abundante na poeira doméstica, sendo mundialmente considerados desencadeantes de asma alérgica. São as principais causa de alergia respiratória, seguido por baratas e fungos. Atualmente de $1 \%$ a $2 \%$ da população mundial é afetada por alérgenos derivados de ácaros.

\section{OBJETIVOS}

Analisar a prevalência da sensibilização de pacientes asmáticos por alérgenos derivados Dermatophagoides pteronyssinus e Blomia tropicalis

\section{RESULTADOS}

Os ácaros são os principais alérgenos responsáveis pelo desencadeamento da asma alérgica. Eles estão presentes na poeira domiciliar, colchões, travesseios, tapetes e cortinas. $O$ ambiente favorável para 0 crescimento e desenvolvimento da fauna acarina é a umidade. A faixa de umidade ideal para o crescimento deve ser entre 55\% e 75\% e a temperatura entre $15^{\circ} \mathrm{C}$ e $35^{\circ} \mathrm{C}$. As condições climáticas locais também são fundamentais para o desenvolvimento dos ácaros e, associadas com características antrópicas, são responsáveis pela prevalência ou não de cada espécie. Uma alta densidade populacional associada com altitudes e condições climáticas adequadas é um ambiente propício para o desenvolvimento e reprodução dos ácaros.

Alguns ácaros do pó doméstico apresentam distribuição cosmopolita, como o Dermatophagoides pteronyssinus. Já a espécie Blomia tropicalis aparece muito em regiões tropicais e subtropicais. Entretanto, várias espécies apresentam distribuição regional, mas todas com potencial alergênicos. Os fatores bióticos e abióticos também podem influenciar na distribuição da fauna acarina nas residências em todo o mundo.

Estudos epidemiológicos indicam que o ácaro Dermatophagoides pteronyssinus é o mais numeroso em casas européias, enquanto o $D$. farinae é o mais comum em domicílios americanos. A Blomia tropicallis é uma espécie importante para os países tropicais e subtropicais como Brasil, Porto Rico e 
Colômbia. Na cidade de São Paulo, observou-se que as espécies $D$. pteronyssinus e $B$. tropicalis representam $50 \%$ e $26 \%$ dos alérgenos presentes na poeira domiciliar. Estudos nas cidades de Salvador, Recife e Rio de Janeiro, demonstraram que os ácaros dessas espécies também são os principais indutores da sensibilização alérgica e responsáveis pelas maiores porcentagens de frequência de testes cutâneos positivos.

Em uma meta-análise com 13.558 pacientes, de 16 países, observa-se uma alta prevalência de asma associada à sensibilização por ácaros domésticos (CALDERON et al.; 2015). Os alérgenos por eles liberados são produzidos 15 por células do trato intestinal, apresentam glicoproteínas e proteases de cisteína em sua composição. $O$ ácaro $D$. pteronyssinus é a principal fonte de alérgeno presente na poeira domiciliar e que pode ser identificado no mundo inteiro, sendo o Der $\mathrm{p} 1$ e Blo t5 os mais imunogênicos.

\section{CONCLUSÃO}

Trata de um dos principais problemas de saúde e ambiente. O Der é um dos principais aeroalérgenos envolvidos no desencadeamento da asma, sendo o Der p1 e Bl t 5 os alergenos mais imunogênico. Encontramos uma alta prevalência de pacientes asmáticos sensibilizados com os alérgenos de ácaros, principalmente Der p e Blo t. O conhecimento sobre a prevalência dos fatores de risco e de proteção da asma é de grande relevância para sociedade, uma vez que viabiliza o planejamento e o desenvolvimento de estratégias para o seu enfrentamento.

\section{REFERÊNCIAS}

BAQUEIRO, T. et al. Asthma and rhinitis symptoms in individuals from different socioeconomic levels in a Brazilian city. Allergy Asthma Proc, v.28, n.3, p.3627, May-Jun, 2007.

BERGMANN, K. C.;RAULFFS, M.; SANDER, I. House dust mites known to be an allergen source for 50 years: Der $p 1$ still detectable in the original sample. Allergo J Int, v.23, n.8, p.320-321, 2014.

BERTELSEN, R. J. et al. Clinical markers of asthma and IgE assessed in parents before conception predict asthma and hayfever in the offspring. Clin Exp Allergy, v.47, n.5, p.627-638, May, 2017. 
CHARPIN, D. High altitude and asthma: beyond house dust mites. Eur Respir J, v.40, n.6, p.1320-1, Dec, 2012.

FERGESON, J. E.;PATEL, S. S.; LOCKEY, R. F. Acute asthma, prognosis, and treatment. J Allergy Clin Immunol, v.139, n.2, p.438-447, Feb, 2017.

FUERTES, E. et al. Global Associations between UVR Exposure and Current Eczema Prevalence in Children from ISAAC Phase Three. J Invest Dermatol, v.137, n.6, p.1248-1256, Jun, 2017.

GIBSON, P. G.; MCDONALD, V. M. Management of severe asthma: targeting the airways, comorbidities and risk factors. Intern Med J, v.47, n.6, p.623-631, Jun, 2017.

HENSZEL, L.; KUZNA-GRYGIEL, W. [House dust mites in the etiology of allergic diseases]. Ann Acad Med Stetin, v.52, n.2, p.123-7, 2006.

JAIN, V. V.; STRINGER, W. Reassessment of an Asthma Diagnosis. JAMA, v.317, n.17, p.1801-1802, May 02, 2017.

JUST, J.;BOURGOIN-HECK, M.; AMAT, F. Clinical phenotypes in asthma during childhood. Clin Exp Allergy, Apr 19, 2017.

KOCZULLA, A. R. et al. New concepts in asthma: clinical phenotypes and pathophysiological mechanisms. Drug Discov Today, v.22, n.2, p.388-396, Feb, 2017.

KOPPELMAN, G. H.; GEHRING, U. Data-driven Asthma Phenotypes in Childhood. Does the Environment Hold the Clue? Am J Respir Crit Care Med, v.195, n.5, p.545-546, Mar 01, 2017.

LAU, M. Y. et al. The interaction between farming/rural environment and TLR2, TLR4, TLR6 and CD14 genetic polymorphisms in relation to early- and lateonset asthma. Sci Rep, v.7, p.43681, Mar 06, 2017.

LAWSON, J. A. et al. Prevalence, risk factors, and clinical outcomes of atopic and nonatopic asthma among rural children. Ann Allergy Asthma Immunol, v.118, n.3, p.304-310, Mar, 2017.

LIMA, W. L. et al. [Asthma and associated factors in students 13 and 14 years of age in Sao Luis, Maranhao State, Brazil]. Cad Saude Publica, v.28, n.6, p.1046-56, Jun, 2012.

MITCHELL, P. D.;EL-GAMMAL, A. I.; O'BYRNE, P. M. Anti-IgE and Biologic Approaches for the Treatment of Asthma. Handb Exp Pharmacol, v.237, p.131-152, 2017.

NAM, Y. H.; LEE, S. K. Comparison between skin prick test and serum immunoglobulin E by CAP system to inhalant allergens. Ann Allergy Asthma Immunol, v.118, n.5, p.608-613, May, 2017. 
PAGE, C.;O'SHAUGHNESSY, B.; BARNES, P. Pathogenesis of COPD and Asthma. Handb Exp Pharmacol, v.237, p.1-21, 2017.

PASHA, M. A.;SUNDQUIST, B.; TOWNLEY, R. Asthma pathogenesis, diagnosis, and management in the elderly. Allergy Asthma Proc, v.38, n.3, p.184-191, May 01, 2017.

RAYMOND, L. W. Reassessment of an Asthma Diagnosis. JAMA, v.317, n.17, p.1801, May 02, 2017.

REDDEL, H. K.;HURD, S. S.; FITZGERALD, J. M. World Asthma Day. GINA 2014: a global asthma strategy for a global problem. Int J Tuberc Lung Dis, v.18, n.5, p.505-6, May, 2014.

SHEMESH, E.; KLEINMAN, L. C. Asthma: The past, future, environment, and costs. J Allergy Clin Immunol, Apr 20, 2017.

SOLARZ, K.; BREWCZYNSKI, P. Z. [Biology of house dust mites (Acari: Astigmata: Pyroglyphidae)]. Wiad Parazytol, v.45, n.4, p.449-64, 1999.

SOLE, D. et al. Asthma in children and adolescents in Brazil: contribution of the International Study of Asthma and Allergies in Childhood (ISAAC). Rev Paul Pediatr, v.32, n.1, p.114-25, Mar, 2014.

STEINKE, J. W.; BORISH, L. Th2 cytokines and asthma. Interleukin-4: its role in the pathogenesis of asthma, and targeting it for asthma treatment with interleukin-4 receptor antagonists. Respir Res, v.2, n.2, p.66-70, 2001.

TO, T. et al. Global asthma prevalence in adults: findings from the crosssectional world health survey. BMC Public Health, v.12, p.204, Mar 19, 2012.

VISITSUNTHORN, N. et al. Comparison between specific lgE levels and skin prick test results of local and imported American cockroach, dog, cat, dust mites and mold allergen extracts. Asian Pac J Allergy Immunol, v.35, n.1, p.60-65, Mar, 2017.

WALSH, G. M. Biologics targeting IL-5, IL-4 or IL-13 for the treatment of asthma - an update. Expert Rev Clin Immunol, v.13, n.2, p.143-149, Feb, 2017. 


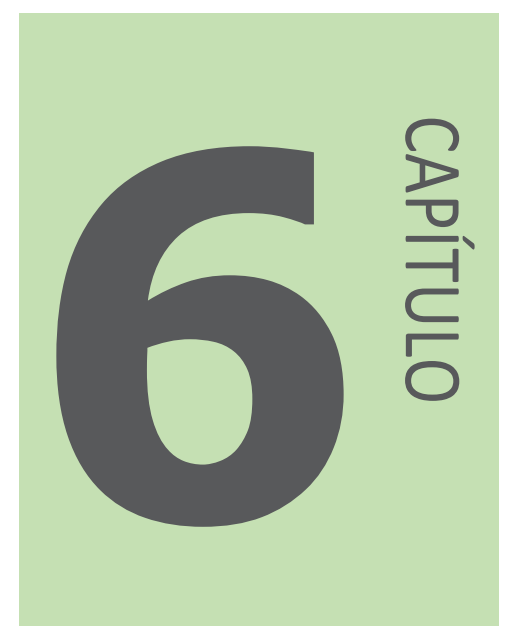

\section{RESISTÊNCIA CRUZADA ENTRE AGROTÓXICOS E ANTIFÚNGICOS DE USO CLÍNICO}

Letícia Chagas da Silva ${ }^{1}$;

Ione Cristine Silva de Araújo2;

Alessandra Teixeira de Macedo;

Joice Castelo Branco Santos ${ }^{4}$;

Julliana Ribeiro Alves dos Santos ${ }^{5}$

1,2.3,4,5Universidade Ceuma 


\section{RESUMO}

Com o advento da Revolução Verde, as atividades agrícolas ganharam maior importância e destaque no Brasil. Esta evolução foi acompanhada pelo incentivo a tecnologias com o objetivo de aumentar a produtividade e a competitividade brasileira. $\mathrm{O}$ aumento na produção agropecuária, no entanto, ocorreu sem considerar os impactos ao meio ambiente e à saúde humana. Um exemplo é o uso indiscriminado de agrotóxicos, os quais podem permanecer durante longos períodos no ambiente, podendo causar diversos danos ambientais e clínicos. Sabe-se que estes defensivos agrícolas causam impactos negativos no ambiente e na saúde humana. Além disso, podem exercer pressões seletivas na microbiota do solo, alterando diversas atividades metabólicas. Os fungicidas são amplamente empregados nas atividades agrícolas e por possuírem similaridade estrutural com alguns fármacos usados na clínica, podem contribuir para o desenvolvimento e propagação de estirpes resistentes. Como a fonte de muitas infecções fúngicas é ambiental, comumente são observados casos de resistência primária na clínica, sugerindo que os patógenos podem adquirir estes mecanismos ainda no ambiente. Neste contexto, o objetivo geral deste trabalho é destacar o impacto do uso de agroquímicos em fungos ambientais, principalmente quanto à patogenicidade e ao desenvolvimento de resistência cruzada a antifúngicos usados na clínica. Assim, considera-se que a resistência primária e o aumento da virulência de fungos ambientais possam ocorrer devido à exposição dos agentes patogênicos aos agroquímicos. A avaliação do impacto do uso de agrotóxicos é importante para reforçar a necessidade do uso consciente destas substâncias e para estimular a adoção de novas alternativas, como os biopesticidas.

Palavras-chave: Resistência. Agrotóxicos. Antifúngicos.

\section{Introdução}

Desde os primórdios da civilização, a agricultura representa a principal forma de relação do ser humano com a natureza, apresentando no tempo e no espaço, diferentes intensidades de impacto no meio ambiente. O processo de modernização agrícola, iniciado ainda no final do século XIX, com os avanços da energia a vapor, da mecânica, da genética vegetal e dos descobrimentos da química agrícola, apresentou continuidade nos setores agrícolas capitalizados. Este processo, apoiado por um conjunto de incentivos de políticas agrícolas nos Estados Unidos e Europa, que foi disseminado para os países em desenvolvimento, ficou conhecido internacionalmente por "Revolução Verde". Com o advento desta Revolução, o Brasil passou por grandes transformações, especialmente a partir da década de 50, o que gerou a intensificação no uso de agroquímicos, com o objetivo de prevenir ou controlar o crescimento de 
patógenos e consequentemente o aparecimento de doenças nas plantações. No entanto, a massificação do uso destas substâncias foi estimulada sem a preocupação e o acompanhamento prévio dos riscos ao meio ambiente e à saúde do produtor e do consumidor (FAIRBANKS, 2001; TAVELLA et al., 2011).

Desde 2008, o Brasil ocupa o primeiro lugar no ranking mundial de consumo de agrotóxicos. Nos últimos dez anos, o mercado mundial deste setor cresceu 93\%, enquanto no Brasil, esse crescimento foi de 190\%. De acordo com um levantamento feito pela Associação Brasileira de Saúde Coletiva (ABRASCO), anualmente, são usados mais de 850 milhões de litros de agrotóxicos, o que corresponde a uma exposição média ambiental/alimentar de mais de 4 litros por indivíduo.

O Estado do Maranhão é um dos 10 principais estados consumidores de agrotóxicos no país. De acordo com o SINAN, em 2013, foram registrados mais de 385 casos de intoxicação exógena, contudo, apenas 24 destes casos ocorreram devido aos agrotóxicos. Essas notificações, igualmente aos dados nacionais, não expressam o número real que provavelmente é bem superior ao registrado. Com a efetiva implantação das diretrizes e recomendações do Macrozoneamento Ecológico-Econômico do Estado do Maranhão (MZEE), espera-se que haja uma moderada diminuição no uso de pesticidas e herbicidas.

Alguns defensores do uso de agroquímicos afirmam que estas substâncias são seguras e os resíduos gerados além de mínimos, causam pouco impacto negativo ao ambiente. No entanto, os trabalhos científicos apontam que os efeitos agudos e crônicos gerados pelo uso de agroquímicos na saúde humana e no meio ambiente, mesmo aqueles classificados como menos tóxicos, são alarmantes e vão desde a manifestação de doenças neurológicas, endócrinas até mesmo ao surgimento de câncer. No ambiente, existe a possibilidade de contaminação da água, causando poluição nos mananciais e de interferir na respiração do solo, ciclagem de nutrientes e causar a mortandade de aves e peixes (TAVELLA et al., 2011).

Outro efeito negativo dos agroquímicos está diretamente associado ao surgimento e à propagação de fungos ambientais resistentes aos antifúngicos usados na clínica. As pressões ambientais causadas pelos antifúngicos agrícolas podem induzir à perda de vias metabólicas e selecionar micro- 
organismos com menor susceptibilidade à terapia antimicrobiana (CHOWDHARY et al., 2013; FARIA-RAMOS et al., 2014; BASTOS et al., 2017).

Embora alguns trabalhos tenham mostrado que os agroquímicos têm impulsionado o surgimento e a disseminação de estirpes resistentes, há uma escassez de dados em relação a ensaios de campo para estudar o impacto do uso, principalmente de azólicos agrícolas, no desenvolvimento de resistência aos antifúngicos de uso clínico, principalmente no Estado do Maranhão, que é um importante consumidor de agrotóxicos.

\section{Agrotóxicos de uso no Brasil}

Segundo a EMBRAPA, os produtos agrotóxicos são classificados em 4 níveis que variam de acordo com a toxicidade. São divididos em: classe I (que são os extremamente tóxicos, identificados pela faixa vermelha) até os produtos da classe IV (que são os produtos menos tóxicos, identificados pela faixa verde). A utilização do agrotóxico se dá em vários segmentos dos setores produtivos e mais intensamente pelo setor agropecuário, silvicultura, no tratamento de madeiras em geral, construção, armazenamento de grãos e sementes, produção de flores, além do combate de vetores transmissores de doenças. Segundo a Agência Nacional de Vigilância Sanitária (ANVISA), os agrotóxicos mais usados no Brasil são os herbicidas, que representam aproximadamente metade do consumo destas substâncias (48\%), entre os quais se destaca o glifosato. Em seguida, aparecem os inseticidas (25\%) e os fungicidas $(22 \%)$.

Os fungicidas consistem em um componente importante da produção agrícola, exercendo papel primordial principalmente no momento em que os demais métodos de controle mostram-se ineficientes. Sua intensa utilização vem provocando um sério problema, que é a resistência dos fungos a alguns princípios ativos. Quando se utilizam os fungicidas em um programa de manejo de doenças, é muito importante o conhecimento do mecanismo de ação das substâncias utilizadas, visando evitar erros que podem comprometer sua vida útil. Os triazóis agrícolas, como o epoxiconazol, também tem sido bastante utilizados no Brasil. As células fúngicas quando entram em contato com fungicidas triazóis acumulam esteróis com radical 14 a-metil, promovendo a inativação do processo de demetilação do lanosterol até compostos 
intermediários, precursores do ergosterol. A ausência deste constituinte e o aumento de compostos intermediários promovem uma desorganização da estrutura celular, induzindo à formação de membranas alternativas. A adição de ergosterol nestas células não reverte o processo, visto que as posições a ele destinadas são ocupadas por outros esteróis. Com doses elevadas de fungicida observa-se dano direto sobre a membrana, assim como alterações morfológicas no fungo (CHOWDHARY et al., 2013; FARIA-RAMOS et al., 2014).

\section{Infecções Fúngicas}

Muitos fungos apresentam potencial patogênico para os humanos. De acordo com os tecidos e órgãos afetados, as micoses são classificadas em: micoses superficiais, micoses cutâneas, micoses subcutâneas e micoses sistêmicas ou profundas. Além destas micoses, encontradas principalmente no hospedeiro hígido, as micoses chamadas oportunistas se caracterizam por serem causadas por fungos de baixa virulência, que convivem pacificamente com o hospedeiro, mas que, ao encontrar condições favoráveis, como distúrbios do sistema imunológico, metabólicos e iatrogenia, desenvolvem seu potencial patogênico, invadindo os tecidos e causando lesões (SIDRIM; ROCHA, 2004).

As infecções causadas por fungos representam um problema de saúde pública, uma vez que são doenças negligenciadas, subdiagnosticadas e, portanto, subestimadas. Dados do Sistema de Internação Hospitalar do Sistema Único de Saúde -SIH-SUS mostram que as principais micoses sistêmicas responsáveis por internações são a criptococose, a coccidiodomicose, a paracoccidioidomicose e a histoplasmose. Apesar da terapia antifúngica disponível, a morbidade e a mortalidade devido a estas micoses, principalmente em decorrência da resistência aos antimicrobianos, ainda é elevada com taxas que variam entre 30 a $80 \%$. A criptococose é a micose sistêmica mais prevalente em termos de internação (Ministério da Saúde, 2012) e a terceira infecção oportunista associada à AIDS (ALMEIDA; MACHADO, 2014). É desencadeada, principalmente por duas espécies, Cryptococcus neoformans e C. gattii que estão presentes em inúmeros nichos ambientais (troncos de árvores em decomposição, principalmente eucaliptos, solo, praças, restos de vegetais, 
poeira doméstica, excretas envelhecidas de aves, mais precisamente em espécies de Columba livia (COGLIATI et al., 2013).

Outra micose sistêmica responsável por internações é a coccidiodomicose, adquirida por meio da inalação de artroconídios de fungos do gênero Coccidioides, com dois principais representantes: $C$. immitis e $C$. posadasii, que são espécies saprófitas do solo. É uma infecção restrita a regiões de clima árido e semi-árido, principalmente solo alcalino e de baixo índice pluviométrico. No Brasil, o primeiro caso da doença foi descrito no final da década de 70 e desde então, foram descritos casos em regiões semi-áridas do Piauí, Bahia, Ceará e Maranhão, com microepidemias, principalmente entre os caçadores de tatu (AKRAM; KOIRALA, 2018b; MACÊDO et al., 2011).

A paracoccidioidomicose (PCM) é uma micose sistêmica, causada por Paracoccidioides brasiliensis ou $P$. lutzii que acomete órgãos como os pulmões e pode ser disseminada para outros sistemas. Esta é endêmica no continente Sul-Americano, com elevada incidência em trabalhadores rurais e parece estar mais bem associada com o solo e o cultivo de café, devido à maior incidência da doença em trabalhadores rurais na monocultura (MENDES et al., 2017).

A histoplasmose por sua vez, é uma micose sistêmica que tem como principal agente etiológico, Histoplasma capsulatum, presente em solo rico em excrementos de morcegos e pássaros. Tem larga distribuição mundial, com casos descritos em todo Brasil, porém o Estado do Rio de Janeiro é responsável pelo maior de número de relatos. A infecção também ocorre por via respiratória, por meio da inalação de propágulos fúngicos presentes no ambiente (AKRAM; KOIRALA, 2018a).

Um dos principais desafios em relação às micoses sistêmicas é o estabelecimento de uma terapia adequada após o diagnóstico que, na maioria das vezes, é tardio. As opções terapêuticas são restritas a poucas classes de antifúngicos como derivados azólicos, poliênicos, alilaminas e equinocandinas. Somado ao arsenal limitado de drogas, a resistência a estes fármacos limita a terapia antifúngica. Acredita-se que uma das causas da resistência aos antifúngicos esteja associada ao uso de agrotóxicos que causam uma pressão seletiva nos fungos presentes no ambiente e possibilitam a disseminação de estirpes resistentes aos antigúngicos de uso clínico (CHOWDHARY et al., 2013). 


\section{I.1.1. Agroquímicos e Antifúngicos de Uso clínico}

Uma das principais finalidades do uso de agroquímicos é inibir o crescimento de fungos que são patógenos freqüentes na agricultura. No entanto, como os fungos são organismos ubíquos, saprofíticos e estão presentes no ambiente associados ao solo, plantas e matérias em decomposição, neste ambiente, encontram-se também os principais agentes etiológicos de doenças no homem, como Aspergillus spp., Cryptococcus spp., Fusarium spp., Fonsecae pedrosoi, Paracoccidioides brasiliensis e fungos dermatófitos. A fonte de infecção de muitas micoses é ambiental e ocorre principalmente pelas vias áreas ou por inoculação, após algum trauma na pele ou nas mucosas (CHAYAKULKEEREE \& PERFECT, 2006).

Alguns agroquímicos pertencem ou possuem estruturas químicas e moleculares semelhantes a classes de antifúngicos usados na clínica, como por exemplo, o propiconazol, bromuconazol, tebuconazol, epoxiconazol e difenoconazol que são importantes triazólicos fungicidas agrícolas. Estes compostos possuem similaridade estrutural com azólicos clínicos, como fluconazol, voriconazol e itraconazol. O procloraz que é outro potente antifúngico usado na agricultura, recentemente, passou a ser proibido no Brasil pela ANVISA, motivado principalmente pela elevada toxicidade do produto (CHOWDHARY et al., 2013; FARIA-RAMOS et al., 2014).

Os azólicos interagem com um sistema enzimático microssomal dependente do citocromo P-450, mais especificamente, a enzima lanosterol 14 alfa-demetilase, a qual está envolvida com a síntese do ergosterol. Estas enzimas são codificadas pelo gene ERG11 (também conhecido como CYP51). Os fungos resistentes aos azóis podem apresentar uma alteração no sítio alvo da 14 alfa-demetilase. Mais de um terço do total de vendas de fungicidas é representado pelos azólicos (principalmente triazóis) e mais de $99 \%$ dos inibidores da demetilase são utilizados na agricultura. Atualmente, existem mais de 25 tipos de azólicos inibidores da demetilase para fins agrícolas, um número muito superior aos triazóis médicos licenciados para o tratamento de infecções fúngicas. Os azóis agrícolas podem persistir e manter-se ativo durante vários meses em muitos nichos ecológicos, tais como solo e ambientes aquáticos (CHOWDHARY et al., 2013; FARIA-RAMOS et al., 2014). 
Freqüentemente, 0 tratamento das micoses profundas começa empiricamente, uma vez que o diagnóstico pode ser difícil e habitualmente é obtido tardiamente. Alguns fatores contribuem para a dificuldade na escolha da droga e devem ser relevados como: os agentes são encontrados na natureza como formas de vida livre, em reservatórios animais e fazendo parte da microbiota normal do homem; são microrganismos de reprodução lenta; o tratamento geralmente é prolongado. Até a década de 80 , as opções terapêuticas para o tratamento de infecções fúngicas invasivas eram restritas, principalmente devido à elevada toxicidade dos antifúngicos. Atualmente, a terapia padrão com azólicos, polienos e equinocandinas é comumente utilizada para o tratamento de diferentes infecções fúngicas, embora nem sempre sejam efetivos contra isolados emergentes, principalmente em casos de resistência antimicrobiana (HATIPOGLU; HATIPOGLU, 2013).

\section{l.1.2. Resistência Cruzada entre agrotóxicos e antifúngicos clínicos}

A resistência aos antimicrobianos pode ser subdividida em primária, definida como uma resistência natural ou intríseca do organismo, ou secundária (adquirida) que é resultante da exposição a uma droga específica. Embora os isolados clínicos geralmente se apresentem como menos susceptíveis aos antifúngicos quando comparados aos fungos ambientais, CHOWDHARY et al. (2011) observaram por meio da avaliação do perfil de susceptibilidade de amostras ambientais e clínicas de $C$. gattii, que os fungos isolados do ambiente apresentavam uma menor susceptibilidade ao fluconazol, ao itraconazol e ao voriconazol, quando comparados aos isolados clínicos. Segundo CHOWDHARY et al. (2013), isolados de Aspergillus fumigatus resistentes aos azólicos clínicos obtidos de pacientes com aspergilose invasiva, sem tratamento prévio com azólicos, são adquiridos a partir de fontes ambientais.

A aplicação generalizada de fungicidas e a sua persistência no meio ambiente são forças seletivas significativas para o surgimento e a propagação de fungos resistentes aos antimicrobianos. Uma vez que vários fungos causadores de doença no homem compartilham seus ambientes naturais com muitos patógenos de plantas, estes micro-organismos estão expostos a uma pressão intensa e persistente de fungicidas (CHOWDHARY et al., 2013). Além do surgimento de isolados ambientais resistentes aos azólicos usados na clínica, 
também existe a possibilidade de desenvolvimento de resistência cruzada com outros antifúngicos clínicos, como a anfotericina $\mathrm{B}$, devido à redução nos níveis de ergosterol da membrana celular. Bastos et al. (2018) ao analisar o efeito do tebuconazol frente a isolados de Cryptococcus spp., observaram resistência ao fluconazol, itraconazol e ravuconazol, mas não à anfotericina B. Além dos efeitos na sensibilidade aos antifúngicos, o tebuconazol altera a morfo-fisiologia e virulência de Cryptococcus neoformans e $C$. gattii.

Um dos principais mecanismos de resistência aos azólicos é a modificação ou mutação na enzima alvo (14 alfa-demetilase) e/ou outras enzimas no mesmo patamar bioquímico. Outros mecanismos contribuem para a resistência às drogas como a redução do acúmulo da droga, que engloba o aumento da expressão com a ativação de bombas de efluxo; a alteração no alvo para impedir a ligação da droga, incluindo mutações e superexpressão do gene ERG11 (YANG; LO, 2001). A rápida disseminação de fungos resistentes tem dificultado a terapia antifúngica, principalmente o tratamento oral com azólicos, restando apenas opções mais tóxicas e administradas por via intravenosa, como a anfotericina $B$ e as equinocandinas que além de apresentarem efeitos colaterais indesejados e prejudiciais, podem ter sua atividade reduzida (CHOWDHARY et al., 2013).

\section{Conclusões}

As altas taxas de falhas terapêuticas que são frequentemente observadas após o uso de antifúngicos podem ser resultantes da aquisição de fungos resistentes a partir do ambiente. O uso indiscriminado de agrotóxicos, principalmente os azólicos agrícolas, contribui com a seleção de microorganismos resistentes às drogas antifúngicas. Considerando a necessidade de compreender o impacto do uso de agroquímicos na microbiota do solo e a relação com os insucessos terapêuticos na clínica, devido à resistência cruzada, espera-se fornecer dados e subsídios para o uso consciente destas substâncias e incentivar o uso de biopesticidas como alternativa aos produtos químicos. A conscientização acerca dos prejuízos causados pelos agroquímicos promove uma melhora na qualidade da saúde humana, com um melhor controle do 
desenvolvimento de resistência antimicrobiana e redução dos altos índices de morbidade e mortalidade associadas às infecções fúngicas invasivas.

\section{Leitura Complementar}

CHOWDHARY, A.; KATHURIA, S.; XU, J.; MEIS, J.F. Emergence of azole-resistant Aspergillus fumigatus strains due to agricultural azole use creates an increasing threat to human health. Plos Pathogens, v. 9, n. 10: e1003633, 2013.

\section{Agradecimentos} financeiro.

Os autores agradecem à Universidade CEUMA e à FAPEMA pelo auxílio

\section{REFERÊNCIAS}

AKRAM, S.M.; KOIRALA, J. Histoplasmosis. In: StatPearls [Internet]. Treasure Island (FL): Stat Pearls Publishing; 2018a.

AKRAM, S.M.; KOIRALA, J. Coccidioidomycosis. In: StatPearls [Internet]. Treasure Island (FL): StatPearls Publishing; 2018b.

ALMEIDA, R.L.G.; MACHADO, E.R. Cryptococcus spp. em pacientes com HIV/SIDA: Revisão da Literatura, Ensaios e Ciência: Biológicas, Agrárias e da Saúde, v. 18, n. 1, p. 55-63, 2014.

BASTOS, R. W. et al. Environmental triazole induces cross-resistance to clinical drugs and affects morphophysiology and virulence of Cryptococcus gattii and $C$. neoformans. Antimicrobial Agents and Chemotherapy, v. 62, n. 1, p 1-15, 2018.

CHAYAKULKEEREE, M.; PERFECT, J. R. Cryptococcosis. Infectious Disease Clinics of North America, v. 20, n. 3, p. 507-44, 2006.

CHOWDHARY, A. et al. In vitro antifungal susceptibility profiles and genotypes of 308 clinical and environmental isolates of Cryptococcus neoformans var.grubii and Cryptococcus gattii serotype B from north-western India. Journal of Medical Microbiology, v. 60, p. 961-967, 2011.

COGLIATI, M. Global molecular epidemiology of Cryptococcus neoformans and Cryptococcus gattii: An atlas of the molecular types. Scientifica, 675213, 2013.

FAIRBANKS M. Defensivos agrícolas ampliam o mercado. Revista Química e Derivados, v. 396: p. 398-403, 2001. 
FARIA-RAMOS, I. et al. Development of cross-resistance by Aspergillus fumigatus to clinical azoles following exposure to prochloraz, an agricultural azole. BMC Microbiology, v. 14: 155, 2014.

HATIPOGLU, $\mathbf{N}$; HATIPOGLU, $H$. Combination antifungal therapy for invasive fungal infections in children and adults. Expert Review of Antiinfective Therapy, v. 11, n. 5, p. 523-535, 2013.

MACÊDO, R.C. et al. Molecular identification of Coccidioides spp. in soil samples from Brazil. BMC Microbiology, 11:108, 2011.

MENDES, R.P. et al. Paracoccidioidomycosis: Current Perspectives from Brazil. The Open Microbiology Journal, v. 11, p. 224-282, 2017.

. Ministério da Saúde. Secretaria de Vigilância em Saúde. Vigilância e Epidemiológica da Criptococose. Brasília, 2012. 18 p.

SIDRIM, J.J.C.; ROCHA, M.F.G. Micologia Médica à luz de autores conteporâneos. Rio de Janeiro: Guanabara Koogan, 2004. 408 p.

TAVELLA, L. B. et al. O uso de agrotóxicos na agricultura e suas consequências toxicológicas e ambientais. Agropecuária Científica no Semiárido, Santa Cecília, v. 7, n. 2, p. 06-12, 2011.

YANG, Y.L.; LO, H.J. Mechanisms of antifungal agents resistance. Journal of Microbiology, Immunology and Infection, v. 34, n.2, p. 79-86, 2001. 


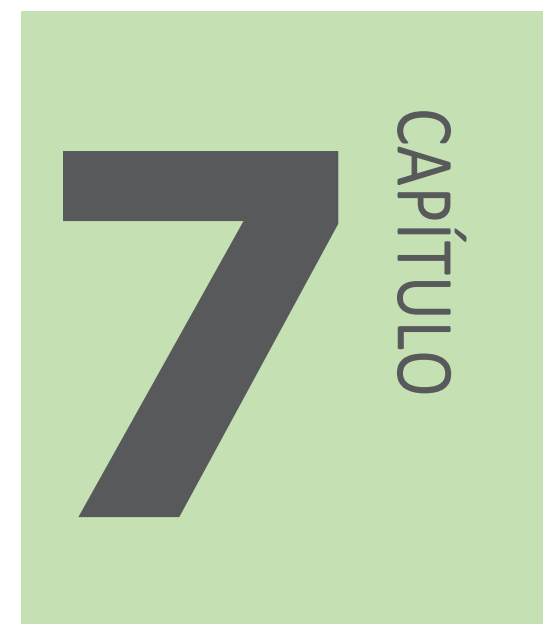

\section{SÍNTESE, CARACTERIZAÇÃO MOLECULAR E AVALIAÇÃO DA ATIVIDADE ANTIMICROBIANA DO TRIAZENO 1,3-BIS(2-METOXI-5-NITROFENIL) TRIAZENO.}

Jose Costa Sampaio Filho';

Ingrid Santos Gonçalves ${ }^{1}$;

Erima Joyssielly Mendonça Castro ${ }^{1}$;

Sielys dos Santos Amaral ${ }^{1}$;

Rodrigo Vieira Blasques²;

Luís Felipe Diniz Pereira ${ }^{3}$;

Rita de Cassia Mendonça de Miranda';

Patrícia de Maria Silva Figueiredo4;

Paulo Cesar Mendes Villis ${ }^{1}$

1;3;4 Universidade de CEUMA;

2;4 Universidade Federal do Maranhão 


\section{RESUMO}

Triazenos são compostos orgânicos de cadeia aberta contendo três átomos de nitrogênio ligados em sequência. Constituem uma classe de compostos químicos que apresentam a capacidade de se coordenar a diferentes centros metálicos levando a distintas geometrias de coordenação e comprovada atividades biológicas. Este trabalho descreve pela primeira vez a síntese e a estrutura molecular do triazeno simétrico 1,3-bis(2-metoxi-5-nitrofenil) triazeno (TZC). O TZC foi obtido a partir da diazotação da 2-metoxi-5-nitroanilina com nitrito isoamílico (2:1). O TZC foi encaminhado para teste da atividade antimicrobiana, mediante avaliação da sensibilidade da solução do composto frente às bactérias ATCC's (American Type Culture Collection, ATCC) e isolados clínicos, aplicando-se ensaios microbiológicos padronizados. Os resultados mostraram a potencialidade do composto em estudo, frente à resistência das cepas bacterianas selecionadas para realização dos testes.

Palavras-chave: Triazenos. Diazotação. Pseudomonas aeruginosa

\section{INTRODUÇÃO}

Os triazenos são compostos orgânicos, pertencentes à família dos compostos nitrogenados de cadeia aberta (alifáticas), caracterizados pelo grupo diazoamínico, e constituídos de três átomos de nitrogênio ligados em sequência (MOORE, 1986), conforme representa a Figura I.1.<smiles>[R]N=NN[R]</smiles>

(a)<smiles>[R]N=NN</smiles>

(b)

Figura I. 1. Representação estrutural genérica de triazeno simétrico (a) e assimétrico (b).

Os compostos triazenídicos mostraram-se bastante eficazes no desenvolvimento de compostos ou substâncias com atividades biológicas. Segundo KOEHLER et al. (2007) essa atividade biológica pode ser justificada, pois o grupo das aminas presentes nesses compostos são amplamente utilizadas em sínteses experimentais de novos compostos por possuírem sítios específicos de ação nas membranas celulares e capacidade de formar ligações de hidrogênio (KOEHLER, 2007).

A atividade antibacteriana de compostos triazenos tem sido pouco estudada e alguns autores avaliaram a atividade dos triazenos frente a bactérias e fungos. PARAGINSKI et al. (2014) avaliaram a atividade de 15 (quinze) 
compostos triazenídicos, incluindo um complexo de vanádio e um sal de potássio de um hidroxitriazeno, frente a várias bactérias, incluindo cepas ESBL ( $\beta$ lactamases de espectro ampliado). Tais compostos foram ativos frente a bactérias multirresistentes, incluindo cepas produtoras de ESBL, MBL (metalo$\beta$-lactamases) e do gene AmpC. Essas evidências tiveram grande impacto na atualidade, uma vez que esses mecanismos de resistência bacteriana estão entre os mais prevalentes.

Um dos usos mais difundidos dos triazenos é no desenvolvimento de moléculas que apresentem atividade biológica na terapia contra o câncer, como por exemplo o fármaco Dacarbazina ${ }^{\circledR}$, 5-(3,3-dimetil-1-triazeno) imidazol-4carboxiamida, conhecido como DTIC, que foi o primeiro triazeno a apresentar atividade antitumoral, relatado em 1962 por Shealy et al. (NEVES, 2011).

Este trabalho tem como objetivo principal sintetizar, caracterizar e avaliar a atividade biológica e antimicrobiana do TZC, empregando, para isso, ensaios microbiológicos padronizados.

\section{Il.1.1 Síntese do triazeno}

O TZC foi sintetizado pelo acoplamento de um sal de diazônio com uma amina aromática livre, descrito por HARTMAN et al. (1943), conforme a Figura I.2.

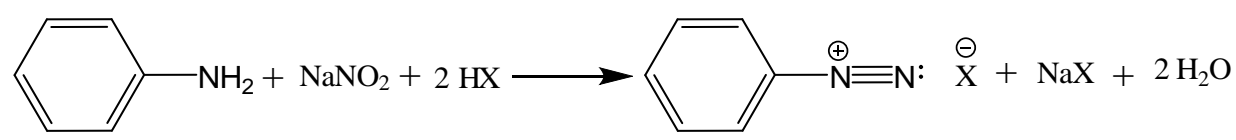

Figura I.2. Um mecanismo proposto para a diazotação (VERNIN, 1977).

\section{Il.1.2 Caracterização Estrutural}

As medidas de $\mathrm{AE} \mathrm{CHN}$ (Analise Elementar $\mathrm{CHN}$ ), para detecção dos teores de carbono, hidrogênio e nitrogênio contidos na amostra do TZC, foram determinadas no Analisador Elementar da Leco Instrumentos LTDA - modelo TruSpec CHNS-O.

Os espectros de IV (Espectroscopia de absorção na região do infravermelho) do TZC foram obtidos utilizando o equipamento da marca Shimadzu, modelo FT-IR-Prestige-21, Beam Splitter KBr (escala de varredura no IV de 7800 a $350 \mathrm{~cm}^{-1}$, detector DLATGS, resolução 0,85; 1; 2,4; 8 e $16 \mathrm{~cm}^{-1}$, interferômetro selado de Michelson com alinhamento dinâmico. 


\section{II.1.3 Bioensaios}

\section{II.1.3.1 Seleção de cepas bacterianas}

As amostras bacterianas foram oriundas do Laboratório de Microbiologia Clinica da Universidade Federal do Maranhão. Para realização dos testes, foram utilizados micro-organismos padrão ATCC e isolados clínicos. As amostras bacterianas empregadas foram:

- Shigella flexneri (Amostra de fezes 278)

- Streptococcus agalactiae (Secreção vaginal 12092294)

- Acinetobacter baumannii (Secreção traqueal 12337641)

- Staphylococcus haemolyticus (amostra de sangue 13084879)

- Proteus mirabilis (Secreção traqueal 557691)

- Staphylococcus epidermidis (amostra de sangue 13079158)

- Enterobacter cloacae (12330175)

- Morganella morganii (5721529)

- Staphylococcus saprophyticus (13087266)

- Serratia marcescens (12285366)

- Salmonela spp. (7855729)

- Pseudomonas aeruginosa (ATCC 27853)

- Staphylococcus aureus (ATCC 25923)

- Escherichia coli (ATCC 2592)

\section{II.1.3.2 Preparo das suspensões microbianas}

Os microrganismos foram inicialmente reativados a partir das suas culturas originais e mantidos em meio líquido $\mathrm{BHI}$ (Brain Heart Infusion) a $37^{\circ} \mathrm{C}$ por $24 \mathrm{~h}$.

\section{II.1.3.3 Preparo da solução triazeno (STZC)}

A solução triazeno foi preparada dissolvendo $0,1041 \mathrm{~g}$ de do triazeno 1,3-bis(2-metoxi-5-nitrofenil) triazeno em uma mistura de etanol absoluto e $\operatorname{DMF}(1: 100)$.

$\underline{\text { II.1.3.4 Macrodiluição em tubos com BHI e Concentração Inibitória Mínima (CIM) }}$ 
A determinação da CIM foi feita através da técnica de macrodiluição segundo a metodologia da diluição em caldo proposta pelo National Committee for Clinical Laboratory Standard (CLSI, 2016).

\section{Il.1.3.5 Controle dos ensaios antibacterianos}

Os controles positivos e negativos e do meio $\mathrm{BHI}$ foram utilizados para garantir a ausência de interferentes que alteram os resultados dos testes. No controle positivo, foram inseridos o meio de cultura $(\mathrm{BHI})$ e $30 \mu \mathrm{l}$ da suspensão bacteriana, o que constitui o controle do microrganismo. No controle negativo foi adicionado o meio de cultura e $1000 \mu \mathrm{l}$ da STZC, o que constitui o controle do produto.

\section{Il.1.3.6 Concentração Bactericida Mínima (CBM)}

Foram utilizados os tubos incubados para determinação da CIM em meio líquido para determinação da CBM.

\section{II.1.3.7 Teste de atividade hemolitica}

A atividade hemolítica foi ensaiada por incubação da STZC com $1 \%$ de eritrócitos (cavalo, carneiro e humano) adquirido comercialmente. A atividade hemolítica foi expressa como a concentração máxima da STZC que causou hemólise.

\section{II.2.1 Síntese do triazeno 1,3-bis(2-metoxi-5-nitrofenil) triazeno}

\section{Reação}
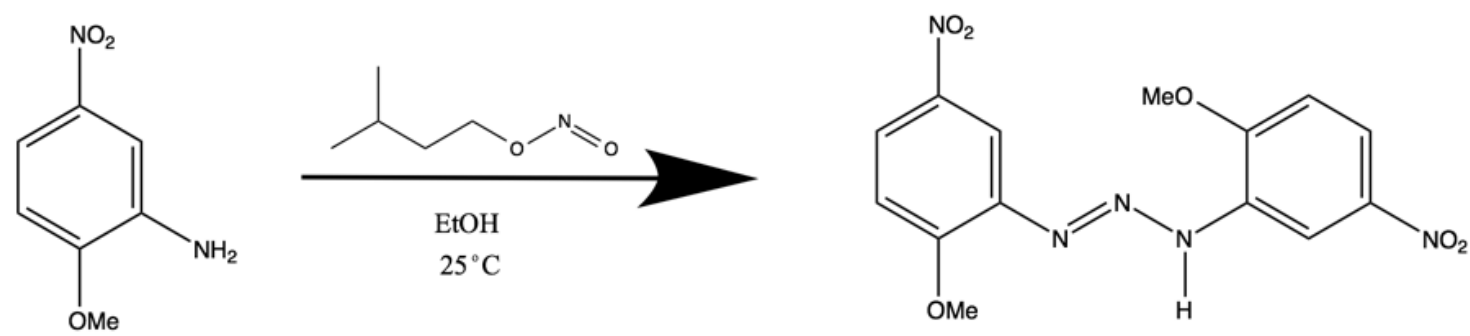

O triazeno 1,3-bis(2-metoxi-5-nitrofenil) triazeno foi obtido a partir da diazotação da 2-metoxi-5-nitroanilina (PF: $128-30^{\circ} \mathrm{C}$ ) com nitrito isoamílico, na proporção de 2:1.

Preparou-se uma solução contendo $0,50 \mathrm{~g}(2,97 \mathrm{mmol})$ de 2-metoxi-5nitroanilina, dissolvidos em $30,0 \mathrm{~mL}$ de etanol absoluto (EtOH), a qual se 
adiciona sob agitação magnética e temperatura ambiente, uma solução de nitrito isoamílico $\left(\mathrm{C}_{5} \mathrm{H}_{11} \mathrm{NO}_{2}, \mathrm{D}=0,872 \mathrm{~g} / \mathrm{mL}\right)$ com $0,20 \mathrm{~mL}(1,48 \mathrm{mmol})$. Observou-se a formação de um precipitado amarelo escuro, conforme mostra a Figura I.3. Separou-se o produto por filtração à vácuo e lavou-se o precipitado repetidas vezes com etanol. Por fim, secou-se o produto sólido amarelo escuro amorfo à temperatura ambiente.

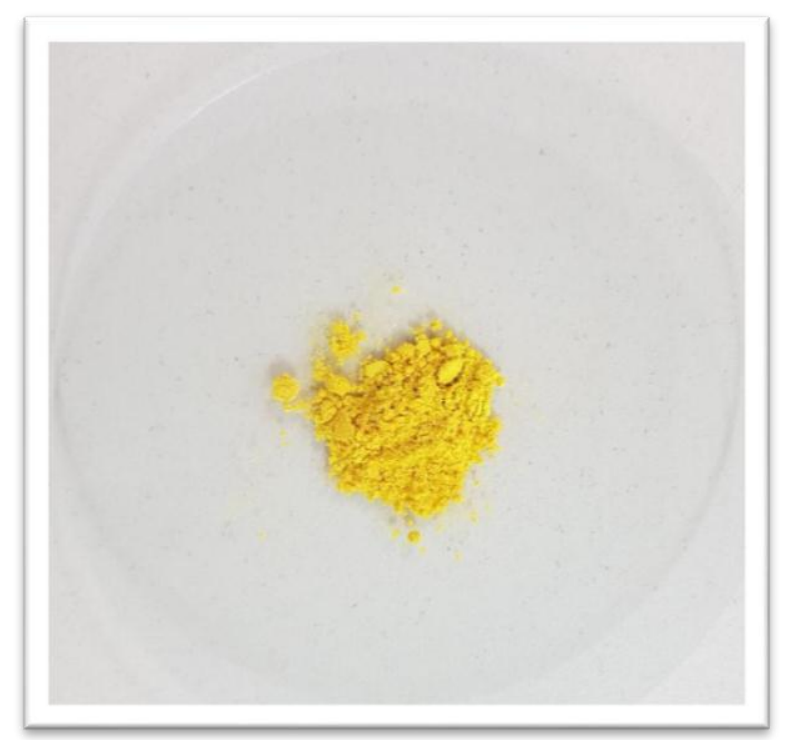

Figura I.3. Composto 1,3-bis(2-metoxi-5-nitrofenil) triazeno

Recristalização em uma mistura de THF/DMF $(30 \mathrm{~mL} / 10 \mathrm{~mL})$.

O produto sólido obtido foi solúvel em THF e DMF; parcialmente solúvel em $\mathrm{CH}_{2} \mathrm{Cl}_{2}$. Insolúvel em metanol, etanol, acetonitrila, acetato de etila e éter etílico.

II.2.2 Caracterização do triazeno 1,3-bis(2-metoxi-5-nitrofenil) triazeno

Rendimento Exp.: $0,34 \mathrm{~g}(58,24 \%)$

Rendimento Teor.: 0,58g

Análise Elementar (\%): $\mathrm{C}_{16} \mathrm{H}_{19} \mathrm{~N}_{5} \mathrm{O}_{7}: \mathrm{C}, 48,85 ; \mathrm{H}, 4,87 ; \mathrm{N}, 17,80$.

Experimental: $\quad \mathrm{C}, 48,84 ; \mathrm{H}, 4,57 ; \mathrm{N}, 17,75$.

P.F.: $208-210^{\circ} \mathrm{C}$

Espectroscopia de Infravermelho $\left(\mathrm{KBr}, \mathrm{cm}^{-1}\right): v_{\text {as }}(\mathrm{NH})=3324 \mathrm{~cm}^{-1} ; v_{\mathrm{s}}(\mathrm{C}-\mathrm{O}-$

C) $=1086 \mathrm{~cm}^{-1} ; v$ as $(\mathrm{C}-\mathrm{O}-\mathrm{C})=1254 \mathrm{~cm}^{-1} ; v\left(\mathrm{NO}_{2}\right)=1519 \mathrm{~cm}^{-1} ; v(\mathrm{C}=\mathrm{C})=1592$

$\mathrm{cm}^{-1} ; v(\mathrm{~N}=\mathrm{N})=1467 \mathrm{~cm}^{-1} ; v(\mathrm{~N}-\mathrm{N})=1164 \mathrm{~cm}^{-1} ; v(\mathrm{C}-\mathrm{N})=863 \mathrm{~cm}^{-1}$.

\section{Il.2.3 Determinação da Concentração Inibitória Mínima (CIM)}


Para a STZC, a menor CIM encontrada foi de 0,0059 para Acinetobacter baumannii e Streptococcus agalactiae e para as amostras de Escherichia coli e Staphylococcus haemolyticus foram de $0,0118 \mathrm{mg} / \mathrm{mL}$. Para Pseudomonas aeruginosa e Salmonella $0,0236 \mathrm{mg} / \mathrm{mL}$ e Staphylococcus aureus a CIM foi de 0,0946, conforme mostra a Tabela 1.

\begin{tabular}{lcc}
\hline $\begin{array}{l}\text { Tabela 1. Concentração inibitória mínima in } \\
\text { bacteriana de referência e isolados clínicos }\end{array}$ & & \\
\hline Microrganismos & CIM $^{1}$ & CN $^{2}$ \\
Acinetobacter baumannii & 0,0059 & 0 \\
Streptococcus agalactiae & 0,0059 & 0 \\
Escherichia coli (ATCC) & 0,0118 & 0 \\
Staphylococcus haemolyticus & 0,0118 & 0 \\
Pseudomonas aeruginosas (ATCC) & 0,0236 & 0 \\
Salmonella sp. & 0,0236 & 0 \\
Staphylococcus aureus (ATCC) & 0,0946 & 0 \\
\hline 'CIM em mg/mL; & & \\
2Controle Negativo - álcool etanol a 100\%. & & \\
\hline
\end{tabular}

Na literatura não há uma classificação consensual sobre os valores de CIM. PARAGINSKI et al. (2014) testaram a ação antimicrobiana de 15 compostos triazenos e observaram que as melhores ações bacteriostáticas e bactericidas foram impostas pelos triazenos 1,3-bis(fenil-triazeno-1-óxido) e 1(4-fenildiazenil) fenil) -3-(4-carboxifenil) triazeno, ou seja, quando os substituintes hidroxil e carboxil estão presentes. O 1-(4-fenildiazenil) fenil) -3-(4carboxifenil) triazeno foi ativo para todas as cepas Gram-positivas com valores de CIMs entre 16 e $128 \mu \mathrm{g} / \mathrm{mL}$. Os autores atribuíram ao grupo carboxílico substituinte do anel aromático, a influência positiva na atividade frente às cepas Gram-positivas.

O TZC apresentou atividade de espectro reduzido, ou seja, foi ativo em baixas concentrações frente a cepas Gram-positivas e frente a Gram-negativas. A vantagem dos antibióticos de espectro reduzido é que eles podem ser utilizados no tratamento de infecções específicas sem interferir na população bacteriana normal protetora do hospedeiro (MURRAY, 2003).

\section{Il.2.4 Concentração Bactericida Mínima (CBM)}

Os resultados dos testes para determinação da CBM estão sintetizados na Tabela 2. Para a STZC, a menor CBM encontrada foi de 0,0059 para 
Acinetobacter baumannii; para as amostras de Escherichia colie Staphylococcus haemolyticus $0,0118 \mathrm{mg} / \mathrm{ml}$; para Pseudomonas aeruginosa $0,0236 \mathrm{mg} / \mathrm{mL}$ e Staphylococcus aureus a CBM foi de 0,0946. A CBM determina a atividade bactericida ou bacteriostática para estas amostras. Os resultados evidenciaram a importância do composto e de seu uso como alternativa terapêutica, visto que as bactérias testadas apresentam alta prevalência entre as bactérias multirresistentes encontradas em ambiente hospitalar.

Tabela 2. Concentração bactericida mínima in vitro da STZC frente a cepas de referência e isolados clínicos de bactérias

\begin{tabular}{lcc}
\multicolumn{1}{c}{ Microrganismos } & CBM $^{1}$ & CN $^{2}$ \\
Acinetobacter baumannii & 0,0059 & 0 \\
Escherichia coli (ATCC) & 0,0118 & 0 \\
Staphylococcus haemolyticus & 0,0118 & 0 \\
Pseudomonas aeruginosas (ATCC) & 0,0236 & 0 \\
Salmonella sp. & 0,0236 & 0 \\
Streptococcus agalactiae & 0,0473 & 0 \\
Staphylococcus aureus (ATCC) & 0,0946 & 0 \\
\hline 'CBM em mg/mL; & \\
'Controle Negativo - álcool etanol a 100\%; & \\
(-) Não houve crescimento em nenhuma concentração testada. \\
\hline
\end{tabular}

Segundo BLATT et al. (2005), os agentes etiológicos mais comumente isolados das UTIs são, primeiramente, a bactéria Escherichia coli, responsável por aproximadamente $40 \%$ das infecções urinárias dos pacientes hospitalizados e, em segundo lugar, as Pseudomonas aeruginosa, organismos frequentemente encontrados em infecções adquiridas em hospitais, uma vez que a resistência destes aos antibióticos favorece sua seleção em pacientes hospitalizados.

\section{II.2.5 Teste de atividade hemolítica}

A STZC não apresentou atividade hemolítica em baixas concentrações, somente nas concentrações mais altas (Tabela 3). Assim, faz-se necessário o uso de outras técnicas para a confirmação de sua toxicidade.

Tabela 3. Teste de atividade hemolítica in vitro da STZC em hemácia de cavalo e de carneiro

\begin{tabular}{lcc}
\hline & CONCENTRAÇÃO & TITULO \\
SANGUE DE CAVALO & $\mathbf{0 , 0 2 3 6}$ & $(\mathbf{1 : 1 6})^{*}$ \\
SANGUE DE CARNEIRO & $\mathbf{0 , 0 2 3 6}$ & $(\mathbf{1 : 1 6})^{*}$ \\
\hline${ }^{1}$ CMH (Concentração Mínima onde não houve Hemólise) em $\mathrm{mg} / \mathrm{mL} ;$ \\
${ }^{2}$ Controle Negativo - álcool etanol a $100 \% ;$ \\
* Titulo onde não houve hemólise. \\
\hline
\end{tabular}




\section{CONCLUSÕES}

Um composto triazenídico inédito na literatura foi sintetizado e sua estrutura molecular determinada. Os resultados apresentados forneceram novos dados significativos sobre o potencial das atividades biológicas e da química dos triazenos. O TZC apresentou uma atividade antimicrobiana alta, exibindo resultados promissores, com atividade diante de bactérias Gram-positivas, Gram-negativas, apresentando baixos valores de CIM. Apresentou ação bactericida frente a todas as cepas testadas. A atividade hemolítica do TZC foi encontrada somente nas primeiras frações da diluição em tubos com sangue.

Apesar da necessidade de realização de testes confirmatórios adicionais, bem como de novas avaliações da suscetibilidade de outros microrganismos frente ao TZC, os testes iniciais aqui relatados já sugerem um potencial antimicrobiano relativamente elevado deste composto triazenídico.

\section{LEITURA COMPLEMENTAR}

VILLIS, PCM. Tese de Doutorado. Universidade Federal de Santa Maria UFSM, Santa Maria, RS, 2007. Disponível em: http://cascavel.ufsm.br/tede/tde_arquivos/6/TDE-2007-11-27T174224Z1046/Publico/PAULO\%20VILLIS\%201.pdf. Acesso em: 13/12/2017.

\section{AGRADECIMENTOS}

Este trabalho foi apoiado pela Universidade do CEUMA - UNICEUMA e FAPEMA (Processo PROCIENCIA-01788/15). Agradecimento especial ao Professor Dr. Manfredo Hörner pela oportunidade no grupo de pesquisa e as salutares discussões sobre triazenos.

\section{REFERÊNCIAS}

MOORE, D.S.; ROBINSON, S.D.; Adv. Inorg. Radiochem.; 30, 1-68, 1986 CAMBRIDGE CRYSTALLOGRAPHIC DATA CENTRE - CCDC. Banco de Dados. Disponível em: <www.ccdc.cam.ac.uk/conts/retrieving.html>. Acesso em: 14 dez., 2017.

PARAGINSKI, G. L. et al.; Quím. Nova; 37: 7, p. 1138-1144, 2014.

MURRAY, P. R. et al. Manual of clinical microbiology. 8. ed. Washington: ASM Press, 2113, 2003.

BLATT, J. M.; MIRANDA, M. do C.; Ver. Panam. Infectol., 7(4):10-14, 2005. 
KOEHLER, E. G.; Dissertação de Mestrado. Universidade Federal de Santa Maria, 2007.

NEVES, A. P.; VARGAS, M. D.; Rev. Virtual Quim.; v. 3, p. 196-209, 2011.

HARTMAN, W. W; DICKEY, J. B.; Organic Syntheses, Coll. II, 163, 1943.

VERNIN, G.; SIV, C.; METZGER, J.; Synthesis, 691, 1977.

Clinical and Laboratory Standards Institute - CLSI. Disponível em: < http://www.clsi.org/>. Acesso em: 12 dez., 2017.

GOSWAMI, A. K.; PUROHIT, D. N. Anal. Sci., v.17, p.1789-1791, 2001.

HÖRNER, Manfredo et al.; Rev. Bras. Cienc. Farm, v.44, n.3, p. 441-449, 2008. 


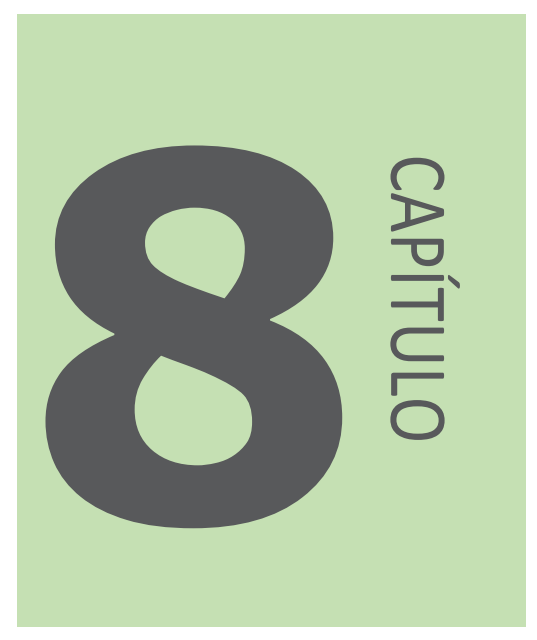

\section{ANÁLISE HIDROLÓGICA SUPERFICIAL DA BACIA DO RIO CURUÇÁ COM URBANIZAÇÃO SUSTENTÁVEL DE TRECHO EM PAÇO DO LUMIAR - MA.}

Neemias Muniz de Souza ${ }^{1}$

Wanderson Pedro Oliveira ${ }^{2}$

Rita de Cássia Mendonça de Miranda ${ }^{3}$

Maria Raimunda Chagas Silva ${ }^{4}$

1;2;3;4 Universidade Ceuma 


\section{RESUMO}

$\mathrm{Na}$ área da bacia do rio Curuçá, as atividades antrópicas têm-se intensificado ao longo das duas últimas décadas, acarretando sérias consequências ambientais, devido à construção de obras de engenharia com níveis diferenciado de interferência na organização do espaço. O leito do rio está sofrendo vários problemas ambientais, devido ao lançamento de efluentes domésticos provocando assoreamento, contaminação e poluição das águas, comprometendo o uso doméstico da água. A avaliação do índice de qualidade da água pode subsidiar a formulação de planos de manejo e gestão de sistemas aquáticos. Nesta pesquisa o objetivo, foi avaliar a qualidade da água do Rio Curuçá, analisando os parâmetros físicos, químicos e microbiológicos da água do rio Curuça, mas conhecido como rio Santo Antônio localizado no município de Paço do Lumiar/MA. O estudo da qualidade analisou os parâmetros físicosquímicos (método de medidas multiparamentro, modelos HANNA) e microbiológicos (método colliteste), com a realização de coletas em cinco pontos distintos no mês de março de 2017 durante o período chuvoso na região. Os parâmetros analisados foram: temperatura da água; turbidez; condutividade; potencial hidrogeniônico $(\mathrm{pH})$; nitrogênio amoniacal $\left(\mathrm{NH}_{4}^{+}\right)$, nitrito $\left(\mathrm{NO}_{2}{ }^{-}\right)$, nitrato $\left(\mathrm{NO}_{3}{ }^{-}\right.$), sólido total dissolvido e coliformes termotolerantes as quais foram realizadas no laboratório de meio ambiente (LACAM) da Universidade Ceuma. Os resultados obtidos nas amostras da água variaram entre $(7,72$ a 7,90$)$ para 0 $\mathrm{pH}$ o que caracteriza alcalinidade, condutividade (123,30 a 165,30 $\mu \mathrm{S} / \mathrm{cm})$; temperatura variou significativamente $\left(27\right.$ a $\left.29^{\circ} \mathrm{C}\right)$; totais de sólidos dissolvidos (61,6 A 89,9); turbidez entre $(20,19$ a 33,48 NTU) NO2- $(>0,01$ a 0,06$)$; NO3$(>0,1$ a 1,4$) ; \mathrm{NH}_{4}+(>0,1$ a 0,8$)$. Observou-se desconformidade com as normas ambientais nos nutrientes e para bacteriologia, todos foram detectados presença de Escherichia coli e bactérias E-colli ou termotolerantes com valor $>1000$ UFC/100 ml. Dados comparados à resolução do CONAMA 357 de 2005. Sendo assim as análises mostram que houve presença de bactérias nas amostras, do grupo Escherichia colli ou termotolerantes ou fecais, os valores encontrados estão acima do permitido de $>1000 \mathrm{NMP} / 100 \mathrm{ml}$ de acordo resolução (CONAMA 357/2005), porém é inadequada para a manutenção da vida aquática. Esta análise possibilitou a verificação da qualidade dessa água, que é de interesse tanto ambiental, quanto socioeconômico da população da região.

Palavras-chave: Bacias Hidrográficas. Maranhão. Sustentabilidade.

\section{INTRODUÇÃO}

O conhecimento sobre a qualidade da água de uma bacia hidrográfica é de extrema importância, pois possibilita inferir sobre as condições da bacia como um todo. Uma forma de se conhecer a qualidade hídrica é fazer o diagnóstico temporal e espacial, obtendo informações necessárias ao gerenciamento e ações de intervenção para recuperação ou preservação dos mananciais, dando melhores condições a sustentabilidade dos ecossistemas (VALLE JUNIOR, 2013). Segundo Souza (2015) a qualidade da água de uma região é determinada 
por processos naturais (intensidade das precipitações, intemperismo, cobertura vegetal) e pela influência antrópica (agricultura, concentração urbana, atividade industrial e uso excessivo da água).

A água representa $70 \%$ da Terra, no entanto, pouco mais de $2 \%$ é doce e está na hidrosfera, disponível para o uso do homem. Designada para diversos fins como culturais, sociais e econômicos. Usada pela indústria e agropecuária por exemplo. De acordo com a ONU, essa quantidade daria para subsistir de forma tranquila, suprindo as necessidades mais simples da população se não coexistisse tanto gasto indevido e poluição. (BORGHETTI; BORGHETTI; FILHO, 2011; SDHILDT et al., 2006; WOLKMER. PIMMEL, 2013

O cenário contemporâneo que prevalece é o de mau uso das águas, proporcionando carência e degradação da sua qualidade, prejudicando a disponibilidade hídrica para recreação, entre outras finalidades. QUEIROZ et al 2010; ALMEIDA, 2013).

No Brasil, a problemática ambiental passa a receber maior atenção a partir de 1930, em função do processo de expansão da agricultura, da urbanização e da revolução tecnológica, que contribuíram para modificações sensíveis da natureza em troca de um ganho econômico imediato, não sendo avaliados o esgotamento dos recursos naturais. Desse modo, observam-se crescentes modificações em todos os ecossistemas, principalmente nas áreas urbanas, onde os efeitos da degradação ambiental são mais intensos.

No que se refere ao território maranhense, a ilha de São Luís dispõe de uma considerável rede de bacias hidrográficas. Porém, os principais rios destas bacias, destacando-se o Anil, o Bacanga e o Paciência, se encontram em estágio avançado de degradação ambiental. Segundo Maranhão (1998:08), os rios da ilha estão em acelerado processo de degradação ambiental, que compromete o abastecimento de água da capital, como é o caso do rio Santo Antônio que inclusive é usado para irrigação de hortaliças e também como manancial subterrâneo, através de uma bateria de poços.

$\mathrm{Na}$ área da bacia do rio Curuçá, as atividades antrópicas têm-se intensificado ao longo das duas últimas décadas, acarretando sérias consequências ambientais, devido à construção de obras de engenharia com níveis diferenciado de interferência na organização do espaço. O leito do rio está sofrendo vários problemas ambientais, devido ao lançamento de efluentes 
domésticos provocando assoreamento, contaminação e poluição das águas, e comprometendo o uso doméstico da água.

Em razão da presença de bactérias coliformes fecais ou termotolerantes, SILVA (2014) indicou que a contaminação da água é devido ao despejo de esgotos domésticos, resíduos de gasolina, lixos e matadouro, uma vez que, há alterações na qualidade da água, devido aos altos níveis de desmatamentos nas margens do rio, causando assoreamento e erosão. Atento ao fato da água se relacionar com a saúde dos habitantes.

De acordo com os autores (BARBOSA E JÚNIOR, 2009) a ausência de investimentos à cidade social resulta no aumento dos desequilíbrios ao ambiente, a destruição dos ecossistemas urbanos, problemas envolvendo as áreas de mananciais, questões relacionadas aos resíduos além das condições de moradia que muitas vezes são em locais insalubres. O planejamento urbano faz-se necessário como tentativa de organizar e propor de forma menos prejudicial os diversos desequilíbrios que ocorrem nas cidades em seus vários processos tanto políticos, econômicos e ambientais.

\section{MATERIAL E MÉTODO}

\section{II.1 COLETA E CARACTERIZAÇÃO DA ÁREA DE ESTUDO}

Foi realizada as coletas em cinco pontos distintos no mês de março de 2017 durante o período chuvoso na região do Paço do Lumiar-MA. Em uma extensão de $21 \mathrm{~km}$ lineares. Sendo P1. nascente, P2. antes da ponte, P3. Depois da ponte, P4. (50m depois da ponte), P5. (100m depois da ponte), P6. (150m depois da ponte).

\section{II.2 INDICE DE QUALIDADE DA ÁGUA}

No Brasil, a maior parte da população é urbana (Silva et al., 2014a; Carmo et al., 2014). Nesse contexto, à medida que a população concentra-se nas cidades, a interferência nos corpos d'água tende a acelerar o processo de degradação hídrica, uma vez que os efluentes domésticos e industriais são as principais fontes de destruição dos mananciais de água doce (Esteves e Menezes, 2011). A urbanização desordenada, pode tornar-se um fator potencial de vulnerabilidade hídrica, uma vez que o crescimento urbano não é 
acompanhado de serviços de saneamento básico (Monteiro et al., 2011 apud DAMASCENO et al 2015).

$\mathrm{Na}$ avaliação da qualidade da água e grau de eutrofização de um corpo hídrico são utilizados Índices de Qualidade da Água (IQA) e Estado Trófico (IET) que determinam a possibilidade de utilização da água para abastecimento público, o enriquecimento por nutrientes e efeito relacionado ao crescimento excessivo das algas ou proliferação de macrófitas (Maier 1987; Esteves 1998; Tavares 2005; CETESB 2006). Segundo a CESTEB (2008), o Índice de Qualidade da Água é uma indicação aproximada do estado de qualidade do corpo hídrico. Para se obter determinação do IQA usa a Equação na figura 1. ANDRIETTI et al, 2015.

$$
I Q A=\prod_{i=1}^{9} Q_{i}^{w}
$$

Figura 1. Equação para obtenção do IQA (Indice de Qualidade da água).

Onde de acordo com ANA (2015), Qi é o valor de qualidade do i-ésimo parâmetro, um número entre 0 e 100, obtido da respectiva curva média de variação de qualidade, em função de sua concentração ou medida. Wi é o peso correspondente ao i-ésimo parâmetro fixado em função da sua importância para a conformação global da qualidade, isto é, um número entre 0 e 1.Cada um dos parâmetros que constitui o IQA possui um determinado peso, relativo à medida da sua contribuição para a qualidade da água (ANDRIETTI et al, 2015).

Segundo Von Sperling (2008), o IQA não é um instrumento de avaliação de atendimento à legislação ambiental, mas de comunicação para o público das condições ambientais do corpo d'água. Sendo calculado pelo produtório ponderado das qualidades de água correspondentes às variáveis que integram o índice (DAMASCENO et al 2015).

Entretanto a qualidade da água é aferida em função do valor de IQA obtido, podendo assim ser de péssima (IQA $<25)$, ruim $(26<\mathrm{IQA}<50)$, regular $(51<$ IQA < 70), boa $(71<$ IQA < 90) ou ótima qualidade $(91<$ IQA $\leq 100)$ ( $\underline{\text { ANA, }}$ 2015 apud ANDRIETTI et al, 2015). Esta qualidade reflete os efeitos agregados de vários processos ao longo do caminho percorrido pela mesma e é influenciada 
pelas características da bacia hidrográfica (MASSOUD, 2012 apud FERREIRA et al, 2015). Portanto, é importante avaliar a qualidade de água para adequá-la ao seu respectivo uso (SINGH; MALIK; SINHA, 2005 apud FERREIRA et al, 2015).

\section{II.3 INDICE DE ESTADO TRÓFICO}

IET (PT) é o índice de estado trófico determinado para o fósforo; IET (CL) é o índice de estado trófico determinado para a clorofila; PT é a concentração de fósforo total medida à superfície da água, em $\mu \mathrm{g} \mathrm{L-1} \mathrm{e;} \mathrm{CL} \mathrm{é} \mathrm{a} \mathrm{concentração} \mathrm{de}$ clorofila a medida à superfície da água, em $\mu \mathrm{g} \mathrm{L-1} \mathrm{(ANDRIETTI} \mathrm{et} \mathrm{al,} \mathrm{2015).}$

Este auxilia na visualização geral grau de trofia (nutrição) e seu efeito na qualidade da água. O IET foi determinado com os resultados de clorofila a (CL) e fósforo total (PT), seguindo o método descrito por Alves et al. (2012). As equações apresentadas na figura 2 foram utilizadas para a determinação do IET.

Figura 2. Equações utilizadas para obtenção do Índice de Estado Trófico.

$$
\begin{aligned}
& \operatorname{IET}(P T)=10 .\left\{6-\left[\frac{0,42-0,36 \cdot \ln (P T)}{\ln (2)}\right]\right\}-20 \\
& \operatorname{IET}(C L)=10 .\left\{6-\left[\frac{-0,7-0,6 \cdot \ln (C L)}{\ln (2)}\right]\right\}-20 \\
& \operatorname{IET}=\frac{\operatorname{IET}(P T)+\operatorname{IET}(C L)}{?}
\end{aligned}
$$

A classificação do ambiente aquático quanto ao IET é dada em seis graus de trofia. Para rios tem-se: ultraoligotrófico (IET $\leq 47)$, oligotrófico $(47<\mathrm{IET} \leq$ 52), mesotrófico (52 < IET $\leq 59)$, eutrófico $(59<\mathrm{IET} \leq 63)$, supereutrófico (63< $\mathrm{IET} \leq 67)$ e hipereutrófico (IET> 67) (ANA, 2015).

\section{II.4 PARÂMETROS FÍSICO-QUÍMICOS}

É fundamental que os recursos hídricos apresentem condições físicoquímicas adequadas para a utilização dos seres vivos, devendo conter substâncias essenciais à vida e estar isentos de outras substâncias que possam produzir efeitos prejudiciais aos organismos (CRUZ et. al. 2007 apud DUTRA et al, 2011). Em cada sistema lótico possui características próprias, o que torna difícil estabelecer uma única variável como um indicador padrão para qualquer sistema hídrico. Neste sentido, a busca em trabalhos de campo é a obtenção de 
índices de qualidade de água que reflitam resumidamente e objetivamente as alterações, com ênfase para as intervenções humanas CRUZ et. al. (2007) citado por FERRAZ et. al. (2009).

Para se determinar as características das águas, foram desenvolvidos vários métodos de analíticos. Estas técnicas foram utilizadas milhões de vezes e se tornaram métodos seguros e confiáveis para se determinar as características físico-químicas e microbiológicas das águas (ESTEVES, F. A., 2011). Estes parâmetros são potencial de hidrogênio (PH), condutividade elétrica, oxigênio e nitrogênio dissolvidos, presença ou não de coliformes para analisar amostras de água como por exemplos água de rio, lagos, mar, agua estuarinas, afluentes etc.

Para o estudo dos parâmetros físicos - químicos utilizou o método de medidas multiparâmetro, modelos HANNA e microbiológicos o método colliteste, com a realização das coletas em cinco pontos distintos no mês de março de 2017 durante o período chuvoso na região.

As variáveis analisadas, assim como os métodos e referências estão apresentados na Tabela 1.

Tabela 1. Parâmetros analisados e seus respectivos métodos.

\begin{tabular}{|l|l|l|}
\hline \multicolumn{1}{|c|}{ Variáveis } & \multicolumn{1}{c|}{ Métodos } & Referências \\
\hline $\begin{array}{l}\text { Temperatura, pH, Turbidez, } \\
\text { Oxigênio Dissolvido, STD, } \\
\text { Salinidade e Condutividade } \\
\text { Elétrica }\end{array}$ & $\begin{array}{l}\text { Equipamento: Multiparâmetro } \\
\text { Hanna instruments HI 93708. }\end{array}$ & APHA, 2005 \\
\hline $\begin{array}{l}\text { Análises Bacteriológicas } \\
\text { Nitrito }\end{array}$ & Teste com o kit COLItest@ & CETESB (2010) SILVA, 2000 \\
\hline Nitrato & Fotômetro & APHA, 2005 \\
\hline Nitrogênio Amoniacal & Fotômetro & APHA, 2005 \\
\hline Fósforo & Fotômetro & APHA, 2005 \\
\hline DBO & Fotômetro & APHA, 2005 \\
\hline DQO & Fotômetro & APHA, 2005 \\
\hline Metais Pesados & Titulação & APHA, 2005 \\
\hline & Espectrofotômetro de & SILVA, 2002 \\
\hline
\end{tabular}

\section{RESULTADOS E DISCUSSÃO}

$\mathrm{O} \mathrm{pH}$ das amostras apresentou-se com variações entre os pontos coletados no mês de março, mas todos enquadrados dentro dos padrões estipulados pela legislação. (P1) 6,82; (P2) 6,93; (P3) 7,00; (P4) 6,90; (P5) 6,93. 
As mudanças na faixa de $\mathrm{pH}$ podem indicar impactos com substâncias ácidas ou básicas capazes de alterar o ambiente químico. Na figura 3, temos as análises

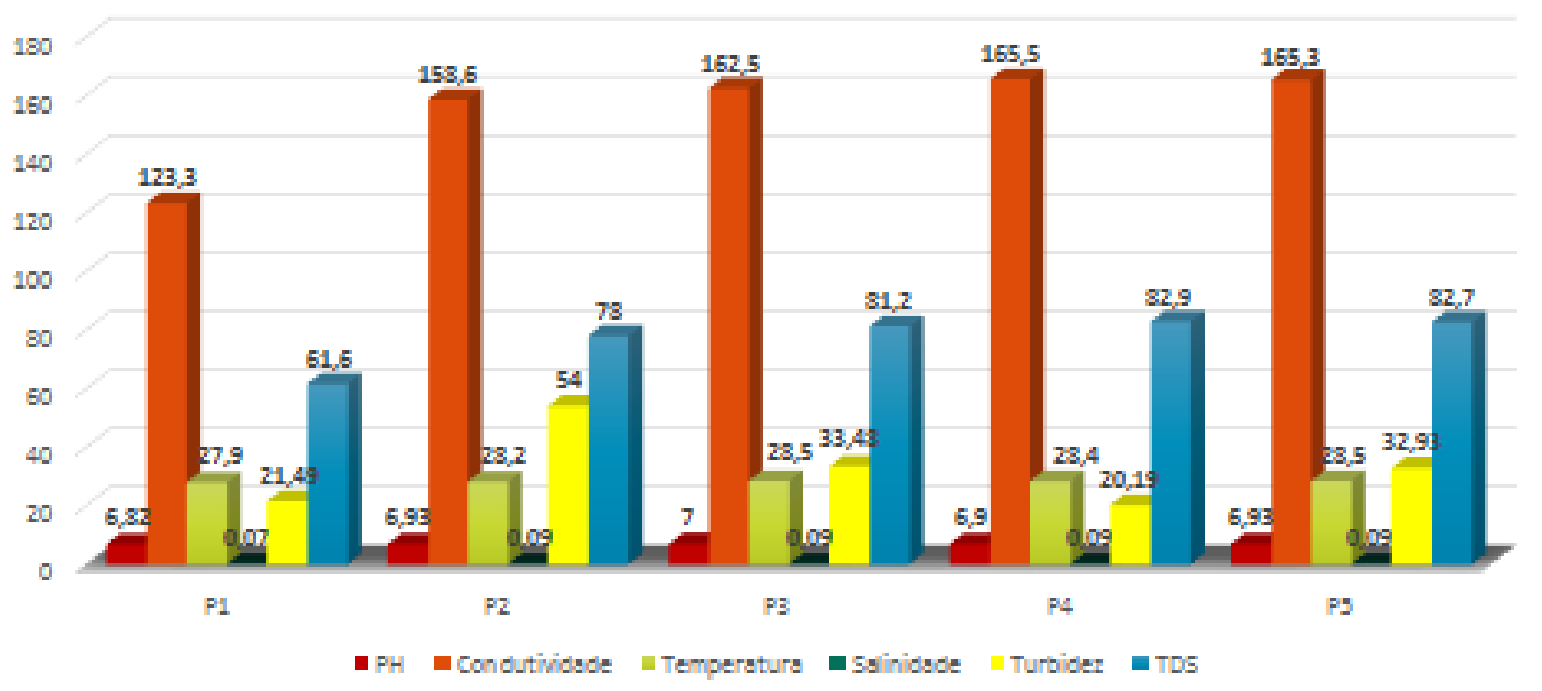

de todos os parâmetros em cada pontos de coleta.

Figura 3. Valores dos parâmetros físico químicos, temperatura, condutividade elétrica, turbidez, pH, Salinidade e STD Em pontos específicos como: P1 - Nascente, P2 - Antes da Ponte, P3 - Entrada da Ponte, P4 - Abaixo da Ponte e P5 -Juçaral.do Rio Curuça no município de Paço do Lumiar no período de março de 2017.

Comparando os valores de condutividade dos pontos coletados no mês de março de 2017, período que marca o início do período intenso de chuva de acordo com o gráfico 1, foram encontradas os seguintes resultados; (P1) 123,3 $\mu \mathrm{S} / \mathrm{cm}$, (P2) 158,6 $\mu \mathrm{S} / \mathrm{cm}$, (P3) 162,5 $\mu \mathrm{S} / \mathrm{cm}$, (P4) 165,5 $\mu \mathrm{S} / \mathrm{cm}$, (P5) 165,3 $\mu \mathrm{S} / \mathrm{cm}$. Observou-se que todos os pontos apresentaram valores acima do limite esperado para águas naturais, recomendado pela resolução CONAMA 357/05, que é de 1 a $100 \mu \mathrm{S} / \mathrm{cm}$.

Os valores encontrados da turbidez foram bastante variados para cada ponto coletado ao longo do rio. (P1) 21,49 UNT, (P2) 54 UNT, (P3) 33,48 UNT, (P4) 20,19 UNT e (P5) 32,93 UNT. A partir desses resultados concluímos que os pontos amostrados apresentam um variação ao longo do rio, porém, devem-se levar em conta as características peculiares de cada ponto. Estes valores estão dentro do limite de turbidez, segundo o CONAMA, que é de 100 UNT.

Os valores de STD observados no mês de março foram entre: (P1) 61,6 mg/L; (P2) 78,0 mg/L; (P3) 81,2 mg/L; (P4) 82,9 mg/L (P5) 82,7 mg/L. Observou- 
se que todos os pontos apresentaram valores dentro do limite esperado para águas naturais, recomendado pela resolução CONAMA 357/05, que é de 500 $\mathrm{mg} / \mathrm{L}$.

A Temperatura do Rio Curuça, apresentou-se com $27,9^{\circ} \mathrm{C}$ no ponto $\mathrm{P} 1$, $28,2^{\circ} \mathrm{C}$ no $\mathrm{P} 2,28,5^{\circ} \mathrm{C}$ P3 e $28,4^{\circ} \mathrm{C}$ no $\mathrm{P} 4$ e $28,5^{\circ} \mathrm{C}$ no P5 em março de 2017 , onde foram registradas no ato da coleta. Esses resultados mostram que os pontos amostrados receberam influências sazonais e acompanharam as flutuações do clima da região; com maiores variações de temperaturas ao longo do seu leito. Entretanto essa variação foi considerada estável.

Na figura 4 os resultados dos valores de nitrato, nitrito, amônia, amônio e cloreto nos pontos de coleta ao longo do rio curuça.

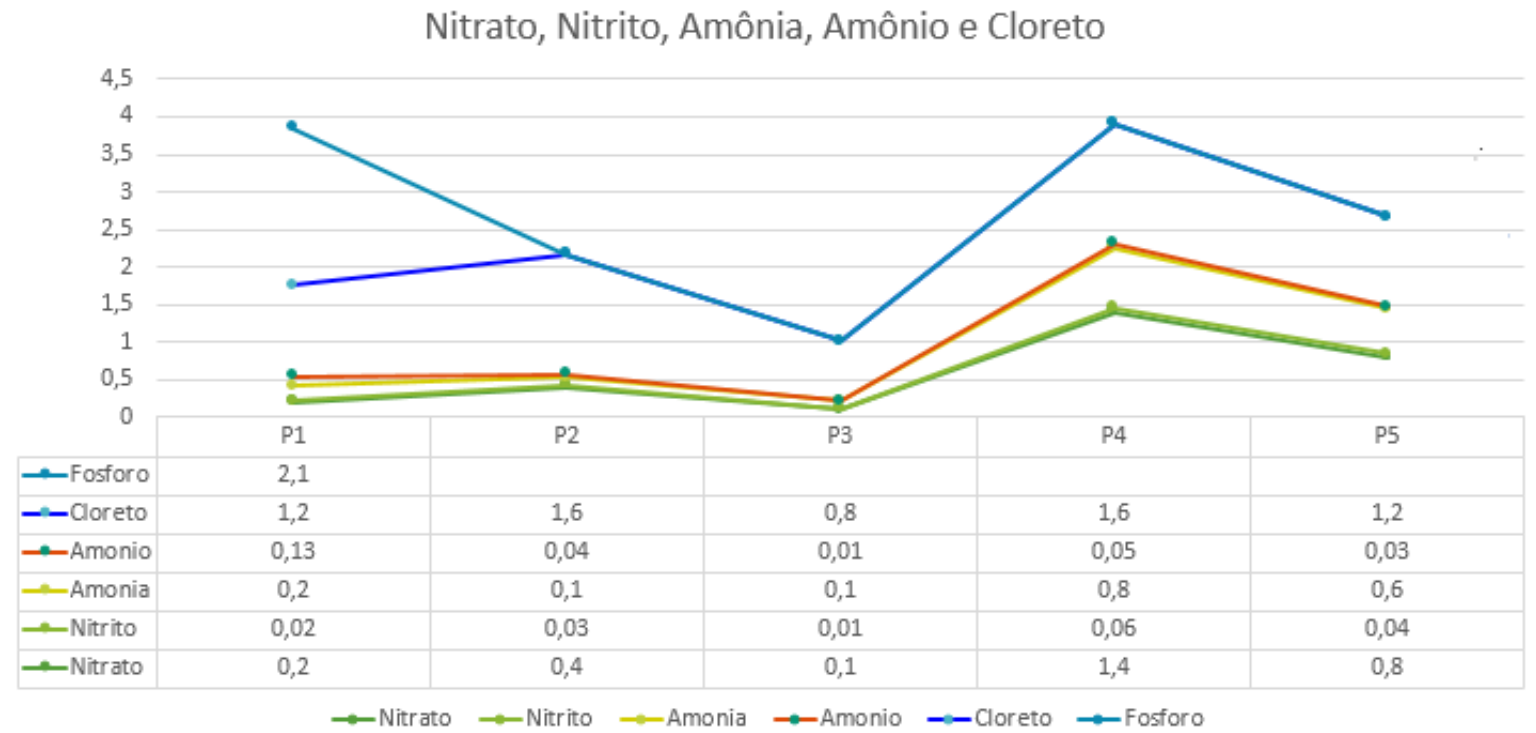

Fígura 4. Determinação de nitrato, nitrito, amônia, amônio e cloreto do Rio Curuçá no município de Paço do Lumiar no período de março de 2017. Em pontos específicos como: P1 - Nascente, P2 - Antes da Ponte, P3 - Entrada da Ponte, P4 - Abaixo da Ponte e P5 - Juçaral.

O Nitrato apresentou as concentrações em todos os pontos amostrais nos mês de março de 2017. O maior valor foi registrado no $\mathrm{P} 4(1,4 \mathrm{mg} / \mathrm{L})$ no período que se inicia o inverno.

O nitrito encontrado em todos pontos apresentaram uma variação moderada entre as amostragens do mês de março, onde se obteve o menor resultado no ponto $\mathrm{P} 3$ de 0,01 mg/L, e um maior valor no ponto P4 de 0,06 mg/L.

Os valores de Amônia encontrados foram: P1 $(0,2)$, P2 $(0,1)$, P3 $(0,1)$, P4(0,6), P5(0.6). Estando dessa forma em todos os pontos acima do nível ideal permitido pela CONAMA 357 que é abaixo de 0,1 mg/L. 
Além disso, sua toxidade segundo a CONAMA aumenta em função do aumento de $\mathrm{pH}$.

Para a bacteriologia, constatou-se a presença de coliformes fecais em todos os pontos amostrais, os resultados obtidos mostram que houve presença de bactérias nas amostras do grupo Escherichia colli ou termotolerantes para todos os pontos de amostragem, como observados na tabela 2.

Tabela 2: Análises de presença de coliforme total e E. coli, em cada ponto: p1nascente, p2-entrada da ponte, p3-abaixo da ponte, p4-meio do rio e p5-no juçaral. no período de março de 2017.

\begin{tabular}{|c|c|c|c|c|c|}
\hline & P1 & $\begin{array}{c}\text { P2 } \\
\text { ENTRADA } \\
\text { DA PONTE }\end{array}$ & $\begin{array}{c}\text { P3 } \\
\text { ABAIXO DA } \\
\text { PONTE }\end{array}$ & $\begin{array}{c}\text { P4 } \\
\text { MEIO DO RIO }\end{array}$ & $\begin{array}{c}\text { P5 } \\
\text { NO JUÇARAL }\end{array}$ \\
\hline $\begin{array}{c}\text { COLIFORMES } \\
\text { TOTAIS }\end{array}$ & POSITIVO & POSITIVO & POSITIVO & POSITIVO & POSITIVO \\
\hline $\begin{array}{c}\text { ESCHERICHIA } \\
\text { COLI }\end{array}$ & POSITIVO & POSITIVO & POSITIVO & POSITIVO & POSITIVO \\
\hline
\end{tabular}

De modo geral, todos os pontos apresentaram altos valores de coliformes totais, o que já era esperado devido a deposição de fezes por animais as margens do açude, a falta de um tratamento para o esgoto doméstico e também devido ao acúmulo de lixo deixado por visitantes.

\section{CONCLUSÕES}

Análises mostram que houve presença de bactérias nas amostras, do grupo Escherichia colli ou termotolerantes ou fecais, os valores encontrados estão acima do permitido de $>1000 \mathrm{NMP} / 100 \mathrm{ml}$ de acordo resolução (CONAMA 357/2005), porém é inadequada para a manutenção da vida aquática. Esta análise possibilitou a verificação da qualidade dessa água, que é de interesse tanto ambiental, quanto socioeconômico da população da região.

\section{LEITURA COMPLEMENTAR}

AMERICAN PUBLIC HEALTH ASSOCIATION- APHA; AMERICAN WATER WORKS ASSOCIATION AWWA; WATER POLLUTION CONTROL FEDERATION. Standard methods for the examination of water and wastewater. Washington D.C., 2005.

CONSELHO NACIONAL DO MEIO AMBIENTE - Resoluções CONAMA. Disponível em:<http://www.mma.gov.br/port/CONAMA/res357/mar/2005.html>. Acesso em: 30 de novembro de 2014. 
ESTEVES, Francisco de Assis, 1950 - Fundamentos de Limnologia - 2. Ed.Rio de Janeiro: Interciência, 2011.

SILVA, da. V. L. caracterização físico - química da água e sedimento do rio pindaré, nos trechos correspondentes aos municípios de pindaré- mirim, tufilândia e alto alegre (ma) 2014. 29f. Monografia (Graduação) Universidade Federal do Maranhão, São Luís, 2014.

\section{AGRADECIMENTOS}

À Deus em primeiro lugar, minha família na pessoa do meu Pai Samuel Batista e minha mãe Arlete Muniz pelo cuidado e ensinamentos, ao Reitor desta Universidade pelo incentivo para que fizesse este mestrado, ao nosso brilhante estagiário Wanderson Pedro pelo empenho e exemplo de estudante, à minha incansável Orientadora Profra. Dra. Maria Raimunda Chagas Silvas pela incrível capacidade de ensinar com maestria e ainda sim caminhar com o mestrando até o alvo almejado mostrando ser capaz e à minha Coorientadora Profra. Dra. Rita de Cássia Mendonça de Miranda pelas dicas, conselhos e ensinos nas horas certas.

\section{REFERÊNCIAS}

AGÊNCIA NACIONAL DE ÁGUAS (Brasil). Índice de qualidades das águas. Portal da qualidade das águas. Brasil, 2009. Disponível em: <http://pnqa.ana.gov.br/ IndicadoresQA/ IndiceQA.aspx> Acesso em: 25 nov. 2015.

ALVES, Igor Charles Castor; EI-ROBRINI, Maâmar; SANTOS, Maria de Lourdes Souza; MONTEIRO, Sury de Moura; BARBOSA, Leandro Patrick Ferreira; GUIMARÃES, José Tasso Felix. Qualidade das águas superficiais e avaliação do estado trófico do Rio Arari (Ilha de Marajó, norte do Brasil).

ANDRIETTI, Grasiane; FREIRE, Rosane; Amaral, Adriana Garcia do; ALMEIDA, Frederico Terra de; BONGIOVANI, Milene Carvalho; SCHNEIDER, Roselene Maria.

Índices de qualidade da água e de estado trófico do rio Caiabi, MT doi:10.4136/ambi-agua.1769. Received: 02 Oct. 2015; Accepted: 30 Nov. 2015

BARBOSA, Gisele Silva (Mestre pelo PROURB/FAU/Universidade Federal do Rio de Janeiro) Endereço eletrônico: giselearquitetura@yahoo.com.br O desafio do desenvolvimento sustentável. Revista Visões 4를 Edção, №4, Volume 1 - Jan/Jun 2008. 
CETESB (2007). Relatório de Qualidade das Águas Interiores no Estado de São Paulo: 2006. São Paulo: CETESB, 2007. (Série Relatórios)

CORTEZ, Lúcia Elaine Ranieri; CAMARGO, Lilian Cristina; OYAMA, Ottoni Jully. Qualidade microbiológica da água para consumo humano em instituição de ensino de Maringá-PR Microbiological quality of human consumption water in a school in Maringa- PR Mirian Ueda Yamaguchi.

Disponível em:

http://www.saocamilosp.br/pdf/mundo saude/106/1827/2017.pdf. Acesso em:

CRUZ, Patrícia; REIS, Layara; BARROS, Aryanne; NEVES, Josyanne; CÂMARA, Flor. Comparativo da qualidade físico-química da água no período chuvoso e seco na confluência dos Rios Poti e Parnaíba em Teresina/PI

DAMASCENO, Maria da Conceição Silva; RIBEIRO, Hebe Morganne Campos; PAULA, Manoel Tavares de. TAKIYAMA, Luís Roberto. Avaliação sazonal da qualidade das águas superficiais do Rio Amazonas na orla da cidade de Macapá, Amapá, Brasil. doi: 10.4136/ambi-agua.1606. Received: 17 Feb. 2015; Accepted: 26 May 2015

DUTRA, Fabrício Martins; FERRAZ, Diego Rogério; HERMES, Cesar Ademar; MACHADO, Waldir Jaccoud; ZANETE, Herbert Rodrigo. Avaliação da qualidade físicoquímica da água no Rio Itapemirim no período chuvoso e seco.

FERREIRA Kássia Crislayne Duarte; LOPES, Fernando Bezerra; ANDRADE, Eunice Maia de; MEIRELES, Ana Célia Maia; Silva, Gerlange Soares da. Adaptação do índice de qualidade de água da National Sanitation Foundation ao semiárido brasileiro. Adapting the National Sanitation Foundation water quality index to the Brazilian semiarid

RIBEIRO Elizene Veloso; MAGALHÃES JUNIOR, Antônio Pereira; HORN, Adolf Heinrich; TRINDADE, Wallace Magalhães. / Geonomos, 20(1), 49-63, 2012. Avaliação da presença de metais pesados e qualidade da água do Rio São Francisco no segmento entre Três Marias e Pirapora - MG: Índice de contaminação.

Disponível em: www.igc.ufmg.br/geonomos. Acesso em:

SILVA, C. M. R. Estudo de Sedimento da Bacia Hidrográfica do Mogi- Guaçu, com ênfase na Determinação de Metais Pesados. 2002. 98f. Dissertação (Mestrado) Instituto de Química de São Carlos, Universidade de São Paulo, São Carlos, 2002.

SILVA, Rita de Cássia Assis da e ARAÚJO, Tânia Maria de. Qualidade da água do manancial subterrâneo em áreas urbanas de Feira de Santana (BA) Groundwater quality in urban áreas of Feira de Santana, State of Bahia. Empresa Baiana de Águas e Saneamento S.A. (EMBASA). 


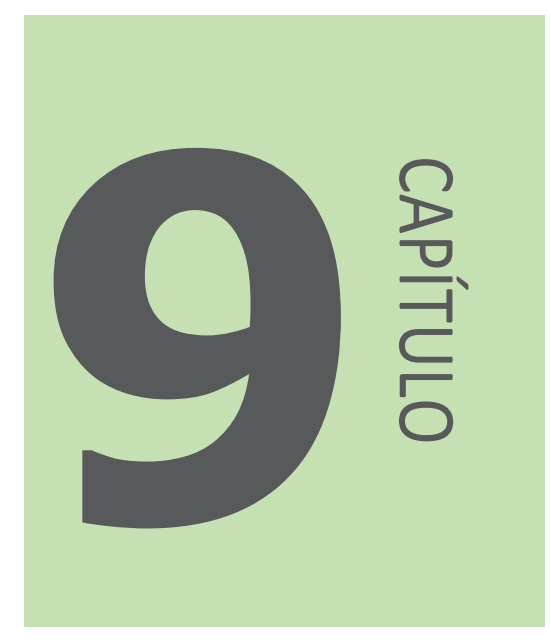

\title{
FREQUÊNCIA DE DOR MUSCULOESQUELÉTICA EM ESTUDANTES DE ODONTOLOGIA - ESTUDO PILOTO
}

\author{
Bruna Katarine Beserra Paz 1 \\ Ariane França Garcês ${ }^{1}$ \\ Miguel Jânio Costa Ferreira ${ }^{1}$ \\ Guilherme Gonçalves Silva² \\ Maria Claudia Gonçalves ${ }^{3}$
}

1;3 Universidade Ceuma Discente do Programa de pós-graduação em Meio Ambiente Uniceuma

${ }^{2}$ Faculdades Integradas da União Educacional do Planalto Central-FACIPLAC 


\section{RESUMO}

Condições ergonômicas e térmicas inadequadas podem contribuir para ineficiência e desconforto no trabalho. Avaliar a frequência de dor musculoesquelética em estudantes do curso de odontologia. Foram inclusos alunos de ambos os gêneros, com idade entre 18 e 30 anos, que já estivessem realizando estágio com atendimento de pessoas há pelo menos 6 meses e foram exclusos aqueles que não respondessem o questionário por completo. 0 questionário Nórdico foi utilizado para avaliar a frequência de dor musculoesquelética. Foram avaliados 20 alunos do $7^{\circ}$ período do curso de odontologia da Universidade CEUMA, com tempo médio de estágio de $7 \pm 3$ meses, com 4 horas de atendimento diário, $60 \%(n=12)$ pertenciam ao gênero masculino, com média de idade de $22 \pm 1$ anos, peso $56 \pm 10 \mathrm{Kg}$ e altura de $1.72 \pm 2$ $\mathrm{cm}$. Foi observado frequência de dor musculoesquelética há pelo menos seis meses em $60 \%(n=12)$ dos discentes, o local com maior queixa de dor foi a região da coluna lombar $80 \%(n=9,6)$, seguida por ombros $50 \%(n=6)$ e coluna cervical $43 \%(n=5)$. Somente $8,3 \%(n=1)$ relatou procurar ajuda profissional para tratar a dor por ter as atividades da vida diária prejudicadas. Cerca de $60 \%(n=12)$. Dos discentes do curso de odontologia que participaram da pesquisa, apresentaram a frequência de dor musculoesquelética alta principalmente nas regiões mais exigidas durante os atendimentos, região inferior das costas, ombros e cervical possivelmente devido a manutenção da postura sentada, os ombros elevados e cervical flexionada durante longo período.

Palavras-chave: Dor muscular. Conforto térmico. Frequência.

\section{INTRODUÇÃO}

Tem havido um esforço crescente nos últimos anos para Investigar as causas dos distúrbios musculoesqueléticos (DMES) e tomar medidas para preveni-los. Fatores relacionados ao ambiente de trabalho estão relacionados ao desenvolvimento de DMES (BUCKLE, 2005).

Os DMES são caracterizados pela presença de desconforto, incapacidade ou dor persistente nas articulações, músculos, tendões e outras partes moles. Sua etiologia é multifatorial que envolve fatores biomecânicos, individuais e psicossociais e que estão relacionados ao trabalho causados ou agravados por movimentos repetitivos, posturas corporais prolongadas, desajeitadas ou forçadas. Os dentistas são normalmente incluídos no grupo de profissionais em risco de sofrer distúrbios musculoesqueléticos, devido a posturas prolongadas inábeis ou forçadas no trabalho e falha em adotar medidas preventivas (HARUTUNIAN et al., 2011). A presença de desconforto, dor persistente em músculos, tendões e articulações são as mais comuns (WOOLF et al, 2003). 
Os sintomas do DMES são devido a movimentos repetidos e posturas corporais inadequadas mantidas de forma forçada por longos períodos de tempo, o que leva a redução da oxigenação dos músculos (MCGILL, 2000), seu impacto não está apenas no âmbito físico mais também afeta os aspectos psicológicos e sociais dos indivíduos (ALEXOPOULOS, 2004; LEGGAT et al, 2007).

Em média, cada pessoa que sofre com DMES perde cerca de 18.9 dias de trabalho, laser ou estudos no período de 12 meses (BUCKLE, 2005), as queixas musculoesqueléticas são a segunda razão mais comum de consulta ao médico, com um total de $10 \%$ a $20 \%$ das consultas relacionadas a cuidados. $\mathrm{A}$ literatura relata forte ligação entre os fatores idade, sedentarismo, tabagismo, obesidade e as disfunções musculo esqueléticas (SZYMANSKA, 2002)

Assim como, as condições ambientais, o conforto ergonômico deve ser observada, uma vez que, pode afetar diretamente as condições musculoesqueléticas reduzindo a produtividade, o rendimento no estudo e no trabalho. O desconforto osteomioarticular é uma queixa comum e implica em muitos gastos médicos e absenteísmo (ANDERSSON, 1999). A presença de desconforto, dor persistente em músculos, tendões e articulações são as mais comuns (WOOLF et al, 2003).

Os sintomas do osteomioarticulares são devido a movimentos repetidos e posturas corporais inadequadas mantidas de forma forçada por longos períodos de tempo, o que leva a redução da oxigenação dos músculos (MCGILL, 2000), seu impacto não está apenas no âmbito físico, mais também afeta os aspectos psicológicos e sociais dos indivíduos (ALEXOPOULOS, 2004; LEGGAT et al, 2007).

O objetivo do estudo foi avaliar a frequência de dor musculoesquelética e o conforto térmico em estudantes do curso de odontologia.

\section{MATERIAL E MÉTODOS}

Foram inclusos alunos de ambos os gêneros, com idade entre 18 e 30 anos, que já estivessem realizando estágio com atendimento de pessoas há pelo menos 6 meses e foram excluídos aqueles que não respondessem o questionário por completo. 
Os sintomas osteomioarticulares foram avaliados por meio do questionário nórdico musculoesquelético (NMQ) acrescentando a escala de intensidade de dor. Segundo Ferrari (2006) NMQ é um dos principais métodos utilizados para avaliar os sintomas osteomioarticulares em circunstâncias ergonômicas e de saúde ocupacional.

O NMQ modificado com intensidade de dor analisa nove regiões: pescoço, ombros, cotovelos, punhos, mãos, parte inferior das costas, quadril, coxas, joelhos, tornozelos e pés, investiga se nos últimos doze meses e últimos sete dias apresentou dor, formigamento, dormência, incapacidades e intensidade de dores nessas regiões (CARVALHO e ALEXANDRE, 2006).

O Conforto térmico foi avaliado através de questionário sobre a percepção da temperatura da sala no momento do atendimento.

\section{RESULTADOS}

Foram avaliados 20 alunos do $7^{\circ}$ período do curso de odontologia da Universidade CEUMA, com tempo médio de estágio de $7 \pm 3$ meses, com 4 horas de atendimento diário, $60 \%(n=12)$ pertenciam ao gênero masculino, com média de idade de $22 \pm 1$ anos, peso $56 \pm 10 \mathrm{Kg}$ e altura de $1.72 \pm 2 \mathrm{~cm}$, foi observado frequência de dor musculoesquelética há pelo menos seis meses em $60 \%(n=12)$ dos discentes (tabela 1).

Tabela 1. Média e porcentagens dos dados demográficos dos alunos avaliados $(n=20)$

\begin{tabular}{lccccc}
\hline & Idade (anos) & Peso $(\mathrm{kg})$ & Altura $(\mathrm{m})$ & $\begin{array}{c}\text { Tempo de } \\
\text { estágio (meses) }\end{array}$ & Dor \% \\
\hline Feminino $(\mathrm{n}=8)$ & $21 \pm 8$ & $54 \pm 9$ & $1,65 \pm 6$ & $7 \pm 3$ & $80 \%$ \\
Masculino $(\mathrm{n}=12)$ & $22 \pm 1$ & $56 \pm 10$ & $1,72 \pm 3$ & & $60 \%$ \\
\hline
\end{tabular}

O local com maior queixa de dor foi a região da coluna lombar $80 \%$ $(n=9,6)$, seguida por ombros $50 \%(n=6)$ e coluna cervical $43 \%(n=5)$ (gráfico 1$)$. 


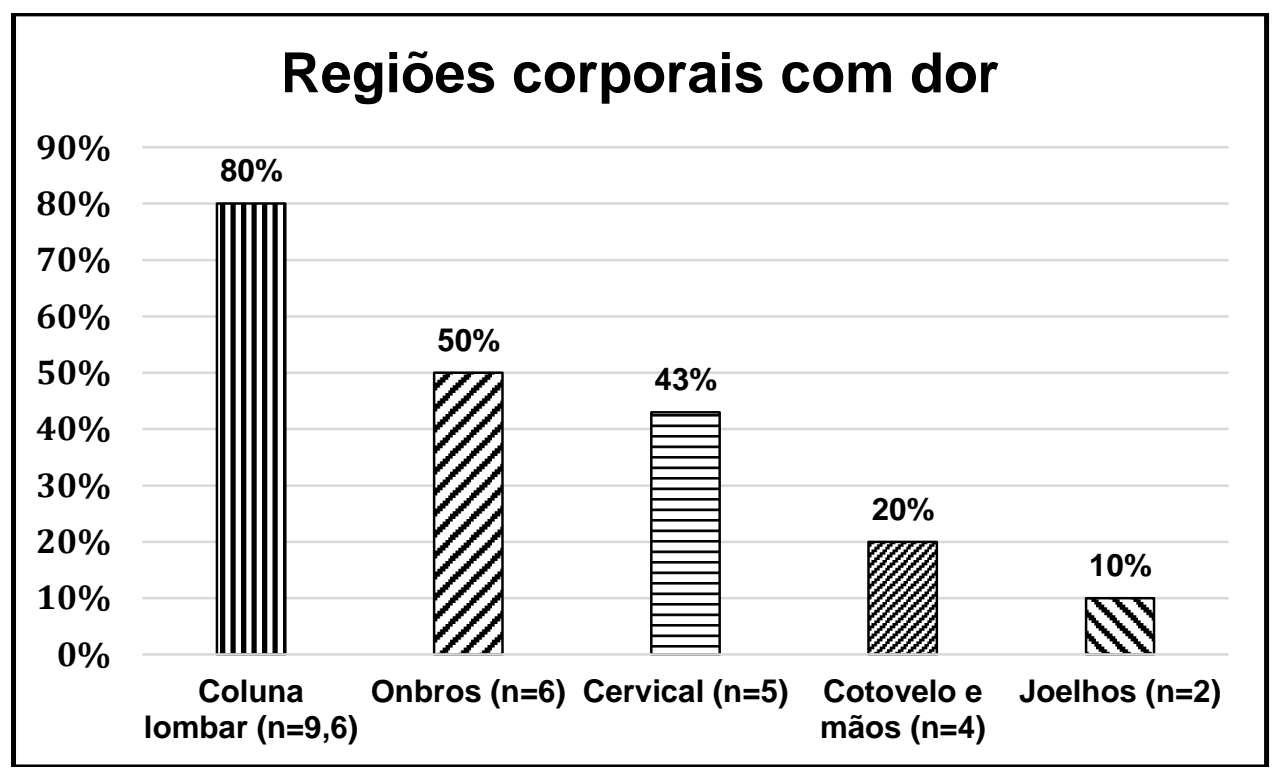

Gráfico 1. Frequência em porcentagens da dor distribuído por regiões corporais $(\mathrm{n}=20)$

Somente $8,3 \%(n=1)$ relatou procurar ajuda profissional para tratar a dor por ter as atividades da vida diária prejudicadas.

\section{DISCUSSÃO}

Por se tratar de estudo piloto, até o momento foram avaliados 20 voluntário do curso de graduação em odontologia. Foi observada maior porcentagem de alunos do gênero masculino. Nossos achados vão ao encontro a literatura que demonstra a predominância do gênero masculino nos cursos de odontologia. Esse fenômeno pode ser explicado, em todo o espectro acadêmico não apenas na graduação mas também na pós-graduação, pela subrepresentadas feminina em campos cujos profissionais acreditam que o talento inato é o principal requisito para o sucesso, além da própria questão cultural onde as mulheres são desencorajadas ao desafio de determinadas profissões (Leslie et al, 2015).

A grande maioria dos alunos apresentou dor em pelo menos uma região do corpo sendo a coluna lombar, ombros e coluna cervical as mais acometidas respectivamente. A dor apresentada nessas regiões pode ser justificada pela própria posição de trabalho seguida pelo volume de horas semanais de estágio.

O cirurgião dentista possui um posto de trabalho pouco ergonômico e se submete a movimentos repetitivos, posturas estáticas e posições que favorecem o aparecimento de sintomas dolorosos no sistema musculoesquelético desde o 
aprendizado. A dor musculoesquelética pode atingir de $63 \%$ a $95 \%$ dentistas (Nasl Saraji et al., 2005) e os acadêmicos odontologia também estão sujeitos a esses fatores e, associado a eles, a falta de experiência que favorece a fixação de vícios posturais relacionados à profissão.

As regiões apresentadas com maior frequência de dor foram coluna lombar, seguida de ombros e coluna cervical, esses dados são semelhantes aos de Sanchez et al, 2015 que observaram $44,5 \%$ de queixas de dor ou desconforto nos membros superiores, $20,4 \%$ nos membros inferiores e $7168,7 \%$ relatos no esqueleto axial. A adoção da postura sentada por um período prolongado, associada com posturas biomecanicamente incorretas, movimentos repetitivos, combinados com a vibração gerada pelos equipamentos/instrumentos e a força estática excessiva oriunda do manuseio dos instrumentos poderiam justificar o surgimento dos sintomas musculoesqueléticos.

A maior prevalência de dor na coluna lombar pode estar relacionada a posição sentada e um dos itens que influenciam diretamente a posição sentada é o tipo do assento. Sendo que o assento convencional oferece uma postura menos adequada e, assim, predispõe os acadêmicos a lesões musculoesqueléticas diversas (Gandavadi et al., 2007). Ainda, O aparecimento de dores parece ser inversamente proporcional ao tempo de experiência profissional em virtude da adaptação e ao treinamento do profissional, o que pode explicar a grande prevalência de sintomas dolorosos nos profissionais recém-formados e não estudantes (Leggat et al., 2006; Rising et al., 2005).

A ferramenta utilizada na atual pesquisa foi o questionário Nórdico, instrumento este difundido e traduzido para várias línguas, sendo utilizado por diversos estudos que visam a avaliação dos sintomas dolorosos, sendo também utilizado por outros estudos que analisaram a presença de dor ocupacional (Almhdawi et al., 2017).

Por fim, este estudo concorda com a afirmação de Sanchez et al, (2015) que enfatiza a necessidade de identificação precoce de sintomas musculoesqueléticos especialmente em profissionais em formação, ou seja, durante a graduação, visto que nesta fase deve ocorrer o aprendizado e a conscientização do acadêmico sobre as causas e consequências das posturas e posições adotadas na sua pratica clínica. 


\section{CONCLUSÃO}

A frequência de dor musculoesquelética dos discentes foi alta principalmente nas regiões mais exigidas durante os atendimentos, região inferior das costas, ombros e cervical possivelmente devido a manutenção da postura sentada, os ombros elevados e cervical flexionada durante longo período. Nossos achados enfatizam a necessidade de identificação precoce de sintomas musculoesqueléticos especialmente em profissionais em formação afim de prevenir o agravamento dos sintomas.

\section{LEITURA COMPLEMENTAR}

O leitor interessado numa revisão dos conceitos básicos sobre o tema aqui proposto, para a correta compreensão dos princípios que fundamentam os procedimentos, sugere-se a leitura da publicação:

Almhdawi, K.A., Mathiowetz, V., Al-Hourani, Z., Khader, Y., Kanaan, S.F.,, Alhasan, M. Musculoskeletal pain symptoms among allied health professions' students: Prevalence rates and associated factors. J Back Musculoskelet Rehabil. 30(6):1291-1301, 2017.

Leslie, S.J., Cimpian, A, Meyer, M, Freeland, E. Expectations of brilliance underlie gender distributions across academic discipli nes. Science. V. 347, p. 262-265, 2015.

\section{REFERÊNCIAS}

Alexopoulos Ec, Stathi Ic, Charizani F. Prevalence of musculoskeletal disorders in dentists. BMC Musculoskeletal Disorders. 5: 16-20, 2004;

Almhdawi, K.A., Mathiowetz, V., Al-Hourani, Z., Khader, Y., Kanaan, S.F.,, Alhasan, M. Musculoskeletal pain symptoms among allied health professions' students: Prevalence rates and associated factors. J Back Musculoskelet Rehabil. 30(6):1291-1301, 2017.

Andersson G.B.J. Epidemiologic features of chronic low back pain. Lancet; 354: 581-85. 1999.

Buckle P. Ergonomics and musculoskeletal disorders: overview. Occupational Medicine; 55: 164-67, 2005.

Carvalho, A. J. F. P; Alexandre, N. M. C. Sintomas osteomusculares em professores do ensino fundamental. Revista Brasileira de Fisioterapia, São Carlos, v. 10, n. 1, p. 35-41, 2006.

Hurutanian K; Garagallo-Albiol J; Figueiredo R; Gay-Escola C. Ergonomics and musculoskeletal pain among postgraduate students and faculty members of the 
School of Dentistry of the University of Barcelona (Spain). A cross-sectional study. Med Oral Patol Oral Cir Bucal. 16 (3):425-429, 2011.

Gandavadi A, Ramsay JRE, Burke FJT. Assessment of dental student posture in two seating conditions using RULA methodology - A pilot study. $\mathrm{Br}$ Dent J.:203(10):601-605, 2007.

Leggat $\mathrm{Pa}$, Kedjarune $\mathrm{U}$, Smith $\mathrm{Dr}$. Occupational health problems in modern dentistry: a review. Industrial health. 45:611-621, 2007.

Leggat PA, Smith DR: Musculoskeletal disorders self reported by dentists in Queensland, Australia. Aust Dent J.;51(4):324-327, 2006.

Leslie, S.J., Cimpian, A, Meyer, M, Freeland, E. Expectations of brilliance underlie gender distributions across academic discipli nes. Science. V. 347, p. 262-265, 2015.

Mcgill S, Hughson R, Parks K. Lumbar erector spinae oxygenation during prolonged contractions; implications for prolonged work. Ergonomics. 2000; 43: 486-93.

Nasl Saraji J., Hosseini, M. H., Shahtahei, S.J., Golbabaei, F.,, Ghasemkhani, M., Evaluation of ergonomic postures of dental professions by REBA. $J$ Dent:;18(1):61-8. 2005.

Rising DW, Bennett BC, Hursh K, Plesh O. Reports of body pain in a dental student population. J Am Dent Assoc.; 136(1):81-86, 2005.

Sanchez, H.M., Sanchez, E.G.M., Filgueira, P.N., barbosa, M.A., Porto, C.C. Musculoskeletal pain in dental students. Rev Bras Med Trab. 13(1):23-30, 2015.

Szymanska J. Disorders of the musculoskeletal system among dentists from the aspect of ergonomics and prophylaxis. Ann Agric Environ Med. 2002; 9: 169-73.

Woolf A. D, Fleger B. Burden of major musculoskeletal conditions. Bulletin of the World Health Organization. 2003; 81: 646-56. 


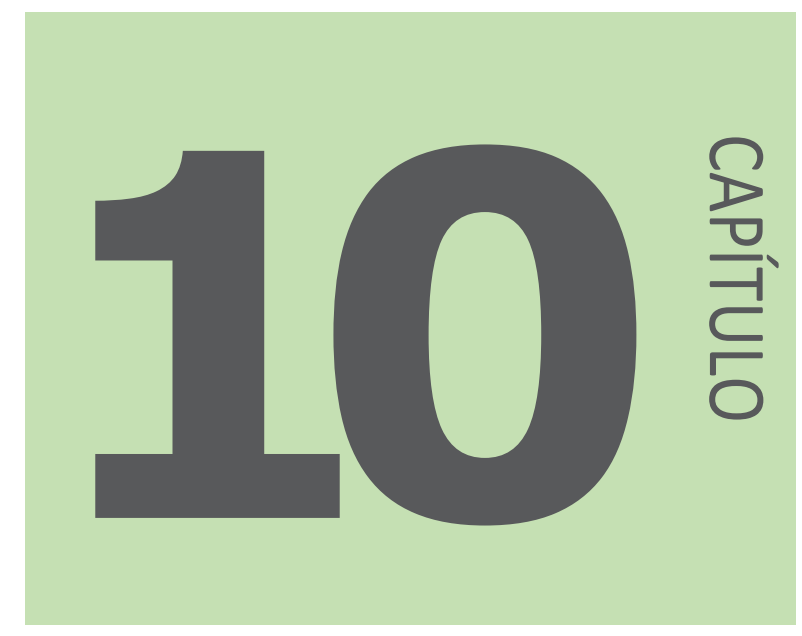

\title{
AVALIAÇÃO DOSIMÉTRICA DE EXPOSIÇÃO OCUPCIONAL EM MEDICINA NUCLEAR
}

\author{
Elsom José Gomes Santos ${ }^{1}$; \\ Alessandra Sampaio Couto'; \\ Wolia Costa Gomes 3
}

1;2;3 Universidade Ceuma 


\section{RESUMO}

$\mathrm{Na}$ área de Medicina Nuclear os trabalhadores ocupacionalmente expostos trabalha com fonte não seladas que emitem radiações ionizantes, apesar do benefício gerado pelo uso das radiações ionizantes, sabe-se que a interação da radiação com a matéria biológica pode produzir efeitos nocivos. Esses têm a probabilidade de receberem doses maiores que o limite anual. Portanto, devem ser monitorados individualmente com dosímetros termoluminescentes usados na parte mais exposta do tórax e avaliado com periodicidade mensal. $O$ trabalho tem como objetivo verificar se as Doses Efetivas Acumuladas (DEA) dos Trabalhadores Ocupacionalmente Expostos, em uma clínica de Medicina Nuclear do Município de São Luís/MA estão de acordo com a normativa NN 3.05 - Requisitos de Segurança e Proteção Radiológica para Serviços de Medicina Nuclear (resolução CNEN 159/13) órgão que regulamenta os níveis de doses aceitáveis no Brasil. É um trabalho descritivo com análise documental dos registros de doses verificados nos 16 (dezesseis) trabalhadores exposto a radiação ionizante referente aos anos de 2015 a 2016. A empresa responsável pelo relatório dos dosímetros termoluminescentes é a TEC-RAD (Tecnologia em Radioproteção LTDA). No presente trabalho, as maiores DEA encontrada foram de 11,75 $\pm 0,10 \mathrm{mSv}$ e $6,32 \pm 0,03 \mathrm{mSv}$, do funcionário identificado como T6 e T11, no ano de 2015 e 2016 da área técnica e a segunda maior dose é observada no profissional da Enfermagem com dose efetiva de 6,28 $\pm 0,11 \mathrm{mSv}$ em 2015, pelo funcionário EF. Concluímos que os trabalhadores que apresentavam maiores valores dosimétricos eram os que atuavam nas áreas de eluição, preparação e administração de radiofármacos, percebe-se que os técnicos e enfermeiro são mais susceptível na área da Medicina Nuclear, mas todos os trabalhadores apresentaram DEA inferior a 20 mSv, por ano, estando em conformidade com a normativa da CNEN NN 3.05.

Palavras-chave: Radioatividade. Medicina do trabalho. Ambiente.

\section{Introdução}

A Medicina Nuclear ( $\mathrm{MN}$ ) é uma especialidade médica que emprega fontes não seladas tanto para fins diagnósticos como tratamento terapêutico. Utiliza-se de substâncias marcadas com radionuclídeos, os radiofármacos, que se concentram em órgãos de estudo, enquanto a radiologia convencional, o ultrassom, a tomografia computadorizada e a ressonância magnética destacam melhor os aspectos morfológicos e anatômicos. (LIRA et al.,2015)

Os princípios básicos de $\mathrm{MN}$ utiliza-se manuseio, produção, posse e a utilização de fontes, bem como o transporte, o armazenamento e segregação de rejeitos. Para isso é necessário garantir a segurança dos Indivíduos Ocupacionalmente Exposto (IOE) que trabalham com radiação ionizante, normatizado e definidos pela norma NN 3.01/14 Diretrizes Básica de Proteção Radiológica da CNEN (Comissão Nacional de Energia Nuclear). 
Dentre várias áreas da medicina, que utiliza a radiação ionizante, a MN é a que deixa os IOE mais susceptíveis a exposição (CNEN-NN-3.05/13). Segundo a Norma CNEN-NN-305 - Requisitos de Segurança e Proteção Radiológica para Serviços de Medicina Nuclear estabelece a limitação de dose individual, essa estabelece que a Dose Efetiva Acumulada (DEA) não poderá passar de $20 \mathrm{mSv}$ ao ano e $4 \mathrm{mSv}$ em qualquer mês. Na região do cristalino $20 \mathrm{mSv}$ ao ano, mãos e pés é de $500 \mathrm{mSv}$ ao ano ou $40 \mathrm{mSv}$ em qualquer mês. Caso supere esse limite, é necessário notificar a CNEN, justificando o ocorrido, descrevendo o evento e a taxa de dose que foi submetido o IOE. (CNEN-NN-305,2013).

Para Oliveira et al (2016), durante a jornada de trabalho, os IOEs ao desenvolverem suas rotinas de manipulação e preparo dos radiofármacos, eliminação dos rejeitos radioativos, contato com pacientes injetados, aquisição de imagens e contaminação de ambientes esses são expostos a diferentes taxas de radiação.

Por esse motivo, tornou-se necessário quantificar as doses para se ter o controle a exposição profissional à radiação. Deve-se executar o monitoramento individual através de dosímetros colocados sobre o corpo. Os dosímetros são instrumentos que indicam a exposição ou a dose absorvida a que um indivíduo foi submetida. (LIRA et al.,2015)

A utilização do dosímetro se faz necessário para estimar a dose efetiva e/ ou da dose equivalente no cristalino e extremidades, em razão da atividade desenvolvida, de modo a demonstrar conformidade com os requisitos administrativo e operacionais estabelecidos pelo serviço, bem como construir para o controle e melhoria da operação da instalação. (ANVISA 453/98).

\subsubsection{Interação da radiação com o tecido biológico}

A correlação entre a exposição à radiação ionizante e os efeitos biológicos induzidos no homem foi estabelecida com dados experimentais após a exposição com doses elevadas, a acidentes radiológicos, às observações nas vítimas de Hiroshima e Nagasaki ou a experiências com cobaias. Os estudos mostraram comparações e confirmações diretas em pacientes submetidos a tratamento de radioterapia ou em experiências em cobaias, onde propositadamente as doses são elevadas. Entretanto, para o estabelecimento com rotina a radiação ionização como no caso a $\mathrm{MN}$, aonde as doses são mantidas duas a quatro ordens de grandeza menores que as anteriormente 
citadas, a observação dos efeitos biológicos fica ofuscada pela ocorrência de muitos outros efeitos, provocados por outros agentes físicos ou químicos, inclusive ambientais.

Segundo Tauhata et al (2013) podemos descrever que os efeitos da radiação dependem da dose, taxa de dose, do fracionamento e do tipo de radiação. As moléculas de DNA podem sofrer um processo de transformação neoplástica. A célula modificada, mantendo sua capacidade reprodutiva, potencialmente, pode dar origem a um câncer. Por consequência das células modificadas, e indução do sistema imunológico devido a multiplicação das células poderá surgir um tumor, num estágio denominado de progressão. Após o período de latência, persistindo a reprodução surge o tumor cancerígeno.

Quando a dose de radiação é elevada o efeito biológico surge em curto intervalo de tempo, denominado efeito determinístico, uma vez que o limiar de dose que as células suportam, foi ultrapassado. As células mais radiosensíveis são as integrantes do ovário, dos testículos, da medula óssea e do cristalino. Nesse tipo de exposição à incidência de catarata, mas também podem ocorrer a esterilidade e as queimaduras de pele.

Mas, há que ressalvar, que situações de valores de pequenas dose podem também induzir efeitos biológicos indesejáveis, como é o caso dos trabalhadores de $\mathrm{MN}$ estes estão em vulnerabilidade a esse efeito chamado estocásticos. Isto significa, que mesmo os trabalhadores com doses pequenas, abaixo dos limites estabelecidos por normas podem induzir efeitos, entre estes se destaca o câncer.

Sendo assim, é importante conhecer os valores de doses a qual está sendo submetido IOE durante o exercício da profissão, afim de reduzir os riscos de danos biológicos causados pela radiação ionizante.

Para Marchior (2015), as doses a que esses profissionais estão expostos sejam medidas de forma precisa e controlada, é necessário o uso de um aparelho individual chamado Dosímetro.

Os Dosímetros Termoluminescente (TLD), esses acumulam a radiação ionizante a qual são expostos e depois no laboratório através de um processo térmico, essa radiação é liberada em forma de fótons, a quantidade de fótons liberados é relativamente a quantidade de dose de radiação ionizante. 
Por isso foram estabelecidos normas e regulamentos para a proteção radiológica, que nesse caso é a portaria ANVISA (Secretaria de Vigilância Sanitária do Município da Saúde) $n^{\circ}$ 453/98 dentre normativa da CNEN 3.01/2014 e 3.05/2013.

Em trabalhos anteriores como: avaliação dosimétrica de Indivíduos Ocupacionalmente Expostos (IOE) em Medicina Nuclear, vigilância de la exposición a radiaciones ionizantes em el personal universitário de la salud e modelo quantitativo de avaliação da contribuição de cada fonte radioativa na dose individual externa $\mathrm{Hx}$ em trabalhador de serviço de medicina nuclear, todos esses trabalhos mostram que os técnicos e enfermeiros foram e estão mais expostos à radiação.

Para verificar a proteção radiológica em uma clínica de Medicina Nuclear no município de São Luís do Maranhão/Brasil, foi avaliada as Doses Efetivas Acumuladas (DEA) dos Trabalhadores Ocupacionalmente Expostos, atendiam os requisitos de saúde ocupacional prescrito pela normativa CNEN NN 3.05 (resolução 159-2013) - Requisitos de Segurança e Proteção Radiológica para Serviço de Medicina Nuclear.

A pesquisa foi descritiva com análise documental dos registros de doses dos trabalhadores exposto a radiação ionizante referente aos anos de 2015 a 2016. A empresa responsável pelo relatório dos dosímetros termoluminescentes empresa TEC-RAD (Tecnologia em Radioproteção LTDA).

Os nomes dos IOE também não são divulgados por questões éticas e acordo firmado com todos. As funções estão classificadas com letra e número para diferenciar cada um dos IOE.

As funções são: Técnicos - T (técnicos e tecnólogos), Enfermeiros - EF, Físicos ( F) e Médico Nuclear - MN

Após análise dos relatórios dos dosímetros dos IOE foram construídas as figuras $1(a, b)$ e $2(a, b)$ referentes a DEA por meses e valor total anual nos anos de 2015 e 2016, os profissionais que apresentaram valores abaixo de 0,20mSv foram excluídos das figuras. 

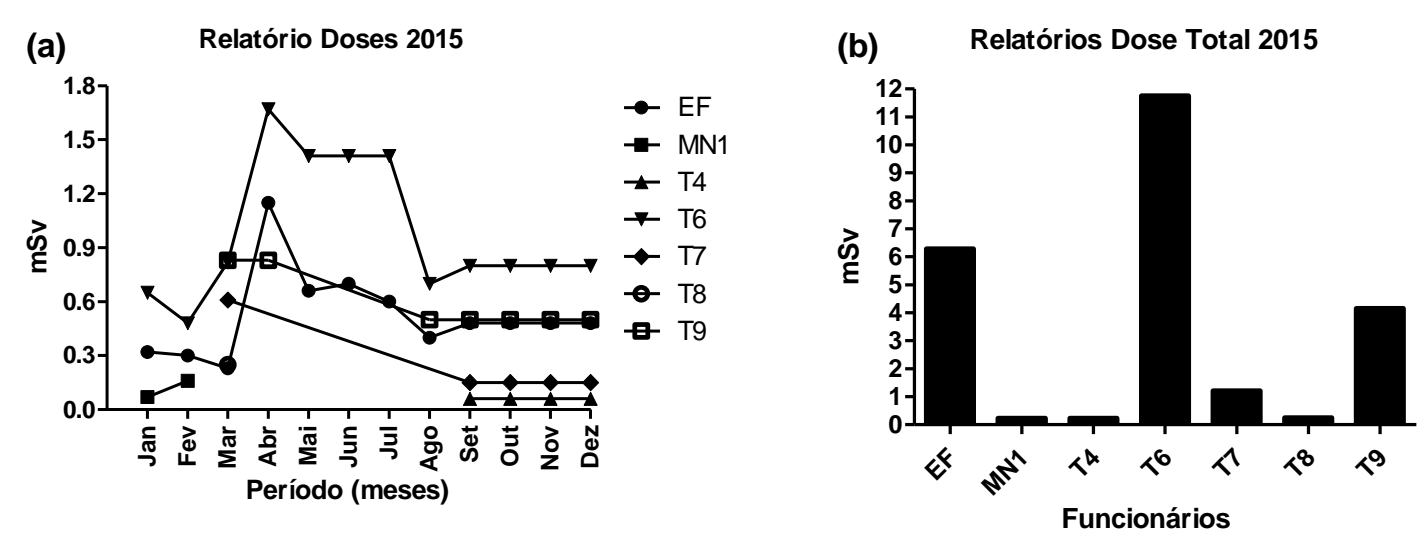

Figura 1 (a,b). Dose efetiva acumulada (mSv) pelos IOE's em 2015. EF=Enfermeiros, MN 1= Médico Nuclear 1 e T = Técnicos.
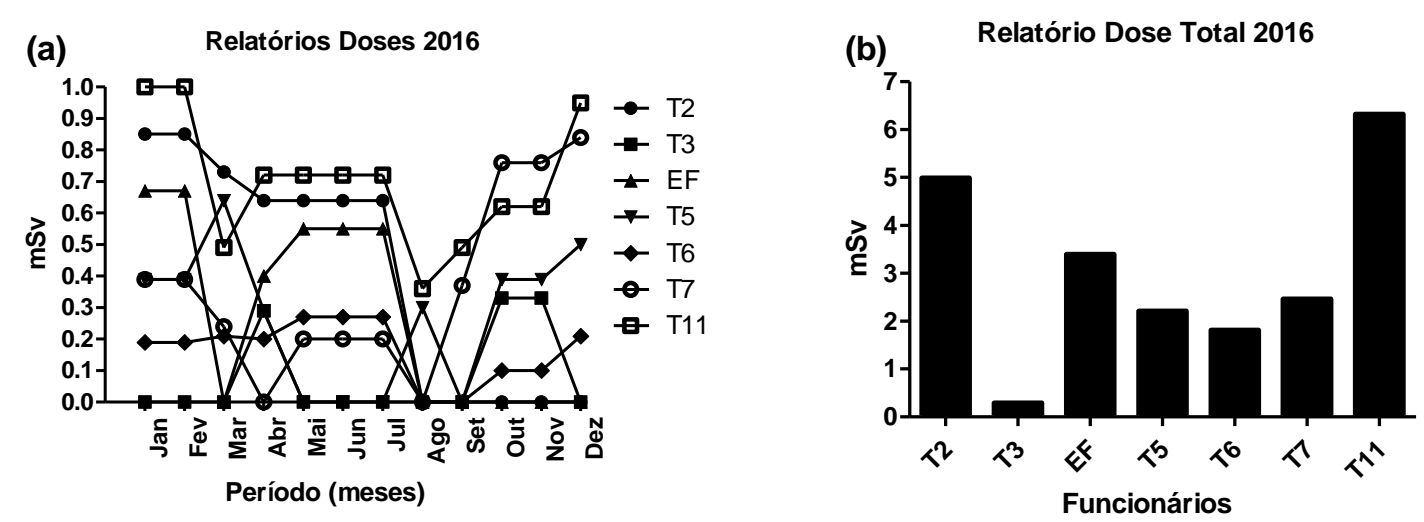

Figura $2(\mathbf{a}, \mathbf{b})$. Dose efetiva acumulada (mSv) pelos IOE's na clínica em 2016. $\mathrm{EF}=$ Enfermeiros, $\mathrm{T}=\mathrm{Té}$ cnicos

Em seguida analisaram-se as doses dos IOE, que estão de acordo com os níveis de dose aceitável pela norma NN 3.01 da CNEN.

Nos estudos de Tomasina et al (2010), os autores mostraram que os setores que recebiam maiores doses em ordem decrescente são: radioterapia oncológica, medicina nuclear, hemodinâmica e radiodiagnóstico. Nesse mesmo trabalho que analisou os dosímetros dos trabalhadores de 2003 a 2006, mostrou que os trabalhadores de Medicina Nuclear também não superaram os limites anuais de referências, mas o desejável seria que os trabalhadores dessa área não fossem expostos a valores de radiação. Sabe-se que mesmo valores de pequenas doses ao longo dos anos podem induzir também os efeitos biológicos como é o caso do efeito estocástico gerado pela radiação ionizante. 
No presente trabalho, a Figura $1(a-b)$ mostra que as maiores DEA de 2015 foram dos funcionários Técnico -T6 de 11,75 \pm 0,10 mSv e Enfermeiro - EF $6,28 \pm 0,11 \mathrm{mSv}$. Nesse ano também percebeu-se que em alguns meses dosímetros registraram valores mensais acima de 1,20 mSv considerado como índice de investigação. Para valores inferiores a 0,20 mSv, a empresa responsável pela leitura dos dosímetros utiliza-se da sigla BG (backgroud), considerando baixa dose de radiação.

O procedimento adotado pela equipe de Medicina Nuclear para proteger os trabalhadores que atingiram o nível de investigação, foi mudar de setor e rotina de serviço. E percebeu-se que nos anos posteriores nenhum IOE estava com dose efetiva elevada no decorrer do mês.

Para o ano de 2016, a Figura $2(a, b)$ mostra que o maior DEA foi para o funcionário Técnico - T11 de 6,32 $\pm 0,03 \mathrm{mSv}$. Em todos os anos, observou-se que havia técnicos com dosimetria elevada em relação aos demais profissionais, mas, isso não significa que seus valores atingiram o limite acima tolerável pela CNEN que é de $20 \mathrm{mSv}$, ou seja, o limite de dose anual para indivíduo ocupacionalmente exposto.

No trabalho de Budecheski et al (2016), o qual foi realizado em duas clínicas de Curitiba (PR), os técnicos também apresentaram maiores DEA em relação aos demais membros da equipe, com valores $16,8 \mathrm{mSv}$.

Um dos motivos para justificar porque esse profissional recebeu maiores dose de radiação é o fato do mesmo fazer a maior parte de rotina na clínica com uso de fontes não seladas, tais como: eluição do gerador de ${ }^{99 m T c}$, preparação dos kits radiofármacos, ou seja, juntar o fármaco com o material radioativo para serem administrados aos pacientes, posicionamento do paciente já administrado com material radioativo para geração da imagem, tempo de permanência na sala de preparo conhecida como sala quente, também tende a aumentar a dose acumulada, devido essa sala ser um dos locais de maiores níveis radiométricos, conforme estudo realizado por OLIVEIRA et al (2016).

Para o grupo dos médicos nucleares, somente o ano de 2015 houve registro de incidência, conforme ilustrado na Figura 4b. A dose maior encontrada foi de 0,23 $\pm 0,04 \mathrm{mSv}$, do Médico Nuclear - MN1. Segundo Budescheski et al (2016), os Médicos Nucleares possuíam doses bem abaixo da equipe Técnica e Enfermagem, o que é justificado pelo fato dos médicos não 
permanecerem na administração dos radiofármacos aos pacientes, e o tempo maior de exposição desses profissionais é às vezes durante os testes ergométricos dos pacientes para realização de exames de miocárdio.

Entre os físicos, não houve nenhum registro nos últimos 2 anos. De fato, esses profissionais não atuam de forma rotineira na sala quente, conforme relato por Oliveira et al (2016) em sua pesquisa a qual mostrou que quanto maior a permanência IOE's, maior será a dose recebida de radiação, sendo está o maior fator de contribuição na dose acumulada.

\section{Conclusões}

De acordo com os resultados obtidos e apresentados, pode-se concluir que:

- Os IOE apresentaram DEA inferior a $20 \mathrm{mSv}$, por ano, estando em conformidade com a normativa da CNEN NN 3.05;

- Os funcionários da função técnica apresentaram a maior DEA, seguindo por Enfermeiro com a segunda maior DEA;

- Os técnicos e enfermeiro são mais susceptível na área da Medicina Nuclear, e requer um monitoramento constante;

- Por medida de radioproteção deve-se fazer um rodízio entre os profissionais de cada área, para minimizar a DEA recebida.

\section{Leitura Complementar}

Análise dos registros de dose ocupacional externa no Brasil, Mauricioa C. L. P., H. L. Silva R. da Silva e Silva C. R. da. Brazilian Journal of Radiation Sciences. v. 3, n. 1, p.01-18, 2015.

\section{Agradecimento}

Os autores agradecem os gestores e funcionários da Clínica de Medicina Nuclear, que forneceram as informações necessárias para o desenvolvimento da pesquisa.

\section{REFERÊNCIAS}

ANVISA - Agência Nacional de Vigilância Sanitária. Resolução RDC n 38, 2008. BUDESCHESKI, S. O; SILVA, F. L; BADELLI, J. C. Avaliação dosimétrica de indivíduos ocupacionalmente expostos (IOE) em Medicina Nuclear. Revista Tecnhoeng, v. 1, n¹3, p. 92-111, 2016.

Comissão Nacional de Energia Nuclear. Diretrizes Básicas de Radioproteção. CNEN-NN-3.01; resolução 2014. 
Comissão Nacional de Energia Nuclear. Requisitos de Radioproteção e Segurança para Serviço de Medicina Nuclear CNEN-NN-3.05; resolução 2013. LIRA R F et al., Verificação do uso de dosímetros individuais em serviço de medicina nuclear de Pernambuco nos anos de 2002 a 2010. Brazilian Journal of Radiation Sciences, p. 26-29, 2015.

Ministério da Saúde - Portaria da Secretaria de Vigilância Sanitária n453 Diretrizes de Proteção Radiológica em Radiodiagnóstico Médico e Odontológico, 1998.

OLIVEIRA et al., Modelo quantitativo de avaliação da contribuição de cada fonte radioativa na dose individual externa $\mathrm{Hx}$ em trabalhador de serviço de medicina nuclear. Brazilian Journal of Radiation Sciences, v. 4, n. 2, p.01-06, 2016.

TAUHATA, L., Salati, I.P.A., DI PRINZIO, R., DI Prinzio, M.A.R.R. Radioproteção e Dosimetria: Fundamento. 9'revisão. Rio de Janeiro, IRD/CNEN, p.111-128, 2013.

TOMASINA, $\mathrm{F}$ et al, Vigilancia de la exposición a radiaciones ionizantes em el personal universitário de la salud. Revista Cubana de Salud Pública. v. 36, n. 1, p. 119-127, 2010. 


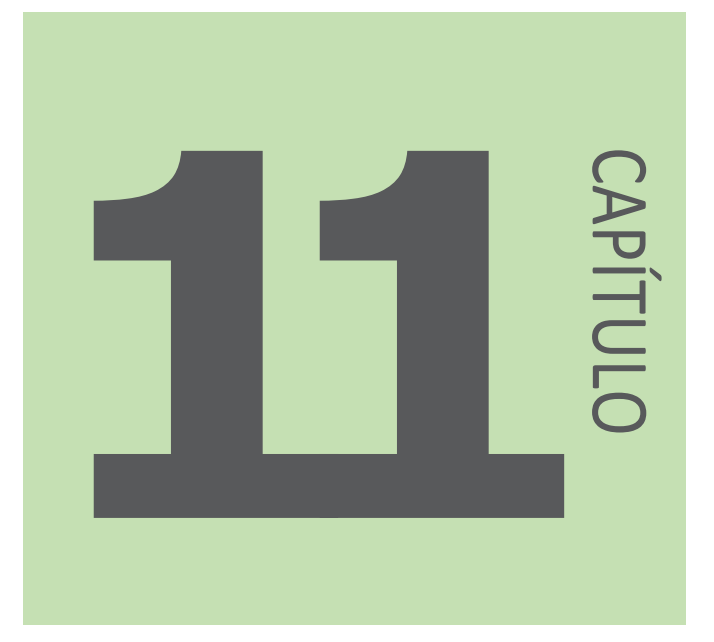

\title{
PREVALÊNCIA DE SENSIBILIZAÇÃO DOS ALÉRGENOS AMBIENTAIS, BLATELLA GERMÂNICA E PERIPLANETA AMERICANA EM PACIENTES ASMÁTICOS
}

\author{
Maryângela Godinho Pereira Bena ${ }^{1}$ \\ Giselmo Pinheiro Lopes ${ }^{1}$ \\ João Lucas do Carmo Lima ${ }^{1}$ \\ Poliana Oliveira Lemos de Brito ${ }^{1}$ \\ Bruna Katarine Beserra Paz ${ }^{1}$ \\ Angela Falcai ${ }^{1}$ \\ 1. Unlversidade CEUMA
}




\section{RESUMO}

A asma vem se tornando um problema de saúde pública nas últimas décadas devido ao aumento na prevalência e morbidade. $O$ seu desenvolvimento está associado a fatores ambientais e genéticos, e depende da predisposição genética para produção de lg E específica para antígenos habituais do meio ambiente. Os fatores ambientais que contribuem são as moradia precárias, poluição ambiental, estressores psicossociais e financeiros, etnia e os alérgenos de baratas, ácaros, fungos. Analisar a prevalência da sensibilização dos alérgenos ambientais, Blatella germânica e periplaneta americana em pacientes asmáticos. A pesquisa foi realizada no pub med com artigos dos últimos 5 anos. Os artigos selecionados explanam sobre a prevalência alérgenos de baratas em pacientes asmáticos. Estudos demonstram que a prevalência da sensibilidade dos alérgenos de Bla g 2 (Blatella germânica) e Per a 9 (Periplaneta americana) são comuns em crianças dos centros urbanos nos Estados Unidos, China, Taiwan, Ásia, Polônia e Brasil. A Blattella germanica é comumente encontrada em climas frio e seco e a Periplaneta americana predominam nas áreas quente e úmida. Ficou evidente que a inalação dos alérgenos de baratas contribui para o desenvolvimento da asma alérgica e que o controle ambiental é benéfico na redução da morbidade e desenvolvimento da asma. Exposições relacionados à fatores ambientais precoces e genéticos específicos, merecem maior atenção para evitar a exacerbação da asma. Controles ambientais são benéficos na melhoria do sintoma de asma e talvez uma estratégia de prevenção viável. Estudos prospectivos de intervenção ambiental são necessários para identificar estratégias para melhorar e prevenir os sintomas de asma.

Palavras-chave: Asma. Ambiente. Baratas.

\section{INTRODUÇÃO}

Asma é uma doença crônica, multifatorial, com fatores genéticos e ambientais envolvidos, na qual participam muitas células e mediadores caracterizada pela hiperresponsividade das vias aéreas, com episódios recorrentes de sibilos, falta de ar, aperto no peito e tosse, particularmente à noite ou no início da manhã.

O termo "asma" não consegue explicar todas as manifestações clínicas observadas nos últimos anos, tem-se levado em consideração às características observadas da interação entre o gene do indivíduo e o ambiente. Dependendo da gravidade e controle da asma, o indivíduo pode ter prejuízos, na escola ou no trabalho, assim como no nível econômico, pois gera custos elevados na área da saúde, em especial na asma grave.

A asma grave corresponde a $50 \%$ dos custos de saúde, se apresenta precocemente na vida e geralmente está associada a condições atópicas. 
Mesmo sendo a forma menos comum da doença, cerca de 5 a $10 \%$ de todos os casos. A Organização Mundial de Saúde estima em 2014 que 334 milhões de pessoas sofrem com asma no mundo, logo se trata de uma doença global. Se a tendência da época se mantiver, existem projeções de aumento para mais de 100 milhões de asmáticos no contingente em 2025. Apesar da progressão no entendimento da fisiopatologia e de crescentes ofertas de tratamento da asma, a taxa de mortalidade permanece elevada com cerca de 250 mil mortes anuais.

No Brasil a asma acomete cerca de 20 milhões de pessoas, os estudos apontam que os sintomas da asma como sibilos, dispneia e tosse recorrente aumentaram $25 \%$ em crianças e adolescentes das grandes cidades brasileiras.

Segundo a Global Initiative for Asthma no ano de 2014, o número de internações por asma no Brasil diminuiu significativamente nos últimos 10 anos, mas permanece sendo uma das cinco causas mais frequentes de internação: 200mil/ano e um custo em torno de 100 milhões/ano nos anos de 2012 a 2014. A taxa de mortalidade no Brasil por asma permanece elevada com média de 2500 mortes/ano (2008-2012) destacando a região Norte que a taxa permanece crescente, enquanto nas outras regiões houve um decréscimo.

Apesar da mudança no panorama epidemiológico com a implantação dos centros e programas de asma terem ajudado na diminuição de internações por asma no Brasil, ainda existe ausência de planejamento em diversas fases (concepção, implementação e manutenção) o que leva ao aumento no número de asmáticos no País nas últimas décadas.

A prevalência da asma no município de São Luís, estado do Maranhão, foi de $19,1 \%$ em um estudo realizado na faixa etária de 13 a 14 anos de idade. O sexo masculino é considerado fator de risco para asma na infância, o que está relacionado em parte ao menor diâmetro e maior tônus das vias aéreas e maiores níveis de lgE observados em meninos. Enquanto na adolescência essa relação se inverte, fica maior para as meninas, o que parece ser decorrente, possivelmente, de fatores hormonais, além de que meninos têm a tendência de subestimar seus sintomas; ao contrário, as meninas podem superestimá-los.

O desenvolvimento da asma está associado a fatores ambientais e genéticos, e depende da predisposição genética para produção de lgE específica para antígenos habituais do meio ambiente. Os alérgenos inalantes no ambiente, são considerados os agentes causais mais frequentes para 0 
desenvolvimento da asma no Brasil. Dentre os grupos de maiores fatores de risco, especificamente, foram encontrados os ácaros da poeira domiciliar (Dermatophagoides pteronyssinus, Dermatophagoides farinae e Blomia tropicalis), os alérgenos de baratas (Periplaneta americana e Blatella germanica), alérgenos de animais domésticos (cão, gato) e de fungos.

Existem aproximadamente 4000 mil espécies de baratas distribuídas pelo mundo, sendo bem adaptadas a uma vasta gama de habitats. A maioria habita em florestas tropicais, apesar da diversidade de espécies, apenas algumas se adaptaram aos ambientes humanos, funcionando como fonte de proteínas que contribuem para o desenvolvimento da asma e de doenças alérgicas.

A presença de teste cutâneo positivo em extrato de barata foi detectado pela primeira vez em Nova lorque por Bernton e Brown em 1964. Desde então, trabalhos vem demonstrando uma bronco constrição após inalação de extrato de barata por pacientes asmáticos e alérgicos, fazendo assim, uma relação causal entre alergia a barata e asma.

A compreensão de alergia a baratas deu-se a partir da clonagem molecular de alérgenos, sendo clonado pela primeira vez o alérgeno de barata bla g 2 no ano de 1995. Desde então, houve a progressão de alérgenos de baratas alemães e americanas

Os efeitos da exposição à alérgenos de baratas incluem produção de IgE específica e teste de sensibilidade em que a morbidade aumenta com a progressão da exposição continua aos alérgenos de baratas. Estudos mostram a relação entre a exposição dos alérgenos de barata com o desencadeamento da asma alérgica, entre eles, houve um estudo marcante de uma associação entre a morbidade da asma e a sensibilização dos indivíduos para os alérgenos, com a exposição destes nas casas de crianças asmáticas.

A detecção destes fatores desencadeantes da asma é fundamental para uma qualidade de vida dos indivíduos asmáticos, pois a redução da exposição depende da identificação e remoção de fatores facilitadores, como restos de alimento, falta de saneamento básico e limpeza, que são vistos como portas de entrada para a morbidade e dificultam o extermínio das baratas

Estratégias para diminuir a exposição ambiental a alérgenos de baratas requerem limpeza extensa, educação e extermínio do inseto. Os alérgenos de 
barata, mesmo após extermínio eficiente, são difíceis de serem removidos do ambiente. Estudar os fatores ambientais ajudam a diminuir as comorbidades envolvidas.

\section{OBJETIVO}

Analisar a prevalência da sensibilização dos alérgenos ambientais, Blatella germânica e periplaneta americana em pacientes asmáticos.

\section{MATERIAS E MÉTODOS}

A pesquisa foi realizada no pub med com artigos dos últimos 5 anos. Os artigos selecionados explanam sobre a prevalência alérgenos de baratas em pacientes asmáticos.

\section{RESULTADOS}

A maioria habita em florestas tropicais, apesar da diversidade de espécies, apenas algumas se adaptaram aos ambientes humanos, funcionando como fonte de proteínas que contribuem para o desenvolvimento da asma e de doenças alérgicas. Apesar da existência de milhares de espécies de baratas, somente 25 adaptaram-se no habitat doméstico e as que predominam são: a barata alemã (Blattella germanica), comumente encontrada em climas frio e seco e a barata americana (Periplaneta americana) predominam nas áreas quente e úmida.

Nos últimos anos muitos alérgenos de barata foram identificados, sequenciados, purificados e produzidos como proteínas recombinantes biologicamente ativas. Estes alérgenos de barata só foi possível ser identificado com o desenvolvimento da clonagem molecular (www.allergen.org). O primeiro alérgeno de barata a ser clonado foi Bla g em 1995 e atualmente, a Bla $g$ possui 10 alérgenos (Bla g 1 - 9 e Bla g 11), Bla g 2 é uma protease aspártica, Bla $g 3$ é uma hemocianina, Bla g 4 é uma calicina, Bla $g 5$ é uma glutathiona Stransferase, Bla $g 6$ é uma troponina C, Bla $g 7$ é uma tropomiosina, Bla $g 8$ é uma miosina, cadeia leve, Bla $g 9$ é uma arginina quinase, Bla $g 11$ é uma alfaamilase. Já a barata Per a contém 10 alérgenos (Per a1-3; Per a 5-7 e Per a 912), sendo a Per a2 é um tipo de protease aspártica, Per a3 é uma arilforinas, 
Per a5 é uma glutathiona S-transferase, Per a 6 é uma troponina $C, P e r$ a7 é uma tropomiosina, Per a 9 é uma arginina quinase, Per a10 é uma serina protease, Per a11 é uma alfa amilase, Per a12 é uma chitinase. A maioria desses alérgenos foram detectados como ligantes de imunoglobulina $E(\lg E)$.

Apesar da existência de diversas espécies de baratas no mundo, a prevalência e sensibilidade dos alérgenos de baratas variam entre as populações e dependem da localização. No Brasil a espécie de barata predominante é a Periplaneta americana, sendo que a reatividade de IgE para Per a 1 varia $9 \%$ no Brasil, enquanto no Taiwan é de $54 \%$ e na Tailândia chega a $100 \%$.

A prevalência da sensibilidade dos alérgenos de Bla g 2 (Blatella germânica) e Per a 9 (Periplaneta americana) são comuns em crianças dos centros urbanos nos Estados Unidos, China, Taiwan, Ásia, Polônia e Brasil. A Blattella germanica é comumente encontrada em climas frio e seco e a Periplaneta americana predominam nas áreas quente e úmida. Ficou evidente que a inalação dos alérgenos de baratas contribui para o desenvolvimento da asma alérgica e que o controle ambiental é benéfico na redução da morbidade e desenvolvimento da asma.

\section{CONCLUSÃO}

A asma vem se tornando um problema de saúde pública nas últimas décadas devido ao aumento na sua prevalência e morbidade, principalmente nas áreas urbanas, sendo este aumento, geralmente associado com o alto grau de sensibilização. A exposição aos alérgenos principalmente os derivados de baratas, são fatores ambientais de grande relevância no agravamento da asma. Por fim, encontramos uma alta prevalência dos alérgenos de barata associado a asma.

\section{REFERÊNCIAS}

ARRUDA, L. K. et al. Clonagem molecular de um alérgeno principal de barata (Blattella germanica), Bla g 2: homologia de sequência com as proteases aspárticas. J Biol Chem, v. 270, p. 19563-19568, 1995.

BARBOSA, M. C. et al. Eficácia de alérgenos recombinantes para o diagnóstico de alergia a baratas em pacientes com asma e/ou rinite. Int Arch Allergy 
Immunol, v. 161, p. 213-119, 2013.

BARRETO, M.L.; RIBEIRO-SILVA, R.C.; MALTA, D.C.; OLIVEIRA-CAMPOS, M.;

ANDREAZZI, M.A.; CRUZ, A.A. Prevalência de sintomas de asma entre escolares do Brasil: Pesquisa Nacional em Saúde do Escolar (PeNSE 2012), Revista Brasileira de Epidemiologia, v.17(1), p.106-115, 2014.

BASSIRPOUR, G.; ZORATTI, E. Cockroach allergy and allergen-specific immunotherapy in asthma: potential and pitfalls. Current opinion in allergy and clinical immunology, v. 14, n. 6, p. 535, dez. 2014.

BERNTON, H.; BROWN, H. Insect allergy: preliminary studies of the cockroach. Journal of Allergy, v. 35, n. 6, p. 506-513, 1964.

BOZZETTO, S. et al. Severe asthma in childhood: diagnostic and management challenges. Current opinion in pulmonary medicine, v. 21, n. 1, p. 16-21, 2015.

BROZOSKI, L.; SILVA, L.G.; SANTOS, A.B.R. Prevalência de alergia para diferentes alérgenos dentre os pacientes asmáticos da cidade de Indaiatuba - SP, Journal of the Health Sciences Institute, v.32(1), p.18-22, 2014.

CAMPO, P. et al. Phenotypes and endotypes of uncontrolled severe asthma: new treatments. J Investig Allergol Clin Immunol, v. 23, n. 2, p. 76-88, 2013.

DO, D. C.; ZHAO, Y.; GAO, P. Cockroach allergen exposure and risk of asthma. Allergy, v. 71, n. 4, p. 463-474, abr. 2016. Disponível em: <https://www.ncbi.nlm.nih.gov/pubmed/26706467>. Acesso em: 25 mar. 2017.

GALOWITZ, S.; CHANG, C. Immunobiology of critical pediatric asthma. Clinical reviews in allergy \& immunology, v. 48, n. 1, p. 84-96, 2015.

GLOBAL INITIATIVE FOR ASTHMA. Global strategy for asthma management and prevention, 2017. Disponível em: <http://www.ginasthma.org $\geq$. Acesso em: 8 abr. 2017.

GRUCHALLA, R. S. et al. Inner city asthma study: relationships among sensitivity, allergen exposure, and asthma morbidity. J Allergy Clin Immunol, v. 115, n. 3, p. 478-485, 2005.

GUILBERT, T. W.; BACHARIER, L. B.; FITZPATRICK, A. M. Severe asthma in children. J Allergy Clin Immunol Pract, v. 2, n. 5, p. 489-500, 2014.

KANG, B. et al. Cockroach as a cause of allergic asthma: its specificity and immunologic profile. J Allergy Clin Immunol, v. 63, p. 80-86, 1979.

KEET, C. A. et al. Bairro, pobreza, residência Urbana, raça/etnia e asma: repensando a epidemia de asma no interior da cidade. $\mathbf{O}$ jornal de alergia e imunologia clínica, v. 135, n. 3, p. 655-662, 2015. 
LIMA, W. L. et al. Asma e fatores associados em adolescentes de 13 e 14 anos em São Luís, Maranhão, Brasil. Cad Saude Publica, Rio de Janeiro, v. 28, n. 6, p. 1046-1056, jun. 2012.

NUNES, C.; PEREIRA, A. M.; MORAIS-ALMEIDA, M. Asthma costs and social impact. Asthma Research and Practice, v. 3, n. 1, p. 1, 2017.

ORGANIZAÇÃO MUNDIAL DA SAÚDE. O relatório global de asma 2014. 2014. Disponível em: <http://www.globalasthmareport.org/burden/burden.php>. Acesso em: 5 abr. 2017.

POMÉS, A. et al. Alérgenos de baratas: função, estrutura e alergenicidade. Protein Pept Lett, v. 14, p. 960-969, 2007.

POMÉS, A.; ARRUDA, L. K. Investigating cockroach allergens: aiming to improve diagnosis and treatment of cockroach allergic patients. Methods, v. 66, n. 1, p. 75-85, 2014.

PORTNOY, J. et al. Environmental assessment and exposure reduction of cockroaches: a practice parameter. Journal of Allergy and Clinical Immunology, v. 132, n. 4, p. 802-808, 2013.

RONCADA, Cristian et al. Asthma treatment in children and adolescents in an urban area in southern Brazil: popular myths and features. Jornal Brasileiro de Pneumologia, v. 42, n. 2, p. 136-142, 2016.

ROSENSTREICH, D. L. et al. The role of cockroach allergy and exposure to cockroach allergen in causing morbidity among inner-city children with asthma. N Engl J Med, v. 336, n. 19, p. 1356-1363, 1997.

ROXO, J.P. et al.. Portuguese-language version of the Asthma Control Test. $\mathbf{J}$ Bras Pneumol., v. 36, n. 2, p. 159-66, 2010.

SHEEHAN, W. J.; PHIPATANAKUL, W. Difficult to control asthma: epidemiology and its link with environmental factors. Current opinion in allergy and clinical immunology, v. 15, n. 5, p. 397, 2015

SILVA, E. C. F.; DIAS, G. A. C. Patogenia da asma. Revista HUPE, Rio de Janeiro, v. 12, n. 2, abr./jun. 2013.

STIRBULOV, Roberto; BERND, Luiz Antônio G.; SOLE, Dirceu. IV Diretrizes brasileiras para o manejo da asma. 2006.

SOCIEDADE BRASILEIRA DE PNEUMOLOGIA E TISIOLOGIA. Diretrizes de doenças pulmonares intersticiais e pulmonares da Sociedade Brasileira de Pneumologia e Tisiologia. J Bras Pneumol, v. 38, s. 2, p. s1-s133, 2012.

SOOKRUNG, N.; CHAICUMPA, W. Uma revisão aos alérgenos da barata. Asian Pac J Allergy Immunol, v. 28, p. 95-106, 2010. 
STELMACH, R. et al. A workshop on asthma management programs and centers in Brazil: reviewing and explaining concepts. J Bras Pneumol, v. 41, n. 1, p. 3-15, 2015.

WANG, J. et al. Effect of environmental allergen sensitization on asthma morbidity in inner-city asthmatic children. Clin Exp Allergy, v. 39, n. 9, p. 13811389, set. 2009.

WENZEL, S. E. Asthma phenotypes: the evolution from clinical to molecular approaches. Nat Med, v. 18, n. 5, p. 716-25, 2012. Disponível em: <http://www.ncbi.nlm.nih.gov/pubmed/22561835>. Acesso em: 2 maio 2017.

$\mathrm{XU}$, L. et al. Cockroach allergen Bla g 7 promotes TIM4 expression in dendritic cells leading to Th2 polarization. Mediators Inflamm, v. 2013, 2013. 


\section{SOBRE OS AUTORES}

\section{Ábia de Jesus Martins}

Bacharel em Biomedicina pela Universidade Ceuma, foi Voluntária do Programa de Iniciação Científica no Laboratório de Microbiologia Ambiental da UNICEUMA, atuando nos seguintes temas: Microbiologia ambiental e processos biotecnológicos.

\section{Alessandra Sampaio Couto}

Graduada em Letras - Português e Inglês pela Universidade Federal do Maranhão. Especialista em Docência do Ensino Superior pela Universidade do CEUMA. Professora da Universidade do CEUMA e Servidora Pública da Secretaria de Educação e Municipal de Educação.

\section{Alessandra Teixeira de Macedo}

Graduada em Biomedicina pela Universidade CEUMA. Possui experiência em Microbiologia com ênfase em Micologia Médica e na avaliação da coinfecção tuberculose/ HIV/ micoses.

\section{Angela Falcai}

Pós-Doutorado em Doenças parasitárias e imunologia das infecções pela Universidade Ceuma, Pós-doutorado em Imunologia básica e aplicada, Universidade de São Paulo, Doutora em Imunologia pela Universidade de São Paulo, mestrado em Imunologia pela Universidade de São Paulo, possui graduação em Ciências Biológicas - Modalidade Médica pelo Centro Universitário de Araraquara, Especialização em acupuntura pelo Colégio Brasileiro de Acupuntura

\section{Ariane França Garcês}

Mestranda do Programa de Pós-graduação em Meio Ambiente e docente do curso de Fisioterapia da Universidade CEUMA. Graduada em Fisioterapia pela Faculdade Santa Terezinha.

\section{Bruna Katarine Beserra Paz}

Mestre em Meio Ambiente pela Universidade CEUMA. Fisioterapeuta, graduada pela Faculdade Santa Terezinha-Cest. Pós-Graduada em Fisioterapia Intensiva e Suporte Ventilatórios pela Faculdade Inspirar, Rio de Janeiro, Especialista em Auditora, Gestão e Planejamento em Saúde pela Faculdade Laboro, São Luís.

\section{Caroline Zilma Kalil de Paula Costa Pereira}

Farmacêutica graduada pela Universidade Ceuma. Durante a graduação, foi aluna de iniciação científica durante três anos, foi Presidente do Centro Acadêmico de Farmácia e membro do NDE.

\section{Celso Henrique Costa}

Mestre em Meio Ambiente, Especialista em Engenharia Ambiental, Bacharel pela UniCeuma, Graduado em Agronomia pela Universidade Estadual do Maranhão. Atua com Saúde Ocupacional na Vigilância Ambiental do Estado do Maranhão. 


\section{Claudson Santos Gomes}

Advogado; Mestre em Meio Ambiente pela Universidade Ceuma; Docente Universitário.

\section{Dagolberto Calazans Araújo Pereira}

Sanitarista; PhD em Saúde Coletiva pela UFMA; Doutor em Saúde Pública pela UFMG; Docente Universitário e Pesquisador há 15 anos.

\section{Denilson da Silva Bezerra}

Doutor em Ciência do Sistema Terrestre pelo Instituto Nacional de Pesquisas Espaciais (INPE). Professor do Mestrado em Meio Ambiente da Universidade Ceuma (UniCeuma) e Consultor Ad Hoc da Fundação de Amparo e Pesquisa e ao Desenvolvimento Tecnológico e Científico do Maranhão (FAPEMA).

\section{Elsom José Gomes Santos}

Graduado em Física Licenciatura pela Universidade Federal do Maranhão. Mestrado em Meio Ambiente pela Universidade do CEUMA. Professor de Física - Secretaria de Educação do Maranhão e professor da Universidade do CEUMA no Curso de Engenharia Civil.

\section{Erima Joyssielly Mendonça Castro}

Graduanda em Engenharia Ambiental pela Universidade do CEUMA UNICEUMA. Integra o grupo de pesquisas de Gestão e Qualidade Ambiental (CNPq). Bolsista da Fundação de Amparo a pesquisa e ao desenvolvimento tecnológico do Maranhão (FAPEMA).

\section{Giselmo Pinheiro Lopes}

Enfermeiro graduado pela Universidade Ceuma. Título de Monitoria em Estrutura Morfo Histológica. Título de primeiro lugar em média no curso de Enfermagem. Especialista em Enfermagem Obstétrica e Neonatal pela Universidade Ceuma. Mestrando em Meio Ambiente pela Universidade Ceuma.

\section{Guilherme Gonçalves Silva Pinto}

Graduado em Medicina pelas Faculdades Integradas da União Educacional do Planalto Central (FACIPLAC) em 2017. Atualmente trabalha na Cidade de Brasília na área de Clinica Geral.

\section{lêda Maria Silva Araújo}

Pós-graduação em Medicina do Trabalho, Saúde Mental e Pericias Médicas e Medicina Legal. Graduada em Medicina e Direito. Residência médica em Cirurgia Geral.

\section{Ingrid Santos Gonçalves}

Graduanda em Engenharia Ambiental pela Universidade do CEUMA UNICEUMA. Integra o grupo de pesquisas de Gestão e Qualidade Ambiental e Pesquisa Química Tecnológica e Ambiental (CNPq). Bolsista da Fundação de Amparo à Pesquisa e ao Desenvolvimento Tecnológico do Maranhão (FAPEMA). 


\section{Ione Cristina Silva de Araújo}

Pós-graduanda em Gestão da Assistência de Enfermagem em Urgência e Emergência (Faculdade Laboro). Graduada em Enfermagem pela Universidade CEUMA,. Possui experiência em Microbiologia com ênfase em Micologia Médica e em resistência cruzada aos antifúngicos.

\section{João Lucas do Carmo Lima}

Graduando em Farmácia Generalista pela Universidade Ceuma. Presidente Discente da Liga Acadêmica de Oncologia da Universidade Ceuma - LACON. Representante Discente do Colegiado do Curso de Farmácia da Universidade Ceuma. Aluno de Iniciação Científica no Laboratório de Microbiologia Ambiental - LAMAM.

\section{Joice Castelo Branco Santos}

Mestranda em Ciências Farmacêuticas pela Universidade Federal do Rio Grande do Norte. Graduada em Biomedicina pela Universidade CEUMA. Possui experiência em Microbiologia com ênfase em atividade antimicrobiana de extratos naturais e compostos sintéticos frente a bactérias.

\section{Jose Costa Sampaio Filho}

Graduado em Química Industrial pela Universidade Federal do Maranhão UFMA (2000), com especialização em Educação e Gestão Educacional pela Escola Alberto Einstein de Ciência e Tecnologia (2015), especialização em Magistério Superior e Mestre em Meio Ambiente pela Universidade do CEUMA UNICEUMA $(2004,2018)$.

\section{Julliana Ribeiro Alves dos Santos}

Doutora em Microbiologia pela Universidade Federal de Minas Gerais, Mestre em Biologia de Fungos pela Universidade Federal de Pernambuco. Graduada em Biomedicina. Atua como docente e pesquisadora dos Programas de Mestrado em Meio Ambiente e em Biologia Microbiana da Universidade CEUMA. Possui experiência em Microbiologia e em Saúde e Meio Ambiente.

\section{Letícia Chagas da Silva}

Mestre em Meio Ambiente pela Universidade CEUMA. Especialista em Enfermagem do Trabalho. Graduada em Enfermagem. Atua como Enfermeira do Instituto Federal do Maranhão (IFMA-Campus Alcântara). Possui experiência em avaliação da modulação dos fatores ambientais nas micoses sistêmicas.

\section{Liene Soares Pereira}

Mestre em Meio Ambiente pela Universidade Ceuma (UniCeuma). Analista Ambiental pela Secretária de Estado de Meio Ambiente e Recursos Naturais (SEMA) do Maranhão.

\section{Luís Claudio Nascimento Silva}

Pós-doutorado financiado pelo Programa Ciências sem Fronteiras (CAPES) na Faculty of Science da University of Copenhague. Doutorado em Ciências Biológicas. Mestrado em Ciências Biológicas Graduado em Biomedicina. Atualmente é Professor da Universidade Ceuma (Uniceuma, São Luís, Maranhão) atuando como Membro Permanente do Programa de Pós-graduação 
em Biologia Microbiana da Uniceuma e Professor do curso de Biomedicina. É Docente permanente do Doutorado em Biodiversidade e Biotecnologia da Amazônia Legal (Bionorte). Leciona(ou) disciplinas na área de Microbiologia, Imunologia, Genética, Biologia Molecular, Bioquímica, e Parasitologia.

\section{Luís Felipe Diniz Pereira}

Graduando em Engenharia Mecânica pela Universidade Federal do Maranhão UFMA. Tem experiência com geotecnologias e gestão ambiental.

\section{Maria Claudia Gonçalves}

Graduada em Fisioterapia pela Pontifícia Universidade Católica (PUC) 2004, doutora pela Universidade de São Paulo, docente do curso de Fisioterapia e do Programa de Pós-graduação em Meio Ambiente e membra do núcleo de pesquisa Mecanismos de modulação de saúde e ambiente no Maranhão.

\section{Maria Raimunda Chagas Silva}

Pós Doutorado na Wageningen University Holanda. Doutorado em Química Analítica pelo Instituto de Química de São Carlos. Mestrado em Química (Química Analítica) Possui graduação em Química Industrial (1999), Formação pedagógica, Licenciatura em Química. Especialização em Educação Ambiental e Recursos Hídrico. Atualmente é Professora e Pesquisadora, (Curso de Ciências da Universidade Federal do Maranhão), Professora do Mestrado Meio Ambiente da Universidade Ceuma e de diversos Cursos de Graduação nas áreas de exatas e saúde. Tem experiência na área de Química, com ênfase em Análise de Traços e Química Ambiental, atuando principalmente nos seguintes temas: água potável, águas subterrâneas, efluente, alimentos, bromatologia, resíduos sólidos e sedimentos, herbicidas, solo, educação ambiental e bacias hidrográficas.

\section{Mariana Santos Costa}

Graduada em Biomedicina pela Universidade Ceuma. Foi bolsista do programa de iniciação científica da Universidade Ceuma. Atuando nos seguintes temas: Microbiologia Ambiental e Ecotoxicologia

\section{Maryângela Godinho Pereira Bena}

Mestre em Meio Ambiente pela Universidade CEUMA. Enfermeira, graduada pela Universidade Ceuma. Especialista em Saúde da Família pela Universidade Estácio de Sá do Rio de Janeiro, Enfermeira do Trabalho pelo Instituto Gianna Beretta, Pós-graduada em Gestão e Docência do Ensino Superior pela Faculdade Laboro.

\section{Miguel Jânio Costa Ferreira}

Graduado em Educação Física, professor Preceptor da Universidade Ceuma, mestrando do Programa de Pós-graduação em Meio Ambiente desta mesma universidade e membro do Núcleo de Pesquisa Mecanismos de modulação de saúde e ambiente no Maranhão/CEUMA/CNPQ

\section{Neemias Muniz de Sousa}

Mestre em Meio Ambiente. Possui graduação em Arquitetura e Urbanismo pela Universidade Ceuma (2013). Atualmente é prefeito da Universidade Ceuma. 
Tem experiência na área de Arquitetura e Urbanismo, com ênfase em Projeto de Arquitetura e Urbanismo.

\section{Patrícia de Maria Silva Figueiredo}

Doutora em Ciências Biológicas (Microbiologia) pela Universidade de São Paulo. Mestre em Ciências Biológicas (Microbiologia) pela Universidade de São Paulo. Possui graduação em Farmácia Bioquímica pela Universidade Federal do Maranhão. Atualmente é professora adjunta da Universidade Federal do Maranhão - UFMA no Departamento de Farmácia, disciplina Microbiologia Clínica e Controle de Qualidade Microbiológico de Medicamentos e Cosméticos. Tem experiência na área de Patogenicidade, com ênfase em Microbiologia, atuando principalmente nos seguintes temas: bacilos Gram negativos fatores de virulência bacterianos (hemolisinas, citotoxinas, formação de biofilme, atividade enzimática, adesão) e atividade biológica de extratos vegetais com potencial antimicrobiano e/ou antivirulência.

\section{Paulo Cesar Mendes Villis}

Doutor e Mestre em Química Inorgânica pela Universidade Federal de Santa Maria. Professor da Universidade do CEUMA - UNICEUMA e coordenador adjunto do Mestrado em Pós-Graduação em Meio Ambiente e Graduação em Engenharia Ambiental. É graduado em Química Industrial pela Universidade Federal de Santa Maria (2001), graduado em Química - Licenciatura Plena pela Universidade Federal de Santa Maria e pós-graduação na Universidade Federal de Alfenas - UNIFAL/MG. (Tem experiência na área de Química, com ênfase em Química de Coordenação, Cristalografia e Eletroquímica, atuando principalmente nos seguintes temas: síntese inorgânica, novos materiais, química de estado sólido, química ambiental, química medicinal, polimorfismo de fármacos e complexos de coordenação.

\section{Poliana Oliveira Lemos de Brito}

Formada em História pela UEMA- Universidade Estadual do Maranhão. Graduanda em Farmácia pela universidade Ceuma. É aluna de iniciação científica pela Fundação de Amparo à Pesquisa e ao Desenvolvimento Científico e Tecnológico do Maranhão- FAPEMA no laboratório de microbiologia ambiental- LAMAM. Foi membro da liga de imunologia em 2017/2018. Presidente e fundadora da Liga Acadêmica de Oncológia.

\section{Queren Hapuque da Silva Costa}

Graduada em Biomedicina pela Universidade Ceuma. Foi bolsista do programa de iniciação científica da Universidade Ceuma. Atuando nos seguintes temas: Microbiologia Ambiental e Biotecnologia.

\section{Raoni B.Tomaz}

Engenheiro Florestal e Mestre em Meio Ambiente pela Universidade Ceuma (UniCeuma). Consultor ambiental, atuando na temática de gestão ambiental e de uso e ocupação relacionadas ao Cadastro Ambiental Rural (CAR).

\section{Rita de Cassia Mendonça de Miranda}

Doutora em Biologia de Fungos pela UFPE. Mestre em Biotecnologia de Produtos Bioativos pela UFPE. Possui graduação em Ciências Biológicas 
especialização em biotecnologia e mestrado em Biotecnologia de Produtos Bioativos. Tem experiência na área de microbiologia, com ênfase em Biotecnologia. Realizou o pós doutoramento como bolsista do programa PNPD na Universidade Federal de Sergipe e no Instituto Tecnologia e Pesquisa (ITP), da Universidade Tiradentes desenvolvendo projetos na área de Biotecnologia e Bioprocessos. Atualmente é professora da Universidade Ceuma, vinculada ao mestrado de Meio Ambiente e aos cursos de graduação em Engenharia Ambiental e Fisioterapia. Pertence ao quadro de professores permanente do Doutorado em Rede de Biodiversidade e Biotecnologia da Amazônia Legal atuando com pesquisas na área de Biorremediação, Tratamento de Resíduo e Investigação de Compostos Bioativos.

\section{Rodrigo Vieira Blasques}

Formado em Metalurgia pelo Instituto Federal de Ciência e Tecnologia do Maranhão (2015) com competências que atendem às exigências na área de siderurgia, metalurgia, mineração, fundição e soldagem. Graduando em Química Industrial pela Universidade Federal do Maranhão - UFMA. Atualmente é membro do grupo de pesquisa Química Tecnológica e Ambiental (Universidade do CEUMA - UNICEUMA) e do Núcleo de Análises de Resíduos de Praguicidas - NARP (UFMA), principalmente nas seguintes áreas: Química Ambiental, Materiais e Eletroquímica.

\section{Sielys dos Santos Amaral}

Graduanda em Engenharia Ambiental pela Universidade do CEUMA UNICEUMA. Tem experiência na área de Engenharia Sanitária, com ênfase em Engenharia Ambiental. Pesquisadora de Iniciação Científica voltadas a Qualidade e Análises de águas e Análises microbiológicas da Qualidade do Ar de Ambientes Internos.

\section{Thalison Rômulo Rocha Araujo}

Bacharel em Biomedicina pela Universidade Ceuma com habilitação em Patologia Clínica, registrado (no 09408) pelo Conselho Regional de Biomedicina $2^{\circ}$ região; foi Voluntário do Programa de Iniciação Científica no Laboratório de Microbiologia Ambiental da UNICEUMA, atuando nos seguintes temas: Microbiologia ambiental e processos biotecnológicos.

\section{Thayná Fernandes Barros}

Farmacêutica, graduada pela Universidade Ceuma (2013-2017). Tem experiência na área de Microbiologia, atuando no estudo da patogenicidade bacteriana em modelo experimental in vivo alternativo. Participou de projetos voltados para Caracterização e Mecanismos de Ação de Compostos Bioativos e Farmacologia de Produtos Naturais. Atualmente, aluna especial do Programa de Pós-Graduação em Biociências-PPGBio pela UFCSPA.

\section{Viviane Gomes Brito}

Mestre em Meio Ambiente pela Universidade Ceuma (UniCeuma). Professora do curso de Direito da UniCeuma e promotora de meio ambiente no município de São Luís (MA). 


\section{Wanderson Pedro de Oliveira Carvalho Araújo}

Graduando de Engenharia Civil, Aluno pesquisador bolsista, atividades realizadas nas áreas ambientais, trabalhos publicados em anais na área de águas subterrâneas, atividades laboratoriais de meio ambiente, atividades em estudos nas áreas geotécnicas.

\section{Wellington de Sousa Monteles}

Mestre em Meio Ambiente pela Universidade Ceuma, possui graduação em Engenharia Elétrica pela Universidade Federal do Maranhão (2004). Tem experiência na área de Engenharia Elétrica, com ênfase em Sistema de energia. Possui também especialização em Engenharia de Segurança do Trabalho pela Universidade Estadual do Maranhão (UEMA) e atualmente é Professor do Instituto Federal de Educação, Ciência e Tecnologia do Maranhão (IFMA) Campus Bacabal.

\section{Wolia Costa Gomes}

Doutora em Engenharia de Processos pela Universidade Federal de Campina Grande. Mestrado em Engenharia Agrícola. Graduada em Química Industrial pela Universidade Estadual da Paraíba. Professora e Pesquisadora do Programa de Mestrado em Meio Ambiente, do Curso Engenharia Civil e do Curso Tecnologia em Gastronomia da Universidade do CEUMA. 